\author{
UNIVERSIDADE DE SÃO PAULO \\ FACULDADE DE ODONTOLOGIA DE BAURU
}

\begin{abstract}
CARGA IMEDIATA SOBRE IMPLANTES OSSEOINTEGRÁVEIS PARA ANCORAGEM ORTODÔNTICA: ESTUDO EM MINIPIGS
\end{abstract}

PAULA VANESSA PEDRON OLTRAMARI-NAVARRO

Bauru

2008 



\section{CARGA IMEDIATA SOBRE IMPLANTES OSSEOINTEGRÁVEIS PARA ANCORAGEM ORTODÔNTICA: ESTUDO EM MINIPIGS}

Tese apresentada à Faculdade de Odontologia de Bauru, da Universidade de São Paulo, para obtenção do título de Doutor em Odontologia.

Área de Concentração: Ortodontia

Orientador: Prof. Dr. José Fernando Castanha Henriques

Bauru 
Oltramari-Navarro, Paula Vanessa Pedron

Ol8c Carga Imediata sobre implantes osseointegráveis para ancoragem ortodôntica: estudo em minipigs. / Paula Vanessa Pedron Oltramari-Navarro. - Bauru, 2008

177p. ; il. ; 30cm

Tese. (Doutorado) - Faculdade Odontologia de Bauru. USP.

Orientador: Prof. Dr. José Fernando Castanha Henriques

Autorizo, exclusivamente para fins acadêmicos e científicos, a reprodução total ou parcial desta tese, por processos fotocopiadores e outros meios eletrônicos.

Assinatura do autor:

Data:

Projeto de pesquisa aprovado pela Comissão de Ética no Ensino e Pesquisa em Animais (CEEPA) da Faculdade de Odontologia de Bauru, Universidade de São Paulo, em 15 de dezembro de 2006 processo no 21/2006. 




\section{Paula Vanessa Pedron Oltramari-Navarro}

Nascimento 07 de Janeiro de 1980

Naturalidade Palotina- $P R$

Filiação Altamir Armando Oltramari

Arlete Pedron Oltramari

1998-2001 Curso de Graduação em Odontologia na Faculdade de Odontologia de Bauru, Universidade de São Paulo (FOB-USP)

1999-2001 Iniciação Científica na Disciplina de Anatomia da Faculdade de Odontologia de Bauru, Universidade de São Paulo (FOB-USP)

2002-2002 Aperfeiçoamento em Ortodontia pela ACOPEN - Assessoria e Consultoria de Ortodontia, Pesquisa e Ensino

2003-2005 Curso de pós-graduação em Ortodontia ao nível de Mestrado na Faculdade de Odontologia de Bauru, Universidade de São Paulo (FOB-USP)

2005-2008 Curso de pós-graduação em Ortodontia ao nível de Doutorado na Faculdade de Odontologia de Bauru, Universidade de São Paulo (FOB-USP)

2008-atual Professora de Ortodontia da Universidade Norte do Paraná (UNOPAR)

Associações Sociedade Brasileira de Pesquisa Odontológica(SBPqO) International Association for Dental Research (IADR) 

“Bom mesmo é ir à luta com determinação. Abraçar a vida e viver com paixão. Perder com classe e vencer com ousadia, pois o triunfo pertence a quem se atreve. A vida é muito para ser insignificante."

"A persistência é o caminho do êxito."

Charles Chaplin 



\section{AGRADECIMENTOS}

Agradeço a Deus por ter me abençoado com uma família maravilhosa e com amigos especiais. Por ter permitido que eu vivenciasse este momento tão especial e gratificante da minha vida profissional.

Obrigada senhor, por estar sempre presente em todos os momentos da minha vida, guiando-me por caminhos retos e iluminando-me na realização deste trabalho.

Eu lhe agradeço pela missão que me confiou, e lhe ofereço os frutos de meu trabalho. Quero celebrar a formação de cada aluno, realizar o tratamento de cada paciente, na felicidade de ter aberto um longo caminho. Exaltar as minhas conquistas sem esquecer-me do esforço que me fez crescer e evoluir. Renovar a cada dia a coragem de sempre recomeçar.

Senhor! Inspira-me na minha vocação. Dá-me paciência e humildade para servir, procurando compreender profundamente as pessoas que a mim confiaste. 



\section{DEDICATÓRIA}

Aos meus queridos pais, Arlete e Altamir, com quem aprendi as mais belas lições de amor, carinho e dedicação. Agradeço por todo incentivo e apoio nos momentos e decisões mais importantes da minha vida, muitas vezes, abdicando de seus sonhos para que eu pudesse realizar os meus. Considero-os exemplo constante em minha vida de esforço e honestidade. A vocês devo tudo, meu equilíbrio, minha formação profissional, minhas virtudes morais e espirituais. Não tenho palavras para expressar o imenso orgulho por tê-los como meus pais. Eu amo vocês!

Ao meu querido esposo, Ricardo, com quem divido diariamente trabalho, idéias, alegrias, preocupações, erros e acertos. Seu companheirismo, perseverança, paciência, inteligência e, sobretudo, seu amor tornaram este sonho realidade. Somente nós sabemos o que se passou até chegarmos aqui, mas apesar das dificuldades, permanecíamos sempre unidos, e cada um dos inúmeros desafios enfrentados aumentaram nossa cumplicidade. Que juntos, possamos continuar a escrever a história de nossas vidas, repleta de felicidade e amor. Divido com você a autoria deste trabalho!

Aos meus queridos irmãos, Ana Cristina e Marcos Roberto, pelos fortes laços de amor e carinho que nos unem cujas doces lembranças funcionam como um bálsamo, amenizando a saudade. Agradeço pelo estímulo constante, fortalecendome na busca de meus ideais.

À minha sogra Fidela, a quem considero uma segunda mãe, pelo amor e carinho com que sempre me recebeu. Temos uma grande amizade e muitas afinidades. Sempre presente e atenciosa, é incansável em nos mostrar que "tudo na vida é aprendizado"!

A minha família e à família do Ricardo, que agora formam uma grande família, por sempre compartilharem a alegria de nossas conquistas! 



\section{AGRADECIMENTOS}

Agradeço, especialmente, ao meu orientador, Prof. Dr. José Fernando Castanha Henriques, pois desde o primeiro contato sempre acreditou no meu trabalho e estimulou meu desenvolvimento profissional. Nestes vários anos de parceria, o senhor sempre permitiu que eu escolhesse minhas pesquisas e ofereceu apoio nos momentos decisivos. Receba meu reconhecimento e minha gratidão!

Minha admiração aos professores colaboradores, Prof. Dr. Rumio Taga Histologia (FOB-USP); Prof. Dr. Carlos Eduardo Francischone - Dentística (FOBUSP); Prof. Dr. José Roberto Pereira Lauris - Estatística (FOB-USP). Em diferentes fases, cada um de vocês teve participação fundamental para a realização desta pesquisa. A vocês agradeço, com carinho, por toda dedicação e atenção.

Minha gratidão aos funcionários, que foram imprescindíveis durante $o$ desenvolvimento deste trabalho, Tânia Cestari - Histologia; Luiz Carlos, Erasmo, Elias e Richard - Biotério.

Um agradecimento especial à bióloga Tânia Cestari, profissional competente, pesquisadora dedicada e pessoa de características singulares. Deixou sua família muitas noites e finais de semana para ficar comigo no laboratório - não tenho palavras para Ihe agradecer, só posso pedir a Deus que retribua em dobro a você e a sua família tudo o que você, incansável, fez por mim e pelo meu trabalho. Serei sempre grata a você! Também agradeço especialmente ao biólogo Luiz Carlos, sempre muito atencioso e disposto a nos ajudar, a qualquer hora, contribuindo para o sucesso da pesquisa e o cuidado com os animais. Muito obrigada!

Aos Professores da Disciplina de Ortodontia, Dr. Arnaldo Pinzan, Dr. Décio Rodrigues Martins, Dr. Guilherme Janson, Dr. Marcos Roberto Freitas e Dr. Renato Rodrigues de Almeida, por terem contribuído tanto para meu aprendizado. Especial agradecimento ao Dr. Guilherme Janson, por ter colaborado para a realização do meu grande sonho de um treinamento no exterior. Por 

seu intermédio, tive a oportunidade de desenvolver pesquisas no Burlington Growth Centre (Universidade de Toronto), sob a orientação do Dr. Bryan Tompson e na Universidade de Michigan, sob a orientação do Dr. James A. McNamara Jr. Obrigada por sua atenção durante este grande desafio para minha vida.

Ao Prof. Dr. Carlos Ferreira dos Santos, parceiro em algumas pesquisas e pessoa com quem sempre posso contar!

Aos funcionários da Disciplina de Ortodontia, Cristina, Daniel, Neide, Sérgio, Tia Maria e Vera, pela amizade ao longo desses anos e por sempre se mostraram prestativos e atenciosos.

Aos colegas do Curso de Doutorado, Alexandre Nakamura, Carlos Henrique, Carlos Cabrera, Darwin Lima, Fernando Torres, Fernando Pedrin, Kelly Chiqueto, Lívia Freitas, Marcus Crepaldi, Marise Cabrera, Rafael Henriques, Renata Castro e Sérgio Estelita, pela convivência agradável e pela troca de experiências científicas e de vida. Vocês tornaram tudo muito divertido. Saudades!

Aos meus queridos orientados de Iniciação Científica, Juliana Mára Titarelli, Juliane Avancini Marsicano, Renata Biella de Salles Oliveira, Mauricio Donalonso Spin e Guilherme Alencar Jacob, por sua responsabilidade e dedicação às pesquisas, e por aceitarem a minha orientação e meus conselhos. Espero ter contribuído para a formação de vocês, mas tenham a certeza de que vocês, com suas dúvidas, permitiram que eu aprendesse muito. Terei sempre boas lembranças de todos!

Agradeço à Faculdade de Odontologia de Bauru - USP, destacando seus dirigentes, Prof. Dr. Luiz Fernando Pegoraro (Diretor), Prof. Dr. José Carlos Pereira (Vice-Diretor), Prof. Dr. José Roberto de Magalhães Bastos (Prefeito do Campus) e Profa. Dra. Maria Aparecida de Andrade Moreira Machado (Presidente da Comissão de Pós-Graduação). Nesta faculdade, obtive toda minha formação e dela sempre irei me orgulhar. 

Aos demais professores e funcionários da Faculdade de Odontologia de Bauru - USP, pois todos, de alguma forma, participaram da minha formação profissional.

Agradeço ao CNPq, pela concessão da bolsa de estudos e de recursos para a realização desta pesquisa.

À empresa Exopro $L A \Theta$, pelo desenvolvimento e doação de todos os implantes desta pesquisa.

\section{À Universidade Norte do Paraná (UNOPAR) e aos seus dirigentes,} que acreditaram no meu trabalho e foram pacientes em aguardar o término das minhas atividades em Bauru.

Aos colegas de trabalho e amigos, Ana Cláudia, Márcio, Renato e Ricardo - muitos foram os desafios superados até aqui e muito outros virão pela frente, mas com respeito às pessoas, dignidade e profissionalismo vamos continuar com nosso trabalho e com certeza, num futuro próximo, todo esforço e dedicação terão valido à pena!

Ao meu querido afilhado Gustavo, com quem, enfim, poderei passar mais tempo e acompanhar seus passos.

A todos meus amigos, que participam dos momentos importantes da minha vida! 

Resumo 



\section{RESUMO}

O objetivo deste trabalho foi avaliar a taxa de sucesso, a quantidade de perda óssea em altura e a interação osso/implante para três diferentes protocolos: 1) implantes osseointegráveis mantidos sem carga durante período de reparo de 120 dias; 2) implantes submetidos a interferências oclusais; e 3) implantes que receberam carga imediata para ancoragem ortodôntica. Foram utilizados doze minipigs BR-1, nos quais foram instalados 70 implantes osseointegráveis de titânio $(3,75 \mathrm{~mm}$ diâmetro $\mathrm{x}$ 8,50mm comprimento), divididos em 5 grupos: Grupo $1(n=12)$, implantes sem carga sepultados na mesial de caninos; Grupo $2(n=6)$, implantes sem carga em áreas de extração; Grupo 3 ( $n=12)$, implantes expostos a interferências oclusais; Grupo 4 $(n=20)$, implantes submetidos à carga ortodôntica imediata; Grupo $5(n=20)$, implantes instalados em áreas de extração e submetidos à carga ortodôntica imediata. Ao término do período experimental, os animais foram eutanasiados e biópsias da região de interesse coletadas. Realizou-se avaliação clínica para estabelecer a porcentagem de sucesso (Teste Exato de Fisher), análise radiográfica para quantificar a perda óssea em altura (programa de análise de imagens KS300Zeiss ${ }^{\circledR}$, ANOVA) e análise histológica para descrever as características da interface osso/implante. A análise dos dados demonstrou: 1) Grupos 1, 2, 4 e 5 - taxa de sucesso, quantidade de perda óssea em altura e interação osso/implante semelhantes; 2) Grupo 3 - taxa de insucesso e quantidade de perda óssea significantemente maiores que os demais grupos, além de apresentar ausência de interação osso/implante. Os resultados clínicos, radiográficos e histológicos revelados nos grupos submetidos à carga ortodôntica imediata em relação aos grupos sem carga demonstraram que a perda óssea na região da crista óssea periimplantar é aceitável e não compromete a estabilidade clínica dos implantes. Desta forma, a utilização de carga imediata para ancoragem em Ortodontia não prejudica a posterior utilização desses implantes para a reabilitação protética, objetivo primário da indicação deste protocolo. Estudos clínicos prospectivos são necessários para comprovar estes dados. 



\section{Abstract}





\section{ABSTRACT \\ Immediately loaded osseointegrated implants for orthodontic anchorage: study in minipigs}

This research aimed at evaluating the success rate, the bone height loss, and the bone/implant interface in three different protocols: 1) osseointegrated implants maintained without load during a repair period of 120 days; 2) osseointegrated implants submitted to occlusal interferences; and 3) immediately loaded osseointegrated implants for orthodontic anchorage. Twelve BR-1 minipigs were used, in which 70 osseointegrated titanium implants were inserted $(3.75 \mathrm{~mm}$ diameter $x 8.50 \mathrm{~mm}$ length), divided into 5 groups: Group $1 \quad(n=12)$, submerged implants without load; Group 2 ( $n=6)$, implants without load in extraction sites; Group $3(n=12)$, implants exposed to occlusal interferences; Group $4(n=20)$, exposed implants submitted to immediate orthodontic load; Group $5(n=20)$, exposed implants inserted in extraction sites and submitted to immediate orthodontic load. At the end of the experimental period, the animals were euthanized and biopsies of the areas of interest were harvested. The clinical analysis (Exact Fisher Test) revealed the success rate of the inserted implants, the radiographic analysis quantified the bone height loss (image analysis program KS300-Zeiss ${ }^{\circledR}$, ANOVA), and the histological analysis showed the bone/implant interface characteristics. The data analysis revealed: 1) Groups 1, 2, 4 and 5 - similar success rate, bone height loss and bone/implant interface characteristics; 2) Group 3 - statistically greater fail rate and bone height loss, and absence of bone/implant interaction characteristics. Clinical, radiographic and histological results presented in the groups submitted to immediate orthodontic load compared with the other without load demonstrated that the bone loss in the bone crest area is acceptable, and does not compromise the clinical stability of the implants. Therefore, the use of immediate load for orthodontic anchorage did not jeopardize the subsequent use of the implants for oral prosthetic rehabilitation, the main objective of this protocol. Further clinical studies are necessary to confirm these data. 



\section{LISTA DE FIGURAS}

FIGURA 1. Gráfico ilustrando o crescimento do número de pesquisas indexadas no PubMed utilizando o minipig como modelo experimental nas diferentes áreas da biomedicina.

FIGURAS 2 A e B. Biotério da FOB-USP: setor das baias, no qual os animais permaneceram durante a pesquisa

FIGURAS 3 A e B. A) Implantes osseointegráveis de plataforma regular; B) Implantes osseointegráveis de plataforma regular com corpo único

FIGURA 4. Contenção do animal, por meio de rede suspensa 84

FIGURAS 5 A-D. A) Veia marginal da orelha após tricotomia na região; B) Introdução do catéter; C) Catéter em posição e estabilizado; D) Animal na fase pré-cirúrgica em venóclise

FIGURA 6. Equipe atuando durante as intervenções 86

FIGURAS 7 A-D. A e B) Anti-sepsia intra e extrabucal com PVPI tópico; C) Animais cobertos com campos operatórios estéreis; D) Incisão intrabucal 88

FIGURAS 7 E-J. E) Descolamento mucoperiostal; F) Extração dos primeiros pré-molares; G) Instalação dos implantes osseointegráveis em área de extração do primeiro pré-molar; H) Instalação dos implantes osseointegráveis na região mesial dos caninos; I) Implantes osseointegráveis de plataforma regular em posição (sepultados); J) Implantes osseointegráveis com corpo único em posição (expostos) 

FIGURAS 7 K-P: (K) Coaptação das bordas e sutura sobre os implantes sepultados; (L) Coaptação das bordas e sutura nos implantes expostos; M) Mensuração da quantidade de força; N) Mola de secção fechada em posição; 0) Pósoperatório imediato: animal estabilizado em um dispositivo para não se machucar; P) Alimentação pastosa na fase póscirúrgica atuando durante as intervenções. 90

FIGURAS 8 A e B. Técnica para avaliação da região posterior na maxila: colocação do posicionador intrabucal para filme oclusal e posicionamento do cilindro localizador para a obtenção da radiografia 92

FIGURAS 9 A e B. Técnica para avaliação dos dentes posteriores na mandíbula: colocação do posicionador intrabucal para filme periapical e posicionamento do cilindro localizador para a obtenção da radiografia 92

FIGURAS 10 A-F. Agitador (EXAKT 510 Dehydration \& Infiltration System, EXAKT; B) Unidade de polimerização (EXAKT 520 Light Polymerization Unit, EXAKT); C) Sistema de precisão para adesão das lâminas (EXAKT 402, Precision Adhesive Press, EXAKT); D) Micrótomo para tecido duro (EXAKT Diamond Band Saw, EXAKT); E) Fitas impregnadas por partículas de diamante (Diamond Cutting Band, 0,2 mm, D64, EXAKT) F) Politriz (EXAKT Grinding Systems). 95

FIGURA 11. Sistema de análise de imagem KS300® utilizado para a avaliação da perda óssea em milímetros ao redor dos implantes 

FIGURA 12. Fotomicrografia em secção transversal do implante sepultado, 120 dias após sua instalação (Grupo 1). Observar a grande quantidade de tecido ósseo periimplantar de arranjo trabeculado e os espaços medulares (MO) em ambos os lados. Neste caso, pontos de contato (seta vermelha) entre o tecido ósseo e a superfície do implante (Imp) ocorrem em toda a extensão do implante, além de áreas de reabsorção associadas à neoformação óssea (seta verde). Notar Saucerização periimplantar (Sp) nos lados esquerdo e direito. Azul de Toluidina. 109

FIGURA 13. Fotomicrografia em secção longitudinal do implante sepultado em área de extração, 120 dias após sua instalação (Grupo 2). Observar a grande quantidade de tecido ósseo periimplantar de arranjo mais compacto e os espaços medulares (MO). Neste caso, zonas de contato (seta vermelha) entre o tecido ósseo e a superfície do implante (Imp) ocorrem em toda a extensão do implante, além de áreas de reabsorção associadas à neoformação óssea (seta verde). Saucerização periimplantar (Sp) pode ser observada na região da crista óssea alveolar no lado esquerdo, enquanto que no lado direito a altura da crista óssea foi mantida ao nível do parafuso de cobertura. Azul de Toluidina.

FIGURA 14. Fotomicrografia em secção longitudinal do implante exposto a interferências oclusais, 120 dias após sua instalação (Grupo 3). Observar a epitelização (seta vermelha) da superfície do implante (Imp) e a presença de tecido conjuntivo (TC) envolvendo grande parte da região periimplantar e pequenas porções de tecido ósseo remanescentes da reabsorção (asterisco). Veja na imagem central panorâmica que neste caso o implante (Imp) encontra-se ancorado ao tecido ósseo (TO) apenas na 

região da câmara de ossificação apical. Azul de Toluidina

FIGURA 15. Fotomicrografia em secção longitudinal do implante submetido à carga ortodôntica imediata, 120 dias após sua instalação (Grupo 4). Observar a grande quantidade de tecido ósseo periimplantar de arranjo lamelar e compacto na região de tensão e pressão. Neste caso, no terço cervical o tecido ósseo (TO) mostra-se em íntimo contato (seta vermelha) com a superfície das roscas do implante, e as roscas médias e apicais, em algumas áreas, estão separadas por tecido conjuntivo (TC). Saucerização periimplantar pode ser observada na região da crista óssea alveolar em ambos os lados, sendo que a maior perda óssea ocorreu no lado de pressão. Azul de Toluidina

FIGURA 16. Fotomicrografia em secção longitudinal do implante inserido em área de extração e submetido à carga ortodôntica imediata, 120 dias após sua instalação (Grupo 5). Observar a grande quantidade de tecido ósseo periimplantar de arranjo lamelar e altamente compacto na região de pressão e tensão. Neste caso, os contatos (seta vermelha) entre o tecido ósseo e a superfície do implante (Imp) ocorrem em grande parte da extensão do implante, enquanto que a interposição de tecido conjuntivo (TC) praticamente inexiste. Saucerização periimplantar (Sp) pode ser observada na região da crista óssea alveolar em ambos os lados, sendo que a maior perda óssea ocorreu no lado de pressão. Azul de Toluidina. 



\section{LISTA TABELAS}

Tabela 1. Grupos 1-5: Implantes estáveis 120 dias após a instalação, implantes perdidos, total de implantes instalados 101

Tabela 2. Teste Exato de Fisher: comparação entre os Grupos 1-5, considerando-se os implantes estáveis após 120 dias da instalação e os implantes perdidos. 102

Tabela 3. Implantes instalados na maxila Grupos 1-5: Implantes estáveis 120 dias após a instalação, implantes perdidos, total de implantes instalados na maxila 102

Tabela 4. Implantes instalados na mandíbula Grupos 1-5: Implantes estáveis 120 dias após a instalação, implantes perdidos, total de implantes instalados na mandíbula 103

Tabela 5. Teste Exato de Fisher: comparação entre os implantes instalados na maxila e na mandíbula, para cada um dos grupos, considerando-se os implantes estáveis após 120 dias da instalação e os implantes perdidos 103

Tabela 6. Perda óssea em altura $(\mathrm{mm})$ nos lados de tensão (esquerdo) e pressão (direito): média, desvio-padrão (DP) das duas medições, teste "t" pareado $(P)$ e erro de Dahlberg (Erro) 104

Tabela 7. Perda óssea em altura $(\mathrm{mm})$ no lado esquerdo (tensão) para os Grupos 1-5: Média e Desvio-Padrão (DP) 104

Tabela 8. Comparação da perda óssea em altura $(\mathrm{mm})$, para os Grupos 1-5, no lado esquerdo (tensão): médias e valores de $P$ 105

Tabela 9. Perda óssea em altura $(\mathrm{mm})$ no lado direito (pressão) para os Grupos 1-5: Média e Desvio-Padrão (DP) 105 

Tabela 10. Comparação da perda óssea em altura $(\mathrm{mm})$, para os Grupos 1-5, no lado direito (pressão): médias e valores de $P$ 106

Tabela 11. Comparação da perda óssea em altura $(\mathrm{mm})$, entre os lados esquerdo e direito, para os Grupos 1-5: média, desviopadrão (DP) e valores de $\mathrm{P}$ ): médias e valores de $\mathrm{P}$ 106 



\section{SUMÁRIO}

1. INTRODUÇÃO

2. REVISÃO DE LITERATURA 53

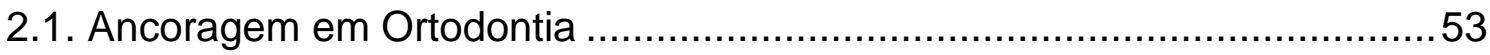

2.2. Características dos implantes osseointegráveis.........................................55

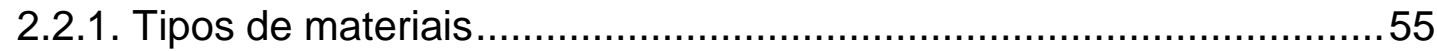

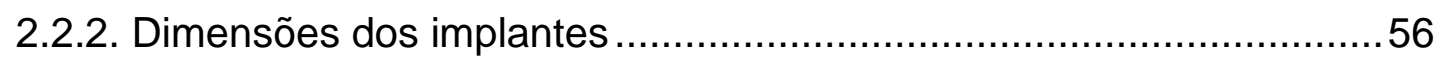

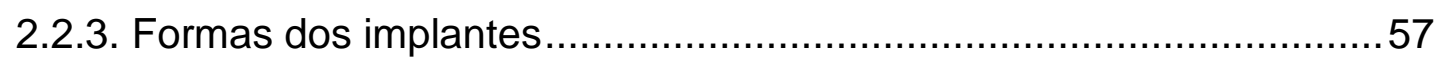

2.2.4. Áreas de escolha para a colocação dos implantes ...........................57

2.2.5. Biomecânica e níveis de força ..................................................... 59

2.3. Implantes osseointegráveis para ancoragem ortodôntica ..........................60

2.4. Carga imediata sobre implantes osseointegráveis ....................................64

2.5. O minipig como modelo experimental .....................................................6

3. PROPOSIÇÃO

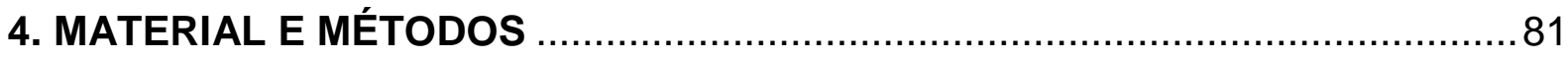

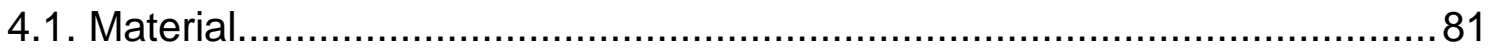

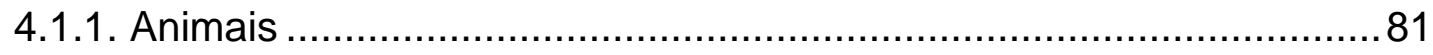

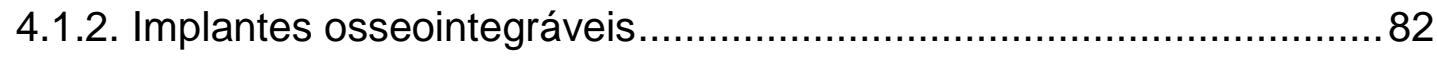

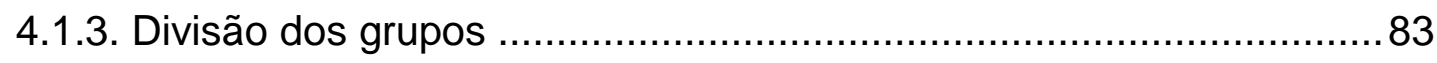

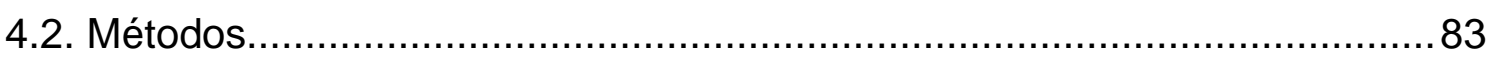

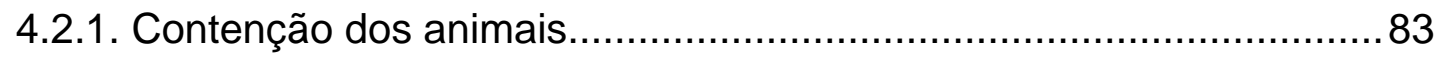

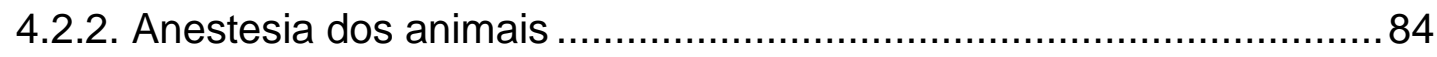

4.2.3. Preparo dos animais e procedimentos cirúrgicos ............................ 86

4.2.4. Obtenção das Radiografias............................................................ 91

4.2.5. Obtenção das biópsias e preparo histotécnico ..................................93

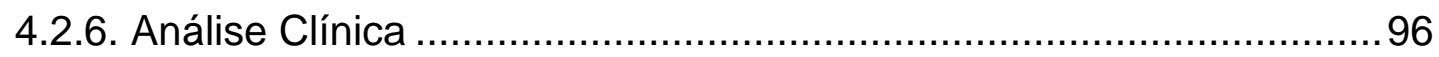

4.2.7. Avaliação radiográfica quantitativa da perda óssea ..........................96

4.2.7.1. Análise comparativa entre os grupos ...................................98

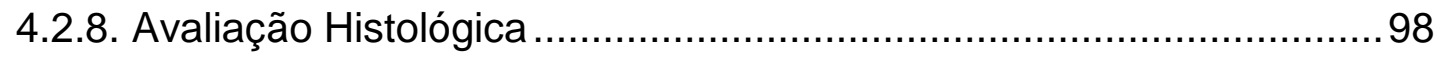



5. RESULTADOS

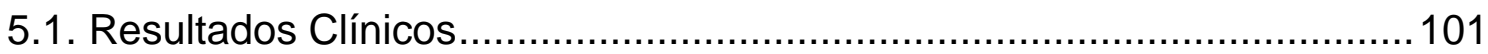

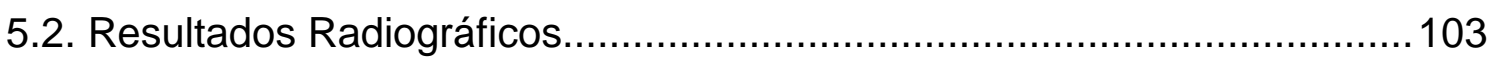

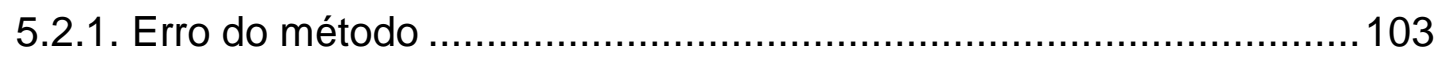

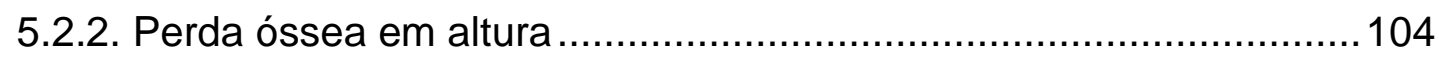

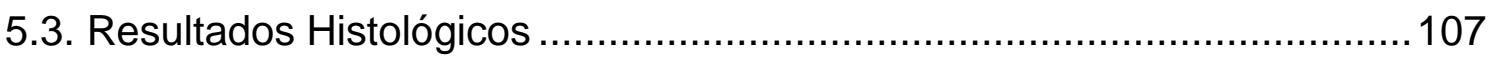

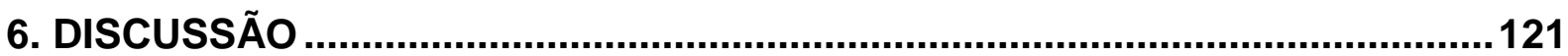

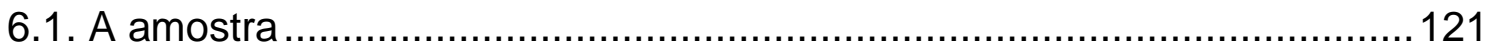

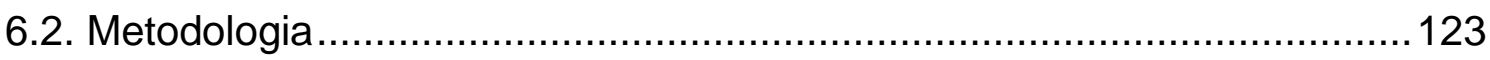

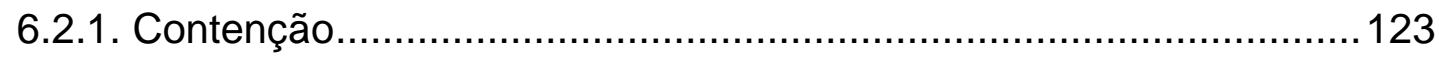

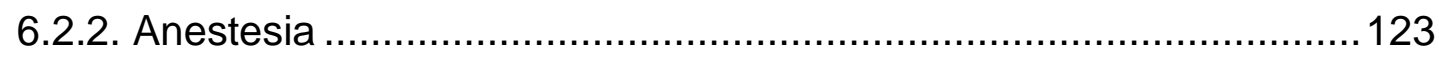

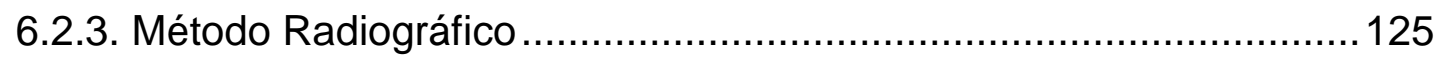

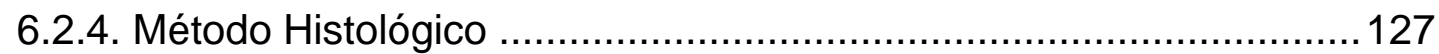

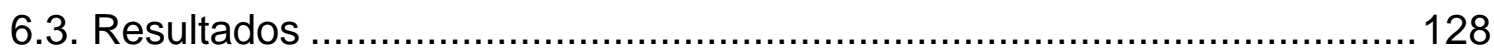

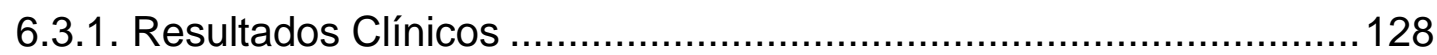

6.3.2. Resultados da avaliação radiográfica quantitativa da perda

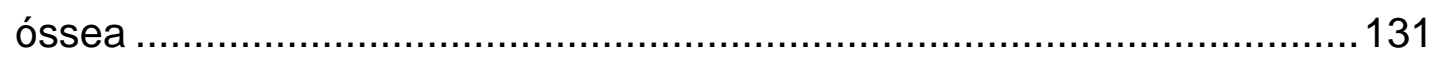

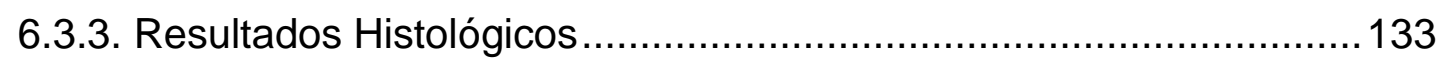

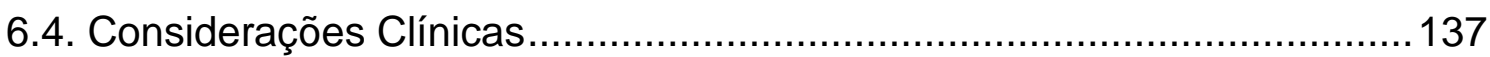

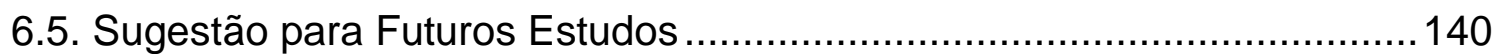

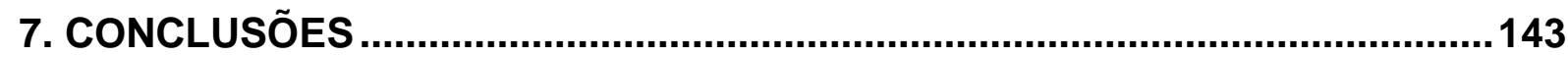

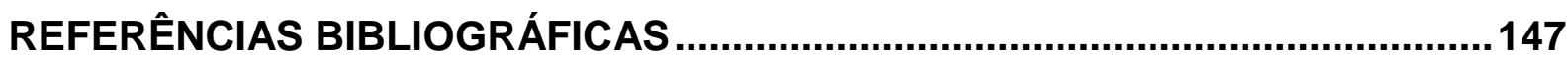

APÊNDICE 

1. Introdução 



\section{INTRODUÇÃO}

Com as perspectivas inerentes aos conceitos e técnicas da osseointegração, introduzidos por BRANEMARK et al. (1969a), ocorreu um grande avanço na Odontologia no que se refere ao planejamento e tratamento dos pacientes. A reabilitação do edentulismo, nos casos totais, parciais e unitários, por meio da utilização de implantes metálicos osseointegráveis, consolidou-se como uma técnica previsível e executável para o clínico (ADELL et al., 1981).

A Ortodontia, cujo objetivo final é a estética aliada à reabilitação do sistema estomatognático, com ênfase na estabilidade funcional, tem se beneficiado sobremaneira da interação com a Implantodontia (FERREIRA, 2002; FRANCISCHONE et al., 2003; LIEBENBERG, 1996).

Durante o planejamento e a realização do tratamento ortodôntico, o profissional pode encontrar dificuldades para o estabelecimento de uma ancoragem adequada. A característica ideal da ancoragem eficiente depende das forças aplicadas, tipo de aparelho utilizado, característica do movimento dentário desejado, posição, tamanho, número de dentes e características do osso alveolar de suporte dos elementos dentários envolvidos (CELENZA; HOCHMAN, 2000; CREEKMORE; EKLUND, 1983; GRAY et al., 1983).

Especial importância deve ser dada aos pacientes adultos, nos quais a ancoragem ortodôntica pode estar comprometida pela ausência de um ou mais elementos dentários, especialmente nas regiões posteriores, dificultando ou até tornando impossível a movimentação e o posicionamento ideal dos dentes remanescentes, havendo a necessidade de um modelo alternativo de ancoragem (GALLAS et al., 2005; TRISI; REBAUDI, 2002; TURLEY et al., 1988).

Esta necessidade clínica estimulou o desenvolvimento de inúmeros trabalhos experimentais (GAINSFORTH; HIGLEY, 1945; GRAY et al., 1983; ROBERTS et al., 1984; SHERMAN, 1978; SMALLEY et al., 1988; TURLEY et al., 1988) para pesquisar o uso de implantes como ancoragem para a ortodontia e ortopedia. A obtenção de resultados satisfatórios, a partir da realização destas pesquisas preliminares, possibilitou a utilização de implantes osseointegráveis para ancoragem ortodôntica em humanos (DE PAUW et al., 1999; HIGUCHI; SLACK, 1991; LIEBENBERG, 1996; LINKOW, 1969,1970; ÖDMAN et al., 1988; ÖDMAN et 
al., 1994; ROBERTS et al., 1990; ROBERTS et al., 1994; SHAPIRO; KOKICH, 1988; SHUFFORD; KRAUT, 1989).

Com o estabelecimento do uso de implantes osseointegráveis com finalidade de ancoragem ortodôntica, as pesquisas foram direcionadas a outros aspectos relacionados ao binômio Ortodontia-Implantodontia, como os níveis de força gerados pela movimentação ortodôntica e aplicados sobre os implantes (CELENZA; HOCHMAN, 2000; GALLAS et al., 2005; HIGUCHI; SLACK, 1991; ÖDMAN et al., 1994; ROBERTS et al., 1994; WEHRBEIN et al., 1998) e o tempo de remodelação óssea necessário após a colocação do implante para o início da ativação ortodôntica (KOKICH, 2000; TRISI; REBAUDI, 2002). Estes trabalhos indicaram que as forças geradas no implante durante a ativação ortodôntica podem ser recebidas como menos deletérias que as forças oclusais.

A partir destas conclusões obtidas, passou-se a admitir que os implantes instalados, com objetivo primário de servirem como ancoragem ortodôntica, poderiam ser submetidos a cargas mais precoces em relação àqueles inseridos para reabilitação oclusal, diminuindo o tempo de espera necessário. ROBERTS et al. (1989) relataram que o tempo médio necessário para osseointegração antes da inserção de carga era de 12 semanas em cães, e períodos de reparação de 8 a 20 semanas foram relatados em estudos experimentais (SAITO et al., 2000; TURLEY et al., 1988) e 3 a 6 meses em estudos clínicos (ÖDMAN et al., 1994; ROBERTS et al., 1990; SHELLHART et al., 1996; WEHRBEIN et al., 1996; WEHRBEIN et al., 1998).

Alguns autores (ALDIKAÇTI et al., 2004; COCHRAN et al., 1998; OYONARTE et al., 2005b,2005a; ROBERTS et al., 1989; ROBERTS et al., 1984) testaram a aplicação de carga precoce sobre implantes para ancoragem ortodôntica, obtendo resultados favoráveis. Baseados nessas pesquisas e em outras que estudaram a carga imediata sobre implantes utilizados para reabilitação (BIJLANI; LOZADA, 1996; BUSER et al., 1988; CHIAPASCO et al., 1997; COLOMINA, 2001; COOPER, et al. 2001; ESPOSITO et al., 2007; LORENZONI et al., 2003; NKENKE et al., 2005a; NKENKE et al., 2005b; RANDOW et al., 1999; SALAMA et al., 1995), julgamos válida a possibilidade da utilização de carga imediata sobre implantes que serão inicialmente utilizados para ancoragem ortodôntica, e posteriormente aproveitados para a reabilitação protética de pacientes.

Assim, o presente trabalho objetiva avaliar o uso de carga ortodôntica imediata sobre implantes convencionais, com vistas a diminuir o tempo de 
tratamento de pacientes que necessitem desta modalidade de ancoragem, além de investigar a viabilidade destes implantes para posterior reabilitação protética. 

2. Revisão da Literatura 



\section{REVISÃO DA LITERATURA}

Com a finalidade de facilitar a compreensão e a interpretação dos resultados desta pesquisa e de suas implicações clínicas, dividiu-se este capítulo em tópicos, de acordo com a seqüência descrita abaixo:

\subsection{Ancoragem em Ortodontia}

\subsection{Características dos implantes osseointegráveis}

\subsubsection{Tipos de materiais}

\subsubsection{Dimensões dos implantes}

\subsubsection{Formas dos implantes}

\subsection{4. Áreas de escolha para a colocação dos implantes}

\subsubsection{Biomecânica e níveis de força}

\subsection{Implantes osseointegráveis para ancoragem ortodôntica}

\subsection{Carga imediata em implantes osseointegráveis}

\subsection{0 minipig como modelo experimental}

\subsection{Ancoragem em Ortodontia}

O termo ancoragem em ortodontia consiste na resistência à movimentação indesejada de um elemento dentário (PROFFIT; FIELDS JR, 2000). A importância da ancoragem pode ser descrita pela famosa citação do filósofo grego Arquimedes: "Dê-me um ponto de apoio e eu moverei a Terra". A ancoragem ortodôntica pode também ser explicada pela Terceira Lei de Newton, a qual determina que a cada ação corresponda uma reação, na mesma intensidade e em sentido oposto. A unidade anatômica que antagoniza a força ativa é denominada de ancoragem (EVERDI et al., 2005; GAINSFORTH; HIGLEY, 1945; HIGUCHI, 2005; HIGUCHI; SLACK, 1991; LIEBENBERG, 1996; PROFFIT; FIELDS JR, 2000; ROBERTS-HARRY; SANDY, 2004; TURLEY et al., 1988; VAN ROEKEL, 1989).

O ortodontista sempre planeja um tratamento para produzir alguns movimentos dentários desejáveis, e para cada movimento desejável, existe outro, às 
vezes indesejável (EVERDI et al., 2005). Assim, a ancoragem ortodôntica é usualmente obtida utilizando-se um dente ou um grupo de dentes que suportem 0 efeito da movimentação de outros dentes mal posicionados, sendo o desempenho desta ancoragem determinado pela posição, tamanho, número de dentes e características do osso alveolar de suporte dos elementos dentários envolvidos (CELENZA; HOCHMAN, 2000; CREEKMORE; EKLUND, 1983; GRAY et al., 1983). Se durante a aplicação de forças para a movimentação dentária não existe a disponibilidade adequada de ancoragem, os dentes a serem movimentados (unidade de ação) podem não se movimentar ou pode haver mudanças na posição dos dentes que deveriam resistir à movimentação (unidade de reação, unidade inativa ou de ancoragem) (HIGUCHI, 2005).

Assim, a obtenção de uma ancoragem ideal ainda constitui um desafio para o tratamento ortodôntico, isso porque freqüentemente as ancoragens recaem sobre estruturas potencialmente móveis (dentes), ou então porque requerem total colaboração e habilidade dos pacientes (uso de aparelho extrabucal ou elásticos). Existem, ainda, os aparelhos que promovem reforço de ancoragem, assim como a Placa Lábio-Ativa e os aparelhos de Nance, que são incômodos, desconfortáveis, inconvenientes e difíceis de serem higienizados (CELENZA; HOCHMAN, 2000; CREEKMORE; EKLUND, 1983; GRAY et al., 1983). As ancoragens baseadas em elementos dentários podem estar comprometidas pela presença de doença periodontal ou pela ausência de vários elementos dentários. Nesses casos, haveria a necessidade de um modelo alternativo de ancoragem.

Em algumas dessas circunstâncias, seria desejável possuir uma unidade de ancoragem que pudesse ser inserida na boca e se mantivesse estável durante 0 recebimento de forças, para que assim a movimentação de outros dentes pudesse ser realizada, sem que houvesse perda desta ancoragem (SAITO et al., 2000).

Nesse sentido, as pesquisas disponibilizaram aos ortodontistas algumas opções de dispositivos capazes de promover uma ancoragem absoluta e facilitar sobremaneira o planejamento e a execução do tratamento ortodôntico. Dentre esses, é importante citar: os implantes osseointegráveis (HIGUCHI, 2005; ÖDMAN et al., 1988; ROBERTS et al., 1990; ROBERTS et al., 1984; TURLEY et al., 1988; VAN ROEKEL, 1989), os implantes palatinos (WEHRBEIN et al., 1996), as 
miniplacas (UMEMORI, 1999), os onplants (BLOCK; HOFFMAN, 1995), e os miniimplantes (BÜCHTER et al., 2005; OHMAE et al., 2001; PARK et al., 2003).

\subsection{Características dos implantes osseointegráveis}

A ancoragem absoluta é uma alternativa às metodologias tradicionais de ancoragem; porém, é uma necessidade quando há perda de elementos dentários ou os dentes presentes encontram-se comprometidos, quando os aparelhos extrabucais são impraticáveis, ou quando há a dificuldade de se obter colaboração do paciente durante o tratamento ortodôntico. O aumento da demanda por métodos de tratamento que requeiram mínima colaboração, particularmente pelos adultos, e a importância dada à estética levaram à expansão da tecnologia nesta área (ALDIKAÇTI et al., 2004; FAVERO et al., 2002; WEHRBEIN et al., 1996).

A literatura científica contém uma abundância de informações sobre os implantes, especialmente após 0 advento dos implantes osseointegráveis (BRANEMARK et al., 1969a) que aumentou ainda mais o interesse por esse assunto. Este tópico foi subdividido para brevemente destacar assuntos relativos aos implantes: tipo de materiais, dimensão, forma, biomecânica e níveis de força.

\subsubsection{Tipos de materiais}

Nos diversos sistemas de implantes são utilizados diferentes materiais. Independente do material utilizado, ele deve ser atóxico e biocompatível, apresentar propriedades mecânicas favoráveis e ser capaz de resistir à pressão e à tensão. Além disso, sua eficiência deve ser provada em estudos experimentais e clínicos. Os materiais mais comumente utilizados podem ser divididos em 3 categorias: biotolerantes (aço inoxidável, ligas de cromo-cobalto), bioinertes (titânio, carbono), e bioativas (vetroceramic apatite hydroxide, cerâmicas de óxido de alumínio, óxido de titânio e óxido de zinco) (FAVERO et al., 2002; HUANG et al., 2005). 
Comercialmente, o titânio puro é o material mais freqüentemente empregado em Implantodontia. Ele consiste de $99,5 \%$ de titânio e $0,5 \%$ de outros elementos, assim como carbono, oxigênio, nitrogênio e hidrogênio. É considerado um excelente material, pois não existem relatos na literatura que correlacionem 0 titânio com o desenvolvimento de neoplasias ou reações alérgicas. Além disso, possui características mecânicas como leveza e alta resistência à tração e à fratura, o que o permite suportar as forças mastigatórias e ortodônticas (HUANG et al., 2005; KRAUT et al., 1988; LIEBENBERG, 1996; LINKOW, 1969,1970; SORENSON, 1995).

As pesquisas continuam em busca de novos biomateriais, e o estudo de superfícies bioativas tem o objetivo de melhorar a integração entre osso e implante. Os trabalhos que investigam materiais reabsorvíveis são interessantes, pois estes materiais poderiam eliminar, em alguns casos, as cirurgias de re-entrada para a remoção da fixação e preservariam desta forma o tecido ósseo. Em estudos preliminares, implantes confeccionados de materiais reabsorvíveis demonstraram resultados positivos (GLATZMAIER et al., 1995,1996). GLATZMAIER et al. (1995), em 1995, demonstraram in vitro que implantes reabsorvíveis poderiam suportar forças horizontais de $50 \mathrm{~N}$ e forças verticais de $155 \mathrm{~N}$ sem perderem a ancoragem.

\subsubsection{Dimensões dos implantes}

Os implantes devem oferecer estabilidade primária e suportar as forças aplicadas sobre eles. A carga máxima suportada é proporcional à quantidade de osseointegração, tornando-a dependente do contato osso-implante. Em função dos implantes serem geralmente cilíndricos, os parâmetros que contribuem para o contato com o tecido ósseo são: comprimento, diâmetro e forma. A combinação dessas variáveis deve produzir um contato com a superfície óssea que seja suficiente para as necessidades protéticas ou ortodônticas, causando pequeno trauma cirúrgico e possibilitando a distribuição de forças ao longo das linhas biológicas, na tentativa de evitar ou diminuir a reabsorção óssea progressiva (FAVERO et al., 2002; HUANG et al., 2005). 
A dimensão dos implantes deve ser compatível com a disponibilidade óssea. A maioria dos autores utiliza implantes com dimensões tradicionais de $3-4 \mathrm{~mm}$ de diâmetro e 6-10mm de comprimento (ROBERTS et al., 1989; ROBERTS et al., 1990; ROBERTS et al., 1994; TURLEY et al., 1988; WEHRBEIN; DIEDRICH, 1993; WEHRBEIN et al., 1997; WEHRBEIN et al., 1996). Estudos que utilizam implantes com dimensões especiais (BLOCK; HOFFMAN, 1995; KANOMI, 1997; VAN ROEKEL, 1989) demonstraram que a relação comprimento-diâmetro é inversamente proporcional, isto é, se o comprimento é diminuído, o diâmetro deve ser aumentado, e vice-versa. As diferentes dimensões existentes no mercado permitem que os implantes sejam escolhidos conforme anatomia e disponibilidade óssea (KANOMI, 1997).

\subsubsection{Formas dos implantes}

A forma do implante deve fornecer ancoragem mecânica, por meio da superfície de contato com o osso, possibilitando a distribuição de carga funcional sem danos à fisiologia do tecido. Além disso, o desenho do parafuso deve minimizar - trauma cirúrgico durante a instalação e permitir uma estabilidade primária adequada. As formas de parafusos mais utilizadas são a cilíndrica e a cônica, com superfície lisa ou tratada. A superfície dos implantes é tratada, em alguns casos, com o objetivo de criar irregularidades e assim aumentar a superfície disponível para a osseointegração (FAVERO et al., 2002; HUANG et al., 2005).

\subsection{4. Áreas de escolha para a colocação dos implantes}

A seleção das áreas para colocação de implantes depende de vários fatores: a função do implante, idade esquelética do paciente, qualidade e quantidade de tecido ósseo disponível (BLOCK; HOFFMAN, 1995; DE PAUW et al., 1999; LINDER-ARONSON et al., 1990; SMALLEY, 1995; TURLEY et al., 1988). 
Nos casos em que o implante terá função dupla (ancoragem ortodôntica e reabilitação protética), a área de escolha deve satisfazer duas condições: o local deve ser bem planejado em modelos de estudo, para não prejudicar o tratamento ortodôntico; e ao final do tratamento o implante deve manter a posição sugerida para a reabilitação protética (SMALLEY, 1995).

A idade esquelética deve ser determinada em pacientes jovens, por meio de exames radiográficos seriados, com a finalidade de realizar a colocação dos parafusos após o crescimento. Isso porque, uma vez que os implantes são como dentes anquilosados, eles não acompanham o crescimento e o desenvolvimento dos maxilares, e não irrompem juntamente com os dentes adjacentes, tornando-se deslocados tanto no sentido sagital como transversal, o que causa um dano estético e funcional acentuado (ÖDMAN et al., 1991; SENNERBY et al., 1993; THILANDER et al., 1992).

Para a verificação da quantidade e qualidade de tecido ósseo disponível, - profissional deve utilizar exames radiográficos pré-cirúrgicos (radiografia panorâmica, telerradiografia, radiografias intrabucais, tomografia computadorizada), além de exame intrabucal por palpação e medição da espessura da mucosa (FAVERO et al., 2002; SMALLEY, 1995).

Os locais de escolha geralmente recaem sobre o osso alveolar em áreas de agenesia ou extração dentária (SMALLEY, 1995; TURLEY et al., 1988; WEHRBEIN; DIEDRICH, 1993; WEHRBEIN et al., 1997), área retromolar (HIGUCHI; SLACK, 1991; ROBERTS et al., 1996; ROBERTS et al., 1990; ROBERTS et al., 1994; WEHRBEIN et al., 1998), e osso zigomático (DE PAUW et al., 1999; SMALLEY et al., 1988; TURLEY et al., 1988).

Em adultos com dentadura permanente completa, a principal indicação dos implantes é a ancoragem ortodôntica, para evitar o uso de aparelhos antiestéticos e que requeiram a colaboração do paciente. Para estes casos existe atualmente uma série de opções de tratamento utilizando dispositivos temporários de tamanho reduzido, como os implantes palatinos (WEHRBEIN et al., 1996), as miniplacas (UMEMORI, 1999), os onplants (BLOCK; HOFFMAN, 1995), e os miniimplantes (CHUNG et al., 2005; LEE et al., 2004; LEE et al., 2001; OHMAE et al., 2001; OHNISHI et al., 2005; PARK et al., 2001; PARK; KWON, 2004; PARK et al., 2004a; PARK et al., 2004b; PARK et al., 2005; PARK et al., 2003). 
Para os casos de adultos com edentulismo parcial, a utilização de implantes que servirão para ancoragem ortodôntica e reabilitação protética apresenta um custo-benefício positivo. A realização de um set-up diagnóstico é fundamental antes da instalação dos parafusos, para estabelecer uma adequada reabilitação protética (HIGUCHI, 2005; KRAUT et al., 1988; PROSTERMAN et al., 1995; SHELLHART et al., 1996; SMALLEY, 1995; VAN ROEKEL, 1989).

\subsubsection{Biomecânica e níveis de força}

Inicialmente, os implantes devem apresentar estabilidade primária e, após o tempo de reparação, devem suportar forças de pressão e tensão aplicadas sobre eles (FAVERO et al., 2002; HUANG et al., 2005).

Há uma grande diferença no que diz respeito às forças ortodônticas e forças protéticas (GALLAS et al., 2005). Quando o implante é utilizado para reabilitação protética, ele recebe forças descontínuas e verticais, que podem ser estimadas em quilogramas. Ao contrário, a força ortodôntica aplicada sobre os implantes é normalmente contínua, horizontal e de baixa intensidade $(\mathrm{KOKICH}$, 2000). O desenho do parafuso e do intermediário deve ser adequado a estas diferenças importantes, e considerar os princípios biomecânicos requeridos pelo tipo de movimento dentário desejado e a anatomia do paciente. A carga máxima aplicável sobre os implantes é proporcional ao diâmetro e comprimento do implante, à qualidade do tecido ósseo e ao grau de osseointegração (BLOCK; HOFFMAN, 1995; DE PAUW et al., 1999; GRAY et al., 1983; ROBERTS et al., 1996; ROBERTS et al., 1989; ROBERTS et al., 1990; ROBERTS et al., 1994; SHERMAN, 1978; SMALLEY et al., 1988; TURLEY, 1980; TURLEY et al., 1988; WEHRBEIN et al., 1997; WEHRBEIN et al., 1998). 


\subsection{Implantes osseointegráveis para ancoragem ortodôntica}

O desenvolvimento de novas técnicas nas mais diversas áreas da Odontologia tem contribuído sobremaneira para o avanço de recursos entre as especialidades. Nesse sentido, a multidisciplinaridade Ortodontia-Implantodontia, amparada por métodos científicos e pesquisas clínicas, tem-se mostrado muito eficaz no tratamento quando da ausência de alguns elementos dentários e tem conseguido atingir os objetivos terapêuticos no que se refere à estética e funcionalidade (FERREIRA, 2002; FRANCISCHONE et al., 2003; LIEBENBERG, 1996).

GAINSFORTH e HIGLEY (1945) foram os primeiros autores a considerarem possível a utilização de implantes como ancoragem ortodôntica na movimentação de dentes naturais, utilizando fios ortodônticos e parafusos metálicos de vitallium cirúrgico, fixados ao osso basal da região do ramo da mandíbula de um cão, obtendo resultados parciais na movimentação dos dentes, tendo sido perdidos os parafusos após poucas semanas de movimentação.

Após este estudo, LINKOW (1969) relatou a utilização de implantes como ancoragem durante a movimentação ortodôntica. Outros estudos reportados na literatura não receberam destaque em função da falta de adesão de tecido ósseo à superfície dos implantes (LIEBENBERG, 1996). Apenas com o trabalho de BRANEMARK et al. (1969a) pôde-se demonstrar que os implantes de titânio permaneciam estáveis por períodos maiores que cinco anos, mesmo que submetidos a cargas excessivas.

Assim, muitas pesquisas (CREEKMORE; EKLUND, 1983; GRAY et al., 1983; HIGUCHI; SLACK, 1991; LINKOW, 1970; ÖDMAN et al., 1988; SHERMAN, 1978; SHUFFORD; KRAUT, 1989; SMITH, 1979; TURLEY, 1980; VAN ROEKEL, 1989) passaram a destacar os implantes osseointegráveis, considerando as diferentes geometrias e materiais de composição, como dispositivos que facilitam a ancoragem durante a movimentação ortodôntica.

O uso dos implantes osseointegráveis passou a ser discutido e considerado a partir dos resultados positivos obtidos por meio de estudos experimentais em animais de laboratório (LINDER-ARONSON et al., 1990; 
ROBERTS et al., 1984; SMALLEY et al., 1988; TURLEY et al., 1988), os quais demonstraram que os implantes, após receberem carga, permaneciam estáveis (HIGUCHI; SLACK, 1991; ÖDMAN et al., 1991; SENNERBY et al., 1993; THILANDER et al., 1992). Além da estabilidade, havia a ausência de células inflamatórias ou células osteoclásticas, o que confirmava a habilidade do implante em resistir ao movimento recíproco durante o tratamento ortodôntico (BLOCK; HOFFMAN, 1995). Os implantes de titânio inseridos em mandíbulas de suínos em crescimento comportavam-se como dentes anquilosados (ÖDMAN et al., 1991; SENNERBY et al., 1993; THILANDER et al., 1992).

Estes resultados foram confirmados por numerosos estudos clínicos (COCHRAN et al., 1998; HIGUCHI; SLACK, 1991; LINKOW, 1969; ÖDMAN et al., 1994; PROSTERMAN et al., 1995; ROBERTS et al., 1990; ROBERTS et al., 1994; SHELLHART et al., 1996; THILANDER et al., 1994; VAN ROEKEL, 1989; WEHRBEIN; MERZ, 1998; WEHRBEIN et al., 1999; WEHRBEIN et al., 1996; WEHRBEIN et al., 1998), que demonstraram a eficácia da ancoragem fornecida pelos implantes osseointegráveis.

Uma vez que os implantes apresentaram resultados favoráveis, passouse a investigar os níveis de força gerados pelos aparelhos ortodônticos e aplicados sobre os implantes (GOTFREDSEN et al., 2001; HIGUCHI; SLACK, 1991; ÖDMAN, et al. 1994; ROBERTS et al., 1994), especialmente as forças axiais e não axiais (CELENZA; HOCHMAN, 2000). WEHRBEIN et al. (1998) analisaram histomorfometricamente 0 uso de seis implantes de titânio inseridos temporariamente com o objetivo de fornecer ancoragem para a retração dos dentes anteriores superiores e inferiores e na distalização de molares inferiores em humanos. Após terem sido submetidos à carga ortodôntica oblíqua prolongada, os resultados demonstraram que os implantes permaneciam clinicamente estáveis, apesar da aplicação de forças contínuas de magnitude de 2-6N. Diante da análise clínica e histomorfométrica dos implantes submetidos à ancoragem ortodôntica, os autores concluíram a viabilidade e segurança desse processo.

ROBERTS et al. (1984) relataram que a aposição óssea ao redor de implantes osseointegráveis depende de fatores como a magnitude de força, a estrutura óssea e a deformação do tecido ósseo submetido a forças ortodônticas. Já 
MELSEN e COSTA (2000) afirmaram que forças entre 1 e 3N não afetam a remodelação óssea.

GOTFREDSEN et al. (2001), num trabalho em cães, avaliaram os efeitos da aplicação de uma força estática horizontal no tecido ósseo periimplantar. Os autores afirmaram que a carga sobre os implantes aumentou a densidade óssea em comparação ao grupo controle. O aumento da densidade óssea ao redor de implantes submetidos à carga também foi descrito por MELSEN e LANG (2001).

Num estudo clínico TRISI \& REBAUDI (2002) avaliaram 41 pacientes que necessitavam de tratamento ortodôntico em vários tipos de más oclusões. Em 29 pacientes os implantes foram colocados e utilizados posteriormente na reabilitação protética, em 10 pacientes os implantes foram inseridos na região de molar e retromolar, e dois pacientes receberam um implante na região palatina, sendo que um implante da região retromolar recebeu força ortodôntica imediatamente após a sua inserção. De acordo com os resultados dos autores, todos os implantes permaneceram estáveis clinicamente, sem sinais de inflamação. Assim, ficou demonstrada que a eficácia da ancoragem intrabucal independe do tipo de abordagem no tratamento ortodôntico, permite a aplicação de diferentes forças em vários grupos de dentes em diversos locais da boca, e possibilita os movimentos com ancoragem absoluta e em um tempo menor de tratamento do que em condições normais da ortodontia.

Outro aspecto discutido na literatura é o tempo de remodelação óssea necessário após a colocação do implante para o início da ativação ortodôntica. ROBERTS et al. (1989) afirmaram que o tempo médio necessário para osseointegração antes da aplicação de carga sobre os implantes é de 12 semanas em cães. Períodos de reparação de 8 a 20 semanas têm sido relatados em estudos experimentais (SAITO et al. 2000; TURLEY et al., 1988) e 3 a 6 meses em estudos clínicos (ADELL et al., 1981; ÖDMAN et al., 1994; ROBERTS et al., 1990; SHELLHART 1996; WEHRBEIN et al., 1996; WEHRBEIN et al., 1998).

$\mathrm{KOKICH} \mathrm{(2000)} \mathrm{afirmou} \mathrm{que} \mathrm{o} \mathrm{ortodontista} \mathrm{deve} \mathrm{esperar} \mathrm{de} \mathrm{quatro} \mathrm{a} \mathrm{seis}$ meses antes de iniciar a ativação ortodôntica para evitar o emprego de forças excessivas, uma das causas da desintegração óssea ao redor dos implantes. Porém, o autor afirma que as reações produzidas sobre os implantes que servem como ancoragem ortodôntica são mais favoráveis em relação àqueles que recebem 
forças oclusais. Ele acredita que haveria duas fundamentais diferenças entre forças oclusais e forças ortodônticas: as forças ortodônticas são geralmente contínuas, não intermitentes e sempre em uma mesma direção; ao passo que as forças oclusais são sempre intermitentes e aplicadas em direções diferentes. Se a força em um implante é intermitente e em diferentes direções, a mensagem biomecânica transmitida para o implante não é consistente, por isso não existe uma resposta uniforme do osso às forças oclusais. A força gerada no tratamento ortodôntico é regular e na mesma direção, sendo o estímulo biomecânico transmitido ao implante e a resposta da interface osso/implante, uniformes. Desta maneira o autor conclui que as forças geradas no implante durante a ativação ortodôntica podem ser recebidas como menos deletérias que as forças oclusais.

Uma das principais conclusões obtida por meio destes estudos é de ROBERTS (1994): "dentro de limites fisiológicos, os implantes osseointegráveis promovem excelente ancoragem ortodôntica e ortopédica". Além disso, segundo SMALLEY (1995), é importante a abordagem multidisciplinar para se conseguir resultados ótimos quando da utilização de implantes osseointegráveis como ancoragem fixa para ortodontia. A localização e orientação dos implantes, assim como a previsão de posição dentária pós-ortodontia, são fatores determinantes para utilização dos implantes na movimentação dos dentes remanescentes, assim como no seu uso protético definitivo após o término do tratamento ortodôntico propriamente dito.

Com base nestas conclusões obtidas, passou-se a admitir que os implantes instalados com objetivo primário de servirem como ancoragem ortodôntica poderiam ser submetidos a cargas mais precoces em relação àqueles inseridos para reabilitação oclusal, diminuindo o tempo de espera necessário. Alguns autores (ALDIKAÇTI et al., 2004; COCHRAN et al., 1998; OYONARTE et al., 2005b,2005a; ROBERTS et al., 1989; ROBERTS et al., 1984) testaram a aplicação de carga precoce (quatro semanas a seis semanas) sobre implantes para ancoragem ortodôntica, obtendo resultados favoráveis.

Com o aumento dos trabalhos relacionados à utilização de carga imediata sobre implantes para reabilitação (CEHRELI et al., 2005; ESPOSITO et al., 2007; GAPSKI et al., 2003; LORENZONI et al., 2003; MISCH 2004; MISCH et al., 2004a,2004b; NKENKE et al., 2005a; NKENKE et al., 2005b), julgamos válida a 
possibilidade da utilização de carga imediata sobre implantes que serão inicialmente utilizados para ancoragem ortodôntica, e posteriormente aproveitados para a reabilitação protética de pacientes.

\subsection{Carga imediata sobre implantes osseointegráveis}

O protocolo clássico descrito por ADELL et al. (1981) determina que após a colocação de um implante osseointegrado este deva ser deixado de 3 a 6 meses sem receber carga, para cicatrização adequada e boa integração entre tecido ósseo e implante. Isso porque, micromovimentos causados por forças ao redor da superfície osso-implante durante a fase de reparação poderiam induzir à formação de um tecido fibroso e causar a perda do parafuso. Após um longo período, considerado de aprendizado sobre o protocolo clássico da osseointegração, no qual estudos clínicos de longa duração comprovaram excelentes resultados e o conhecimento mais profundo da osseointegração, alguns autores começaram a publicar suas experiências com implantes submetidos à função imediata (ESPOSITO et al., 2007; NKENKE et al., 2005a; NKENKE et al., 2005b).

No início, a função imediata era utilizada apenas na reabilitação de mandíbulas totalmente desdentadas. Posteriormente iniciou-se a sua aplicação nas maxilas, sendo estas de indicação mais complexa que a mandíbula, pois apresentam osso geralmente menos denso e maior envolvimento com estética e fonética (GAPSKI et al., 2003; MISCH et al., 2004a,2004b).

A reabilitação de áreas parcialmente edêntulas e de perdas unitárias, com implantes osseointegráveis submetidos à carga ou função imediata, é considerada de maior complexidade ainda, pois a prótese deve apresentar contornos similares aos dentes adjacentes, restabelecendo de maneira eficaz a estética, a fonética e a função (LORENZONI et al., 2003).

Branemark iniciou os estudos sobre função imediata em 1980, nos quais afirmou que, na região da interface entre tecido ósseo e titânio, não devem ocorrer micromovimentos maiores que $20 \mu \mathrm{m}$, e que, devido à capacidade do osso da mandíbula de receber carga, os implantes deveriam permanecer rigidamente 
conectados, imediatamente após a sua instalação, além de posicionados com extrema precisão topográfica (FRANCISCHONE JR et al., 2006).

O conceito de função ou carga imediata vem sendo melhor compreendido e hoje é considerado uma alternativa segura de tratamento na reabilitação de pacientes total ou parcialmente edêntulos (BIJLANI; LOZADA, 1996; BUSER et al., 1988; CHIAPASCO et al., 1997; COLOMINA, 2001; COOPER et al., 2001; RANDOW et al., 1999; SALAMA et al., 1995).

A maioria destes estudos demonstrou a mesma taxa de sucesso quando comparados os implantes submetidos à carga imediata aos implantes que seguiram o protocolo tradicional. Contudo, estes resultados não significam que o protocolo clássico não será mais executado. Dados obtidos a partir de estudos recentes (ESPOSITO et al., 2007; GAPSKI et al., 2003; MISCH et al., 2004a, 2004b) demonstram que existem fatores que indicam a possibilidade de utilizar a carga imediata sobre implantes. Estes fatores podem ser divididos em 4 categorias: (1) fatores relacionados à cirurgia - estabilidade primária e técnica cirúrgica; (2) fatores relacionados ao hospedeiro - qualidade e quantidade de tecido ósseo cortical e trabecular, reparação, atividade de remodelação óssea; (3) fatores relacionados ao implante - desenho, superfície, dimensão; e (4) fatores oclusais - qualidade e quantidade de forças e desenho da prótese (GAPSKI et al., 2003).

É importante destacar os conceitos de estabilidade primária e secundária como critérios importantes na realização da função imediata. A estabilidade primária, que é mecânica, é fundamental para a indicação de carga imediata, estando relacionada ao ato cirúrgico, à geometria do implante, à excelência da técnica cirúrgica e à densidade óssea. A estabilidade secundária é um complemento da estabilidade primária, e possui aspectos biológicos relacionados às respostas dos tecidos, à cirurgia e ao implante, além do próprio processo de reparação óssea (GAPSKI et al., 2003; MISCH et al., 2004a).

A carga imediata sobre parafusos metálicos inseridos nos maxilares é comumente praticada em Cirurgia Ortognática e Traumatologia. Nesses casos, uma vez inseridos, os parafusos de fixação recebem carga imediata por meio da função. Além disso, com o advento da distração osteogênica, os parafusos recebem forças intensas apenas alguns dias após sua inserção. Porém, estes parafusos são úteis por um curto período de tempo, e depois podem ser removidos. Em função disso, 
estudos sobre o comportamento do tecido ósseo adjacente a esses dispositivos não têm sido motivo de interesse. Ao contrário, implantes inseridos para reabilitação ou ancoragem ortodôntica têm sido exaustivamente estudados (MELSEN; COSTA, 2000).

Assim, o presente trabalho objetiva avaliar o uso de carga ortodôntica imediata sobre implantes convencionais, com vistas a diminuir o tempo de tratamento de pacientes que necessitem desta modalidade de ancoragem, além de investigar a viabilidade destes implantes para posterior reabilitação protética.

\subsection{O minipig como modelo experimental}

A pesquisa médico-odontológica tem se desenvolvido com uma importante contribuição dos estudos em animais. Essa prática continua sendo largamente empregada com o intuito de se desenvolver métodos e técnicas que possam gerar instrumentos de "cura" ou alívio para os males que acometem o homem e outros animais (MARIANO, 2003).

Dentre várias espécies utilizadas em experimentação biomédica destacase o suíno doméstico (Sus scrofa domesticus). Originário da Europa e Ásia, este animal foi introduzido na América por Colombo em 1493. Descendente do javali, o suíno é um mamífero onívoro, de tamanho médio e corpo robusto, explorado em cativeiro há mais de cinco mil anos. Atinge a puberdade em média entre os 5 e 6 meses de idade, quando então está pronto para a reprodução. É um animal sociável que vive em grupo (MACHADO, 1967; SISSON; GROSSMAN, 1959).

O uso do suíno em pesquisas científicas é uma prática antiga (SWINDLE, 1988; SWINDLE et al., 1992). No ano de 1540, VERSALIUS, em sua famosa obra De Humani Corporis Fabrica, em que tentava descrever os mecanismos que regem o corpo humano, desenhou um suíno sendo utilizado em experimentação da maneira como o médico grego Galeno o fizera há mais de mil anos. Segundo o autor, essa deve ser a mais antiga ilustração do uso desses animais nas diferentes áreas da ciência.

HAVEY, em 1628, ao descrever os mecanismos que regem a circulação sangüínea, também utilizou o suíno como animal de experimentação para melhor 
compreender a fisiologia humana. Os estudos de Versalius e Havey contribuíram para que Claude Bernard escrevesse mais tarde as normas da medicina experimental, que regem os procedimentos experimentais em biologia e medicina em nossos dias (MARIANO, 2003).

Apesar dessas evidências, bem como daquelas que mostram a utilização de suínos de longa data na experimentação animal, o uso desta espécie como modelo experimental pela comunidade científica foi acanhado até 1970 (MARIANO, 2003).

A restrição do uso de suínos se prendeu à elevada capacidade de conversão alimentar com conseqüente ganho de peso desses animais, limitando o planejamento de experimentos em longo prazo. Por essa razão, suínos com essas características eram utilizados apenas em experimentos agudos ou de curta duração. Ainda, a utilização de animais muito jovens (leitões desmamados) induz a resultados não comparáveis à fisiologia de humanos adultos (MARIANO, 2003).

As limitações descritas acima levaram cientistas a desenvolver linhagens de suínos com dimensões compatíveis com a utilização dos mesmos em laboratório, facilitando assim o emprego destes animais como modelo de experimentação em diversas áreas da pesquisa médico-biológica. Esses animais foram denominados de miniporcos (minipigs) ou, dependendo das dimensões dos mesmos, suínos miniatura (miniature pigs). A partir do desenvolvimento dos minipigs, as principais desvantagens dos estudos em suínos foram eliminadas, como o rápido crescimento e ganho de peso, além do alto custo para manutenção dos animais (MARIANO, 2003), favorecendo o início do desenvolvimento de diversas pesquisas (MCKEAN et al., 1971; WEAVER et al., 1966,1969).

O estudo programado para o desenvolvimento de uma população de suínos miniatura iniciou-se no Instituto Homel, da Universidade de Minesota, em 1949 (ENGLAND et al., 1954). Resultados apresentados em 1965 e estudos nos 20 anos subseqüentes substanciaram os objetivos de se produzir um animal de tamanho reduzido, anatômica e fisiologicamente normal. Publicações recentes indicam que a seleção genética para um tamanho reduzido continua em várias linhagens de suíno miniatura, incluindo o suíno Kangaroo Island, do sul da Austrália; - Yucatan, originário do sul do México; o Minesota e o Sinclair, produzidos nos Estados Unidos; e o Goettinger, produzido na Dinamarca (MARIANO, 2003). 
É importante salientar que o plano de desenvolvimento do minipig foi feito para produzir animais que, mesmo em idade adulta, sejam suficientemente pequenos para permitir sua utilização como animal de laboratório em pesquisas biomédicas. Portanto, a única diferença entre o suíno doméstico e o minipig é o tamanho, não existindo diferenças entre os aspectos fisiológicos e anatômicos normais na sua similaridade com o homem (BUCK; WEAVER, 1965).

Segundo MARIANO (2003), a literatura referente ao uso do minipig em pesquisa biomédica mostra citação deste animal em inúmeras publicações nos últimos 30 anos. Realizamos uma busca bibliográfica na base de dados internacional PubMed, utilizando os seguintes descritores: "miniature swine or minipig or minipigs or miniature pig", e encontramos entre janeiro de 1950 e outubro de 2008, 4.985 trabalhos indexados. Como ilustra o gráfico, a utilização desses animais como modelo experimental nas diferentes áreas da biomedicina era pouco expressiva nas décadas de 50 e 60. A partir da década de 70, o número de publicações utilizando minipigs apresenta um crescimento significante e contínuo (Figura 1).

Figura 1: Graitco liustrando o crescimento do numero de pesquisas indexadas no PubMed utilizando o minipig como modelo experimental nas diferentes áreas da biomedicina

Estão hoje amplamente estabelecidas na literatura as semelhanças entre os suínos e o homem. O desenvolvimento embriológico do suíno tem sido reconhecido como muito similar ao encontrado em humanos, razão pela qual embriões de suínos têm sido utilizados para o estudo da embriologia humana. As semelhanças se estendem à anatomia (BUSTAD; MCCLELLAN, 1965; ENGLAND et al., 1954; HERRING, 1995; MARIANO, 2003; MCKEAN et al., 1971; PANEPINTO; PHILIPS, 1986; WEAVER et al., 1969; WEAVER et al., 1962), fisiopatologia (BUSTAD; MCCLELLAN, 1965; ENGLAND et al., 1954; WEAVER et al., 1969; WEAVER et al., 1962) e estrutura molecular (BUCK; WEAVER, 1965; BUSTAD; 
MCCLELLAN, 1965; ENGLAND et al., 1954; WEAVER et al., 1966; WEAVER; MCKEAN, 1965; WEAVER et al., 1962), as quais são muito menores quando a fisiologia do homem é comparada à do cão, rato, camundongo e outras espécies utilizadas em experimentação.

Os suínos, incluindo o minipig, apresentam semelhanças com o homem no que diz respeito a aspectos ligados à Odontologia (BUSTAD; MCCLELLAN, 1965). WEAVER; MCKEAN (1965) complementaram que os minipigs possuem atributos de um animal ideal para pesquisas na área odontológica: padrão de crescimento semelhante ao do homem; quantidade de crescimento rápida 0 bastante, para permitir a realização de estudos em determinado período de tempo, e lenta o bastante, que permite a diferenciação de determinadas etapas de um estudo; fisiologia semelhante à do homem, incluindo mastigação e movimentos da mandíbula; acesso aos dentes e glândulas para a realização de procedimentos clínicos e baixo custo de manutenção. Além disso, pesquisas direcionadas à Odontologia são facilitadas pela grande abertura bucal (WEAVER et al., 1962).

Os suínos são animais difiodontes, sendo a dentadura decídua formada por 32 dentes: 12 incisivos, 4 caninos e 16 molares; e a dentadura permanente formada por 44 dentes: 12 incisivos, 4 caninos, 16 pré-molares e 12 molares (MACHADO, 1967; SISSON; GROSSMAN, 1959). Para a determinação da idade durante os 12 primeiros meses de vida do suíno o melhor procedimento é a identificação de alguns dentes específicos que só irrompem após certa idade (MACHADO, 1967), o que foi estudado por alguns autores (MACHADO, 1967; SISSON; GROSSMAN, 1959).

A seqüência e cronologia de erupção dos dentes em minipigs foram estudadas por WEAVER; JUMP; MCKEAN $(1966,1969)$ para Pitman-Moore Minipigs. Esta seqüência foi confirmada para Minipigs BR-1 por OLTRAMARI et al. (2007c) num estudo radiográfico, com acompanhamento dos animais dos 3 aos 15 meses de idade. Segue a seqüência descrita pelos autores para Minipigs BR-1:

- 3 meses: estão irrompidos todos os incisivos, caninos e molares decíduos, com exceção do primeiro molar decíduo que já exfoliou e será substituído em breve pelo primeiro pré-molar. Já é possível visualizar radiograficamente os germes dos seguintes dentes permanentes: primeiros e terceiros incisivos, caninos, primeiros pré-molares e primeiros molares. 
- 5 meses: Os primeiros e terceiros incisivos e os caninos decíduos já se apresentam com bastante desgaste na coroa e raiz bastante reabsorvida; os segundos incisivos, que irromperam por último, apresentam-se praticamente intactos. Por volta dos 5 meses irrompem os primeiros pré-molares. Radiograficamente é possível visualizar os germes dos seguintes dentes permanentes: primeiros e terceiros incisivos, caninos, terceiros e quartos prémolares, primeiros e segundos molares permanentes.

- 7 meses: início do irrompimento dos primeiros molares permanentes. Radiograficamente é possível visualizar os seguintes germes dentários permanentes: primeiros e terceiros incisivos, caninos, terceiros e quartos prémolares e segundos molares.

- 9 meses: caninos decíduos quase totalmente reabsorvidos e caninos permanentes prontos para iniciar irrupção. Início da irrupção dos terceiros incisivos permanentes. Radiograficamente é possível visualizar os seguintes germes dentários permanentes: primeiros e segundos incisivos, caninos, segundos, terceiros e quartos pré-molares, segundos molares permanentes e o início da formação dos terceiros molares.

- 12 meses: primeiros incisivos decíduos apresentam suas raízes bastante reabsorvidas e radiograficamente visualizam-se os primeiros incisivos permanentes prontos para irromper. Início do irrompimento dos segundos molares permanentes. Os caninos mostram-se em irrupção. Radiograficamente é possível visualizar os germes dentários dos seguintes dentes permanentes: segundos incisivos, segundos, terceiros e quartos prémolares, segundos molares permanentes (aqueles que ainda não iniciaram o processo de irrupção) e terceiros molares permanentes (ainda em estágio precoce de formação).

- 14 a 15 meses: encontram-se irrompidos os terceiros incisivos, caninos, primeiros pré-molares, primeiros e segundos molares permanentes. Os primeiros e segundos incisivos decíduos ainda estão presentes, mas já é possível visualizar os sucessores permanentes em estágio avançado de desenvolvimento. Os terceiros pré-molares na maxila e os quartos prémolares na mandíbula estão em estágio de irrupção, e verifica-se radiograficamente a presença dos germes dos demais pré-molares. Os 
germes dos terceiros molares encontram-se em estágio um pouco mais avançado de desenvolvimento.

A articulação temporomandibular (ATM) e as Disfunções Temporomandibulares (DTMs) têm sido estudadas em suínos (CHEUNG et al., 2007; HERFORD et al., 2005; NAVARRO et al., 2008; NAVARRO et al., 2008; SINDELAR; HERRING, 2005; SINDELAR et al., 2003; THURMULLER et al., 2006; THURMULLER et al., 2002; WARD et al., 1990; ZOUHARY; FEINBERG, 2006). Isso porque as características da ATM humana não podem ser adequadamente simuladas por animais comuns de laboratório, uma vez que para testar a função normal da ATM o modelo deve possuir anatomia, oclusão, movimento mandibular e biomecânico comparáveis ao humano. Alguns desses critérios são violados por primatas não humanos, e todos são violados por roedores (ratos, camundongos e cobaias) e alguns animais da ordem dos carnívoros (gatos e cachorros) (HERRING, 1995).

A variação na morfologia e função da ATM em mamíferos é surpreendente, até mesmo com relação à presença ou não do disco articular (HERRING, 1995). As formas de todos os componentes da ATM variam e esta diferença está relacionada aos movimentos que ocorrem ao nível articular. Nos carnívoros, a ATM permite pouco ou nenhum movimento de protrusão. Assim, as superfícies que se articulam são congruentes e simulam uma dobradiça, e o disco articular é pouco espesso em toda sua extensão. Os roedores apresentam movimento protrusivo do côndilo. Porém, esse movimento de protrusão é muito mais extenso em relação ao que acontece nos humanos. Nas ovelhas e cabras, os côndilos apresentam-se côncavos, ao contrário dos humanos, nos quais os côndilos são convexos. Além disso, a mastigação nos coelhos e nos ungulados difere sobremaneira da mastigação em humanos. Nesses animais, os molares formam planos inclinados que controlam a direção do movimento de força. Nos humanos, as cúspides dos dentes inferiores são muito menos importantes, sendo a força da mastigação controlada pela musculatura (HERRING, 1995).

Com relação à morfologia e movimentos mastigatórios, a semelhança mais próxima à condição humana é encontrada nos primatas superiores não humanos (macacos) e, surpreendentemente, nos suínos. Os suínos são muito 
semelhantes, talvez mais parecidos com os humanos que os macacos quando se destacam os detalhes da anatomia do disco articular (HERRING, 1995).

Além da morfologia e movimentos mastigatórios, há que se considerar a participação dos músculos da mastigação. A direção e a magnitude da carga na ATM são produtos da ação dos músculos mandibulares. Nos roedores e coelhos, a força muscular possui resultante anterior, que coincide com a força resultante de mordida, anulando a carga sobre a ATM. Nos cães, a força muscular possui resultante bastante posterior em relação à ATM, resultando em carga muito acentuada na articulação. Já nos humanos, a força muscular apresenta resultante pouco posterior à ATM, excedendo a força de mordida e fazendo com que a ATM receba carga suave (HERRING, 1995).

Os primatas superiores e suínos são anatomicamente e funcionalmente mais semelhantes aos humanos e, considerando-se custo, tamanho e cooperação, recomenda-se a utilização dos suínos como modelos experimentais para desenvolver pesquisas nessa área (HERRING, 1995).

O suíno tem sido indicado como um bom modelo para pesquisas em Ortodontia (BUCHTER et al., 2006; BUCHTER et al., 2005; BUSTAD; MCCLELLAN, 1965,1968; FERRARI; HERRING, 1995; GIUNTA et al., 1995; HOLZHAUER et al., 1998; NOGUCHI et al., 1976; OLTRAMARI et al., 2007b; OLTRAMARI et al., 2007; VERNA et al., 2004; WEAVER et al., 1962; ZHANG et al., 1994).

Já na década de 70, NOGUCHI; KURODA; NAKAMURA (1976) relataram os aspectos de semelhança entre o homem e o suíno num trabalho de caracterização da linhagem Ohmini Minipigs. Afirmaram que a semelhança se refere à anatomia e fisiologia, e destacaram especialmente as similaridades relacionadas às estruturas bucais, o que permite o desenvolvimento de pesquisas científicas ligadas à Odontologia, inclusive estudos que envolvam Ortodontia, como a movimentação dentária e o crescimento e desenvolvimento craniofacial.

$\mathrm{Na}$ Implantodontia, os minipigs têm sido freqüentemente utilizados para pesquisa (BÜCHTER et al., 2005; MEYER et al., 2004; NEUGEBAUER et al., 2006; NKENKE et al., 2005a; NKENKE et al., 2005b; NKENKE et al., 2003; RIMONDINI et al., 2005; SCHIERANO et al., 2005). Nestes vários estudos, o minipig demonstrou ser um bom modelo experimental, apresentando recuperação rápida e eficiente após procedimentos cirúrgicos, mesmo quando estes foram extremamente invasivos. 
Objetivando a utilização de minipigs para pesquisa odontológica no Brasil, NAVARRO et al. (2007) desenvolveram seis técnicas para padronização radiográfica em Minipigs BR-1: técnica para avaliação da região posterior na maxila, técnica para avaliação dos dentes posteriores na mandíbula, técnica para avaliação dos dentes posteriores e anteriores na maxila, técnica para avaliação dos dentes posteriores na mandíbula (lateral oblíqua), técnica para avaliação dos dentes anteriores na maxila e técnica para avaliação dos dentes anteriores na mandíbula. Foram testados diferentes ângulos de incidência, distâncias focais e tempos de exposição aos raios X. A partir de então, foram confeccionados posicionadores específicos para as técnicas, na tentativa de facilitar a realização das radiografias e garantir a padronização dos resultados em estudos que envolvessem o controle radiográfico de vários animais, em longo prazo.

Em função da extensa literatura à cerca da utilização de minipigs como modelos experimentais para pesquisas na área médico-odontológica, optamos por utilizar este animal para nosso estudo investigativo. 

3. Proposição 



\section{PROPOSIÇÃO}

O objetivo deste estudo é testar, a partir das análises clínica, radiográfica e histológica, a seguinte hipótese nula: "Não há diferença para a perda óssea ao redor de implantes osseointegráveis mantidos sem carga durante período de reparo de 120 dias, implantes submetidos a interferências oclusais e implantes que receberam carga imediata para ancoragem ortodôntica". Para tanto, serão investigados a taxa de sucesso, a perda óssea em altura, a interação osso-implante e as características do tecido ósseo ao redor dos implantes osseointegráveis para estes três protocolos. 



\section{Material e}

\section{Métodos}





\section{MATERIAL E MÉTODOS}

A execução desta pesquisa foi aprovada pela Comissão de Ética no Ensino e Pesquisa em Animais (CEEPA), da Faculdade de Odontologia de BauruUSP, em 15 de dezembro de 2006 - processo no 21/2006.

\subsection{Material}

\subsubsection{Animais}

Para a realização deste estudo utilizaram-se 12 minipigs (Minipig BR-1®, Minipig Comércio e Desenvolvimento, Campina do Monte Alegre, SP, Brasil), machos, adultos jovens, com peso médio de $35 \mathrm{Kg}$ e 15 meses de idade. Os animais permaneceram no Biotério da Faculdade de Odontologia de Bauru-USP.

Durante o período experimental, os animais receberam água sem restrições e foram alimentados com ração própria para suínos (S4®), Bravisco, Bastos, SP, Brasil), numa quantidade diária equivalente a $2 \%$ do peso de cada animal, dividida em duas porções, uma pela manhã e outra à tarde. No período póscirúrgico, misturou-se a ração com água para que adquirisse consistência pastosa antes de ser ingerida pelos animais, para facilitar a alimentação. Os animais foram mantidos em baias com dimensões de $1,5 \mathrm{~m} \times 5 \mathrm{~m}$, sendo dois em cada baia (Figuras $2 \mathrm{~A}$ e B).
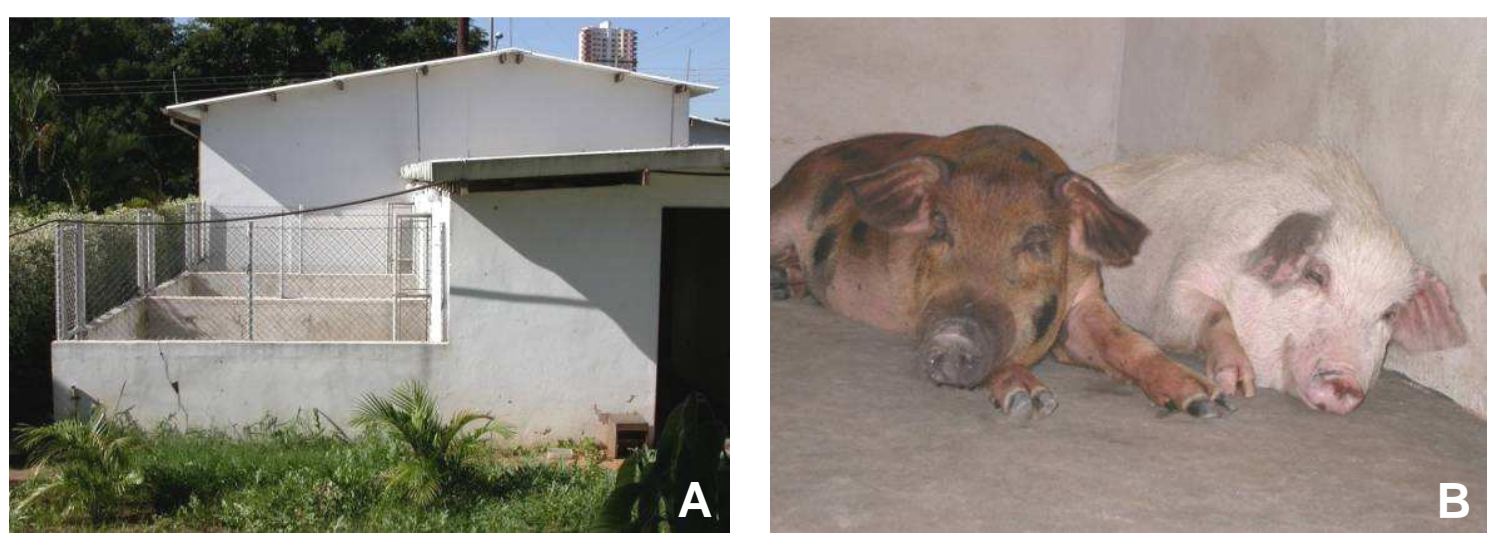

Figuras 2 A e B: Biotério da FOB-USP: setor das baias, no qual os animais permaneceram durante a pesquisa 
O local foi mantido sob iluminação natural e temperatura ambiente, exceto após as intervenções, quando, então, a baia em que os animais estavam era aquecida por meio de um aquecedor elétrico, até que os mesmos se recuperassem da anestesia geral. As baias eram higienizadas duas vezes ao dia e mantidas arejadas, permitindo total controle e observação dos animais.

\subsubsection{Implantes Osseointegráveis}

Nesta pesquisa, utilizaram-se 70 implantes experimentais (Exopro LA®, Bauru, SP, Brasil) fabricados com titânio comercialmente puro Grau 2, com dimensões de $8,5 \mathrm{~mm}$ de comprimento da rosca e $3,75 \mathrm{~mm}$ de diâmetro.

Havia dois tipos de implantes:

- Implantes osseointegráveis de plataforma regular - implantes sepultados, com a base inferior da plataforma dos implantes posicionada ao nível da crista óssea; após a inserção, instalava-se o parafuso de cobertura e realizava-se o recobrimento total dos implantes por meio da realização de sutura (Figura 3A);

- Implantes osseointegráveis de plataforma regular com corpo único - possuíam em uma única peça o implante e o intermediário unidos, e desta forma, após a instalação, a base inferior da plataforma do implante permanecia ao nível da crista óssea e o intermediário ficava exposto à cavidade bucal; o intermediário possuía um orifício que possibilitava a utilização de acessórios nos grupos que receberam carga ortodôntica (Figura 3B).
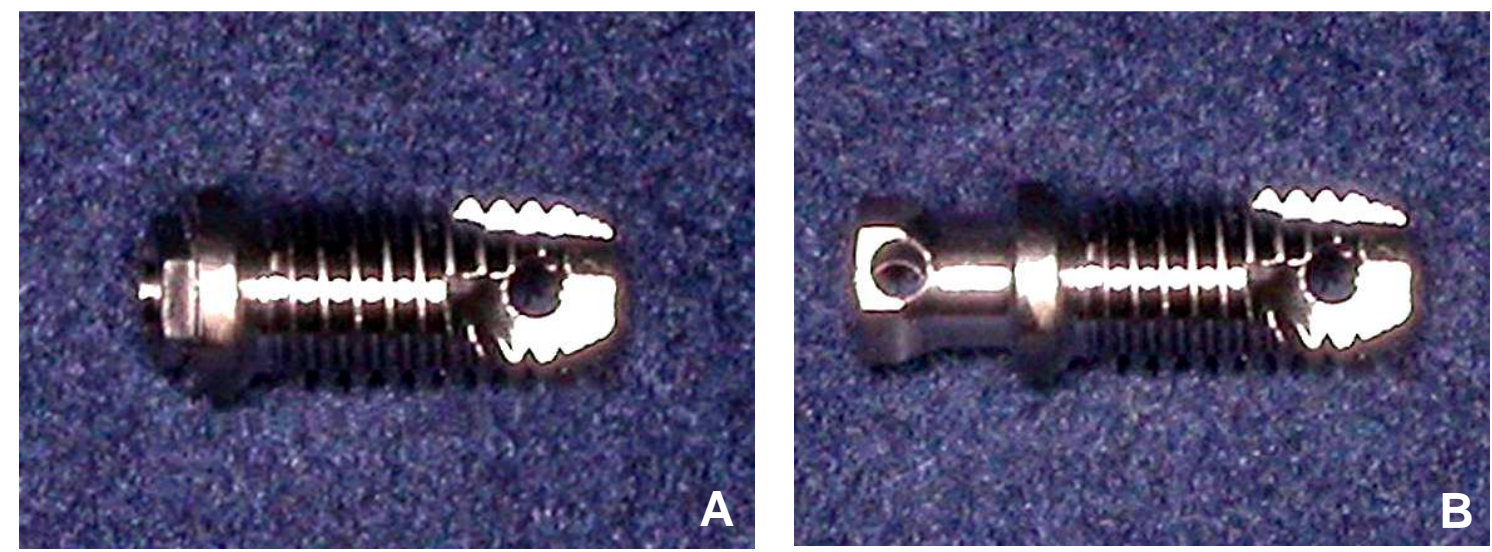

Figuras 3 A e B: A) Implantes osseointegráveis de plataforma regular; B) Implantes osseointegráveis de plataforma regular com corpo único 


\subsubsection{Divisão dos Grupos}

Grupo 1 (n=12): implantes osseointegráveis de plataforma regular, sepultados na região mesial dos caninos, sendo 6 na maxila e 6 na mandíbula, sem carga;

Grupo 2 ( $n=6)$ : implantes osseointegráveis de plataforma regular, sepultados na região de extração dos primeiros pré-molares, sendo 3 na maxila e 3 na mandíbula, sem carga;

Grupo 3 (n=12): implantes osseointegráveis de plataforma regular com corpo único, instalados na região mesial dos caninos, sendo 6 na maxila e 6 na mandíbula, expostos a interferências oclusais imediatamente após sua inserção;

Grupo 4 ( $n=20)$ : implantes osseointegráveis de plataforma regular com corpo único, instalados na região mesial dos caninos, sendo 10 na maxila e 10 na mandíbula, expostos à carga ortodôntica imediata e sem interferências oclusais;

Grupo $5(\mathrm{n}=20): 20$ implantes osseointegráveis de plataforma regular com corpo único, instalados na região de extração dos primeiros pré-molares, sendo 10 na maxila e 10 na mandíbula, expostos à carga ortodôntica imediata e sem interferências oclusais.

\subsection{Métodos}

\subsubsection{Contenção dos Animais}

A contenção dos animais antes das intervenções constitui uma etapa extremamente importante do experimento. Este fato é relevante principalmente quando se considera a utilização de suínos em pesquisas, animais que se tornam facilmente estressados, o que pode dificultar os procedimentos no que diz respeito à sedação deste animal e estabilidade durante todo o tempo de trabalho.

Por isso, o manejo adequado dos animais durante a captura para iniciar os procedimentos de anestesia é o primeiro passo para se obter sucesso nas intervenções. Para esta pesquisa, desenvolvemos um dispositivo composto por três roldanas interligadas por corda e uma rede, para o qual o animal era conduzido e 
então suspenso, de maneira a impedir que ele pudesse ter algum tipo de apoio com as patas traseiras e dianteiras, e dessa forma permanecesse imobilizado (Figura 4). Este sistema facilitou o manejo, uma vez que uma única pessoa foi capaz de realizar a contenção do animal com segurança e sem dispor de muita força; além disso, foi possível manter o animal calmo, facilitando os procedimentos anestésicos.

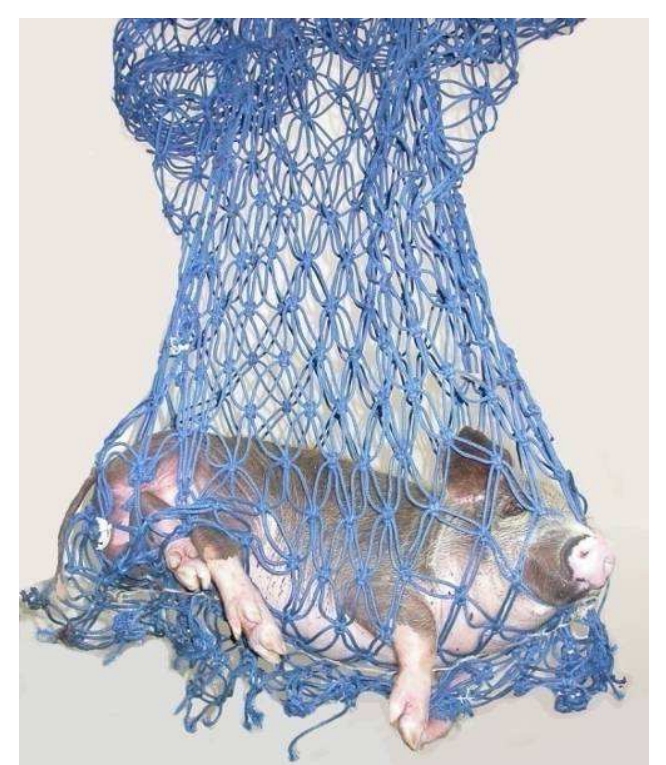

Figura 4: Contenção do animal, por meio de rede suspensa

\subsubsection{Anestesia dos Animais}

$\mathrm{Na}$ realização de todas as intervenções, os animais estavam sob anestesia geral. Para isso, eles permaneceram em jejum alimentar de 12 horas e jejum hídrico de 6 horas previamente aos procedimentos anestésicos (MASSONE, 1994; SWINDLE, 1994).

Após a contenção do animal, utilizou-se a combinação de pré-anestésico específico para suínos Azaperone (Destress ${ }^{\circledR}$ - Des-Vet, São Paulo, SP, Brasil), ministrando-se via intramuscular $1 \mathrm{mg} / \mathrm{Kg}$ de peso. Após 20 minutos, aplicou-se a dose inicial de anestésico geral Quetamina (Dopalen® - Vetbrands, Jacareí, SP, Brasil), com dosagem de $5 \mathrm{mg} / \mathrm{Kg}$ de peso, também por via intramuscular. Estes dois medicamentos foram aplicados enquanto o animal estava na rede de contenção.

Aproximadamente após 10 minutos da aplicação do anestésico geral, ocorria o aprofundamento da anestesia e o animal era levado ao laboratório de 
pesquisa, onde foram realizadas as cirurgias. No laboratório, iniciavam-se os procedimentos para dar continuidade à anestesia, por via endovenosa pela veia marginal da orelha (Figuras 5 A-D).
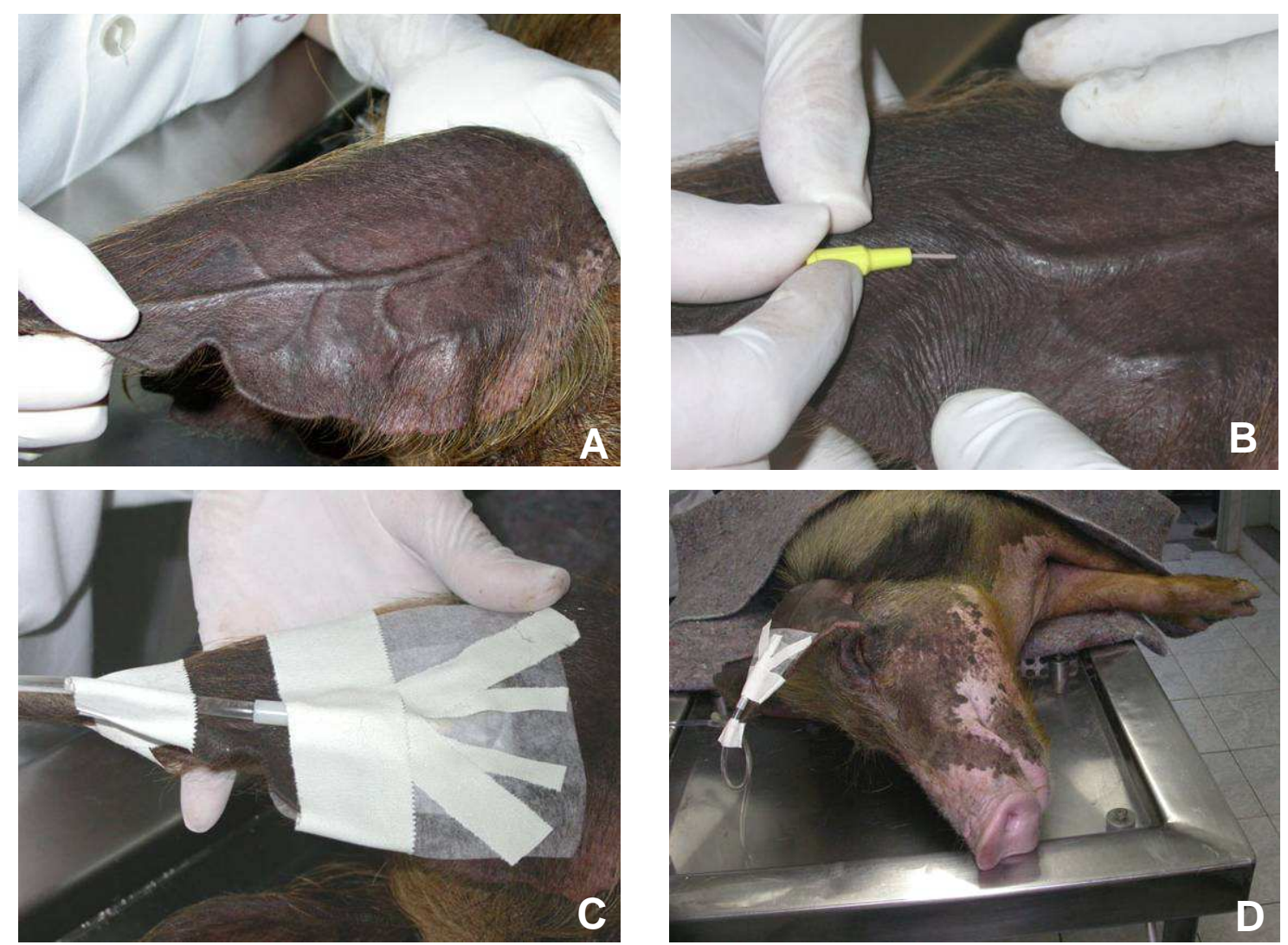

Figuras 5 A-D: A) Veia marginal da orelha após tricotomia na região; B) Introdução do catéter; C) Catéter em posição e estabilizado; D) Animal na fase pré-cirúrgica em venóclise

A dose inicial permitiu um tempo de trabalho de aproximadamente 1 hora, quando então se iniciavam as reaplicações, que corresponderam à $5 \mathrm{mg} / \mathrm{Kg}$ de peso de Quetamina, realizadas a cada 30 minutos, enquanto durasse a intervenção, em média 3 horas. Durante todo o período em que o animal permaneceu sob anestesia geral, monitoraram-se os batimentos cardíacos, a freqüência respiratória e a temperatura, além do controle dos reflexos palpebrais, interdigitais e intestinais. Os animais foram mantidos com cobertas para controle da temperatura. 


\subsubsection{Preparo dos animais e procedimentos cirúrgicos}

A equipe foi composta por um cirurgião, um anestesista e um assistente (Figura 6).

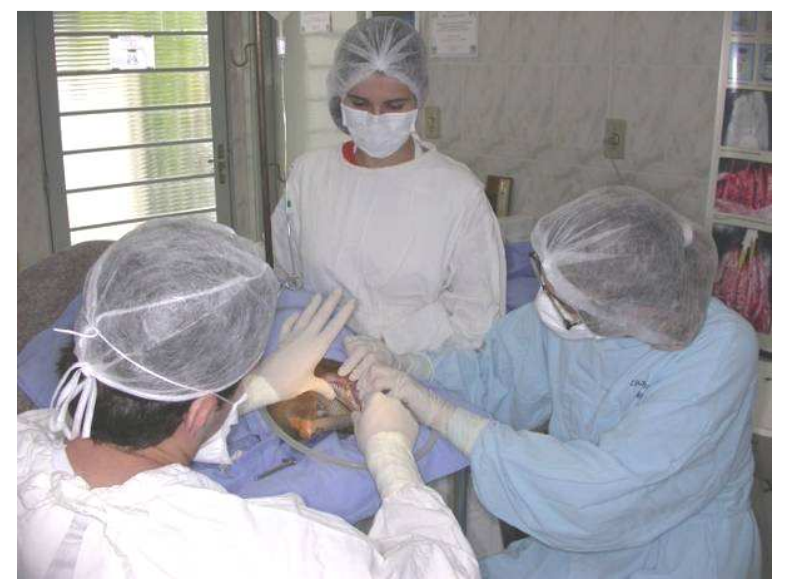

Figura 6 - Equipe atuando durante as intervenções

Para todos os animais, seguiu-se a mesma seqüência operatória. Inicialmente, os animais foram contidos e então mantidos sob anestesia geral conforme descrito anteriormente. Quando levados ao laboratório de pesquisa, os animais foram colocados sobre uma mesa cirúrgica, na qual permaneceram em posição lateral para o início da intervenção.

Todas as intervenções cirúrgicas foram executadas pelo mesmo cirurgião (RLN). Realizaram-se anti-sepsia intra (Figura 7A) e extrabucal (Figura 7B) com PVPI tópico (Polivinil Pirrolidona-lodo), seguidas pela irrigação com soro fisiológico. Os animais foram cobertos com campo operatório estéril, para o início do ato operatório (Figura 7C). Para anestesia local, realizou-se a técnica terminal infiltrativa, com solução anestésica à base cloridrato de lidocaína $2 \%$ e epinefrina 1:100.000 (Anestésico L® - Pearson, São Paulo, SP, Brasil), objetivando a ausência de dor e reflexos do animal e, ainda, a hemostasia local.

A seguir, realizou-se a incisão intrabucal (Figura 7D) da área em que seriam colocados os implantes envolvendo mucosa e periósteo, proporcionando o descolamento do retalho em espessura total (Figura 7E). Com a exposição do tecido ósseo, foram iniciados os procedimentos de fresagem para confecção do alvéolo cirúrgico. Nos grupos 2 e 5, realizou-se a extração dos primeiros pré-molares superiores e inferiores, antes da instalação dos implantes osseointegráveis (Figuras 7F e G). A seqüência de brocas seguiu o protocolo original descrito por Adell et al. (1981), onde o alargamento do alvéolo cirúrgico foi realizado progressivamente até 0 
diâmetro final de 3mm. Dessa forma, empregaram-se as seguintes brocas: esférica de $2 \mathrm{~mm}$, cilíndrica de $2 \mathrm{~mm}$, piloto $2 / 3 \mathrm{~mm}$, cilíndrica de $3 \mathrm{~mm}$ e counter sink, independente do tipo de osso abordado. O preparo do alvéolo cirúrgico foi realizado em 2.000 rpm, sob contínua refrigeração com solução salina. A profundidade de fresagem foi de $8 \mathrm{~mm}$. A observação da anatomia óssea foi o fator determinante do direcionamento ideal do implante, uma vez que se procurou evitar fenestrações por vestibular e palatino. A seqüência da instrumentação, em baixa rotação (48 rpm), consistiu da inserção dos implantes utilizando o aparelho W\&H® (W\&H Dentalwerk, Bürmoos, Salzburg, Áustria), com torque de inserção de $40 \mathrm{~N} / \mathrm{cm}$ para todos os grupos (Figuras 7G e H). O parâmetro de nível de assentamento da fixação foi a altura da crista óssea circundante, ou seja, deixou-se a plataforma do implante ao nível da crista óssea, permitindo o total recobrimento das roscas.

Os implantes dos grupos 1 e 2 eram de plataforma regular (Figuras 3A e 7I), enquanto os implantes dos grupos 3, 4 e 5 eram de plataforma regular com corpo único (Figuras 3B e 7J). Os implantes de plataforma regular foram instalados seguindo o protocolo cirúrgico descrito acima, apenas com variação da instalação do parafuso de cobertura e recobrimento total de mucosa por meio da realização de sutura; já os implantes de plataforma regular com corpo único permaneciam com o intermediário exposto à cavidade bucal. A sutura foi realizada com fio Vicryl® 4-0 (Ethicon - Johnson \& Johnson, Piscataway, NJ, EUA) (Figuras 7K-L).

Após a realização das suturas, os implantes dos grupos 4 e 5 receberam carga por meio de molas helicoidais de tração de Níquel-Titânio, com $7 \mathrm{~mm}$ de comprimento (Morelli®, Sorocaba, SP, Brasil). A quantidade de ativação foi padronizada em $300 \mathrm{~g}$ de força, a qual foi conferida por meio de um dinamômetro previamente calibrado (Dentaurum $\AA$, Ispringen, Baden Württemberg, Alemanha) (Figuras 7M-N).

As faces dos implantes que receberam diretamente carga ortodôntica foram denominadas de lado de pressão, enquanto que as faces contrárias foram denominadas lado de tensão, conforme outros trabalhos na literatura (OYONARTE et al., 2005b,2005a). Esta nomenclatura foi mantida para os implantes que não receberam forças ortodônticas, para fins de padronização e com a intenção de permitir a tabulação dos dados e análise estatística.

Após o procedimento cirúrgico, administraram-se via intramuscular: antibiótico (Florfenicol - Nuflor®, Schering-Plough, Cotia, SP, Brasil, $1 \mathrm{ml}$ para cada 
$20 \mathrm{~kg}$ de peso, duas aplicações, com intervalo de 48 horas); corticosteróide (Triclorometiazida e Dexametasona - Naquasone® Injetável, Schering-Plough, 5ml por dia, durante 2 dias); antiinflamatório não esteroidal (Flunixin meglumine Banamine ${ }^{\circledR}$ Injetável, Schering-Plough, $2 \mathrm{ml}$ para cada 45 quilos de peso por dia, durante 3 dias); analgésico (dipirona sódica - D500, Pfizer, Guarulhos, SP, Brasil, $5 \mathrm{ml}$ por dia, durante 3 dias).

No período de recuperação da anestesia, o animal era posicionado em um dispositivo de contenção adaptado a partir de um equipamento para o manejo de eqüinos (cabresto). Posicionavam-se as patas dianteiras e a cabeça dentro do dispositivo e o animal era suspenso. Tanto a suspensão como a fixação inferior deste dispositivo eram feitas em quatro pontos, não permitindo que 0 animal pudesse causar ferimentos a si mesmo durante o pós-operatório imediato (Figura 70). Além disso, os animais receberam alimentação pastosa durante a primeira semana da fase pós-cirúrgica (Figura 7P).
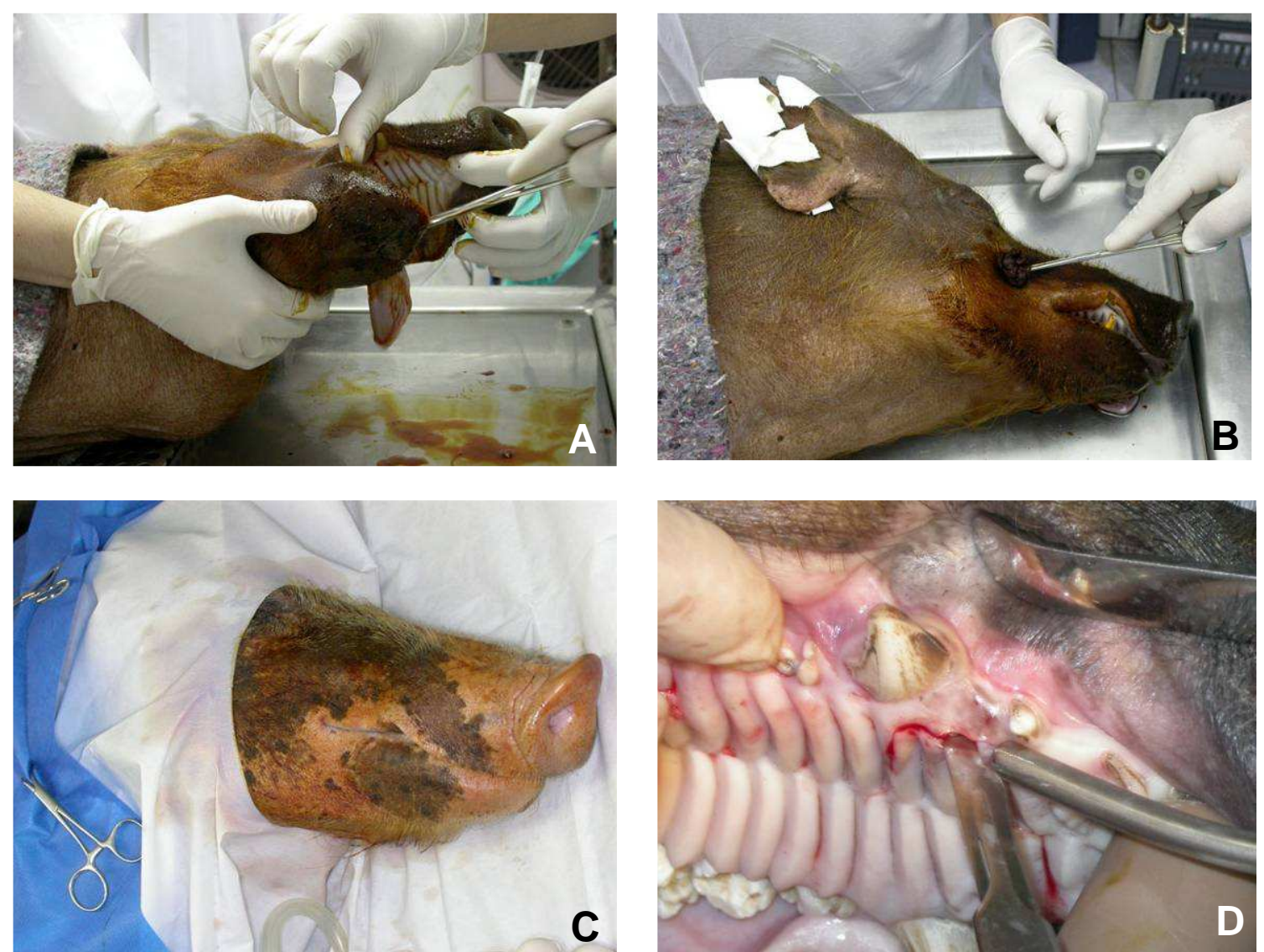

Figuras 7 A-D: A e B) Anti-sepsia intra e extrabucal com PVPI tópico; C) Animais cobertos com campos operatórios estéreis; D) Incisão intrabucal 

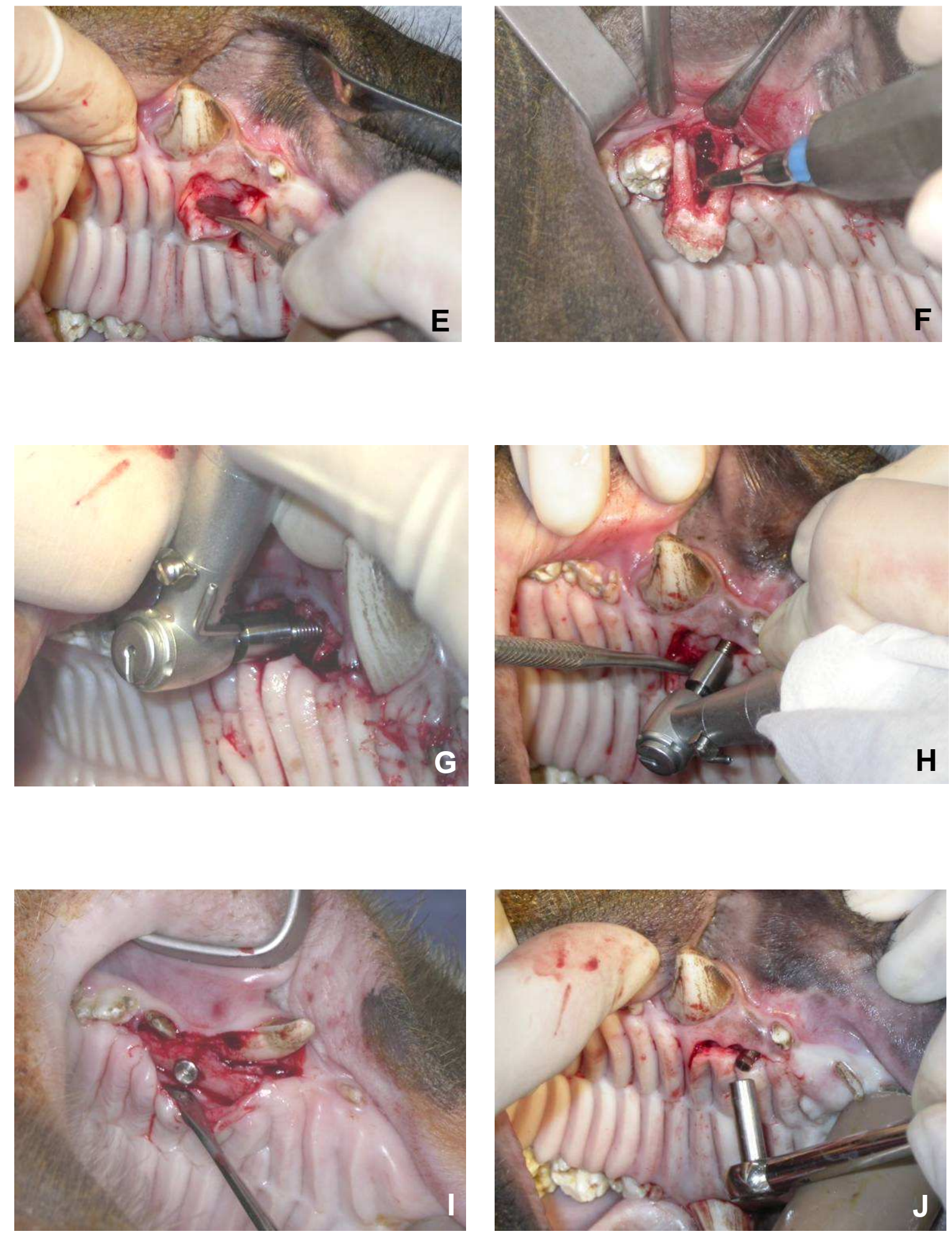

Figuras 7 E-J: E) Descolamento mucoperiostal; F) Extração dos primeiros prémolares; G) Instalação dos implantes osseointegráveis em área de extração do primeiro pré-molar; H) Instalação dos implantes osseointegráveis na região mesial dos caninos; I) Implantes osseointegráveis de plataforma regular em posição (sepultados); J) Implantes osseointegráveis com corpo único em posição (expostos) 

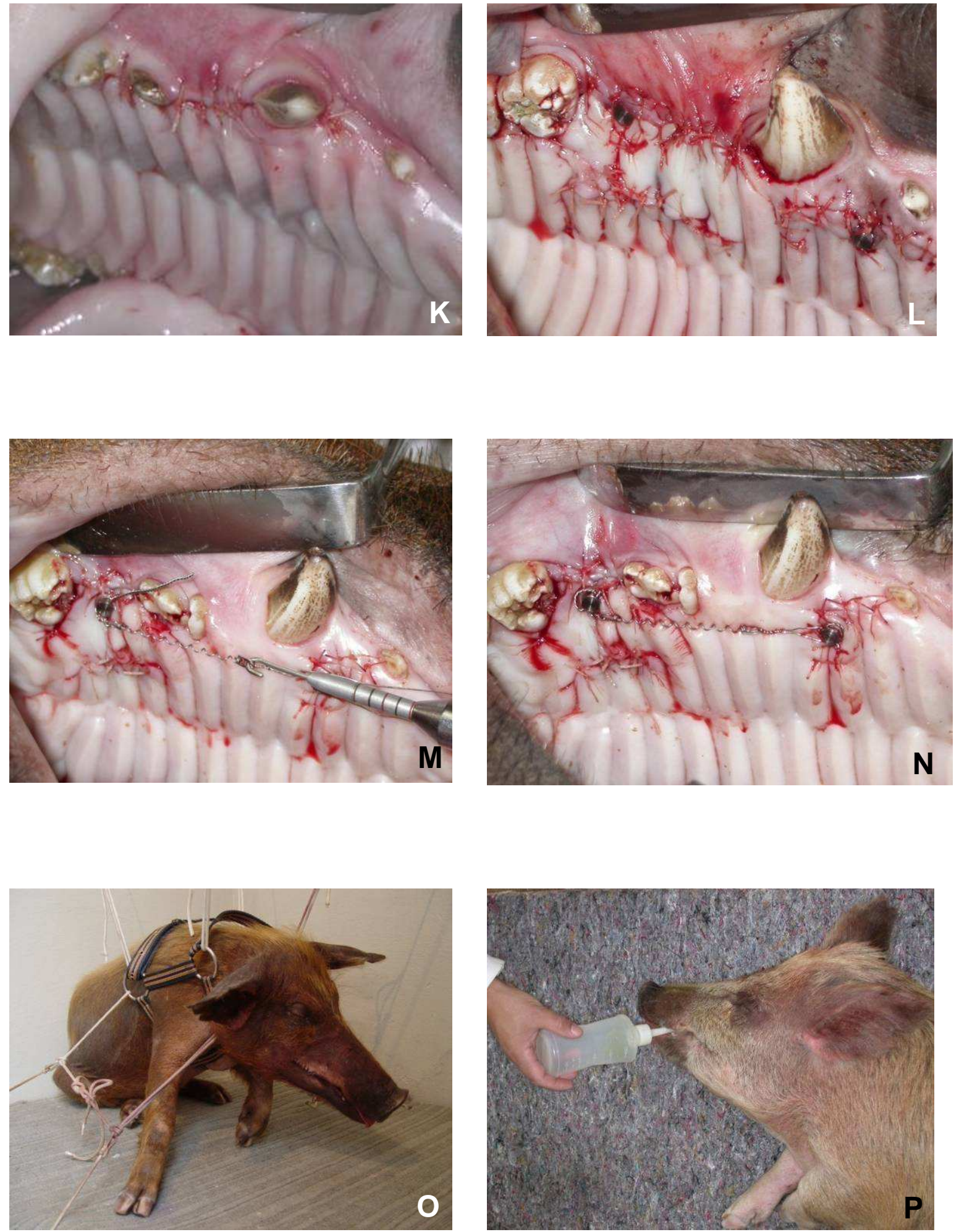

Figuras 7 K-P: (K) Coaptação das bordas e sutura sobre os implantes sepultados; (L) Coaptação das bordas e sutura nos implantes expostos; M) Mensuração da quantidade de força; N) Mola de secção fechada em posição; O) Pós-operatório imediato: animal estabilizado em um dispositivo para não se machucar; P) Alimentação pastosa na fase pós-cirúrgica 


\subsubsection{Obtenção das Radiografias}

Decorrido o período experimental (120 dias), os animais foram eutanasiados e realizaram-se imediatamente as tomadas radiográficas intrabucais. Com o propósito de manter o mesmo padrão em todas as tomadas radiográficas, seguiu-se o protocolo específico para Minipigs BR-1 descrito por NAVARRO et al. (2007), mantendo-se os mesmos ângulos, distâncias focais e tempos de exposição aos raios $\mathrm{X}$, assim como utilizado em outros estudos pelos mesmos autores (NAVARRO et al., 2007; OLTRAMARI et al., 2007b; OLTRAMARI et al., 2007c).

Realizaram-se duas das técnicas descritas:

\section{1) Técnica para avaliação da região posterior na maxila (Figuras $8 \mathrm{~A}$ e $\mathrm{B}$ )}

- Posição do animal: supina lateral;

- Filme: oclusal (Kodak, Emeryville, CA, EUA: IO-41, size 4);

- Colocação do filme: intrabucal, posicionado no palato e estabilizado pelo posicionador de resina acrílica, nos lados direito ou esquerdo;

Padronização: distância foco-filme $30 \mathrm{~cm}$, incidência do feixe de raios $\times 40^{\circ} \mathrm{e}$ tempo de exposição 1 segundo.

2) Técnica para avaliação dos dentes posteriores na mandíbula (Figuras $9 \mathrm{~A}$ e $\mathrm{B}$ )

-Posição do animal: supina lateral;

-Filme: periapical (Kodak: IP-01, size 2);

-Colocação do filme: intrabucal, utilizando o posicionador Han Shin ${ }^{\circledR}$ modificado na área a ser radiografada;

Padronização: distância foco-filme $35 \mathrm{~cm}$, incidência do feixe de raios $X 90^{\circ}$ com o filme e tempo de exposição 1 segundo. 

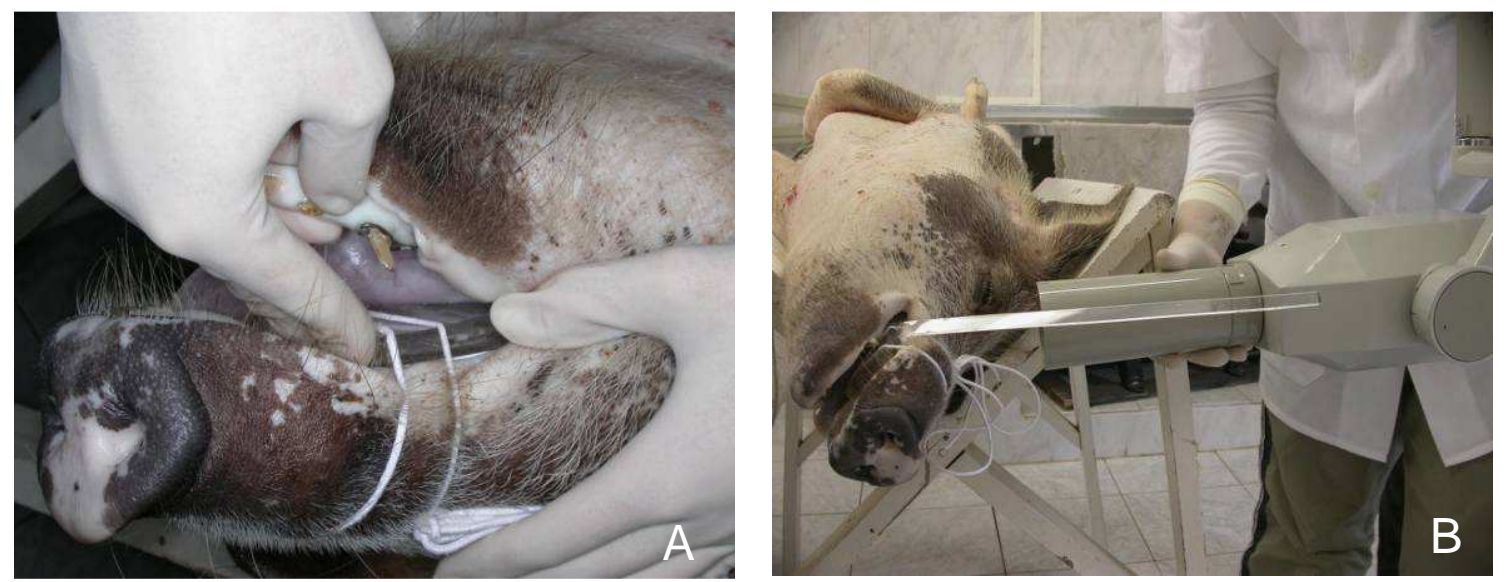

Figuras 8 A e B: Técnica para avaliação da região posterior na maxila: colocação do posicionador intrabucal para filme oclusal e posicionamento do cilindro localizador para a obtenção da radiografia
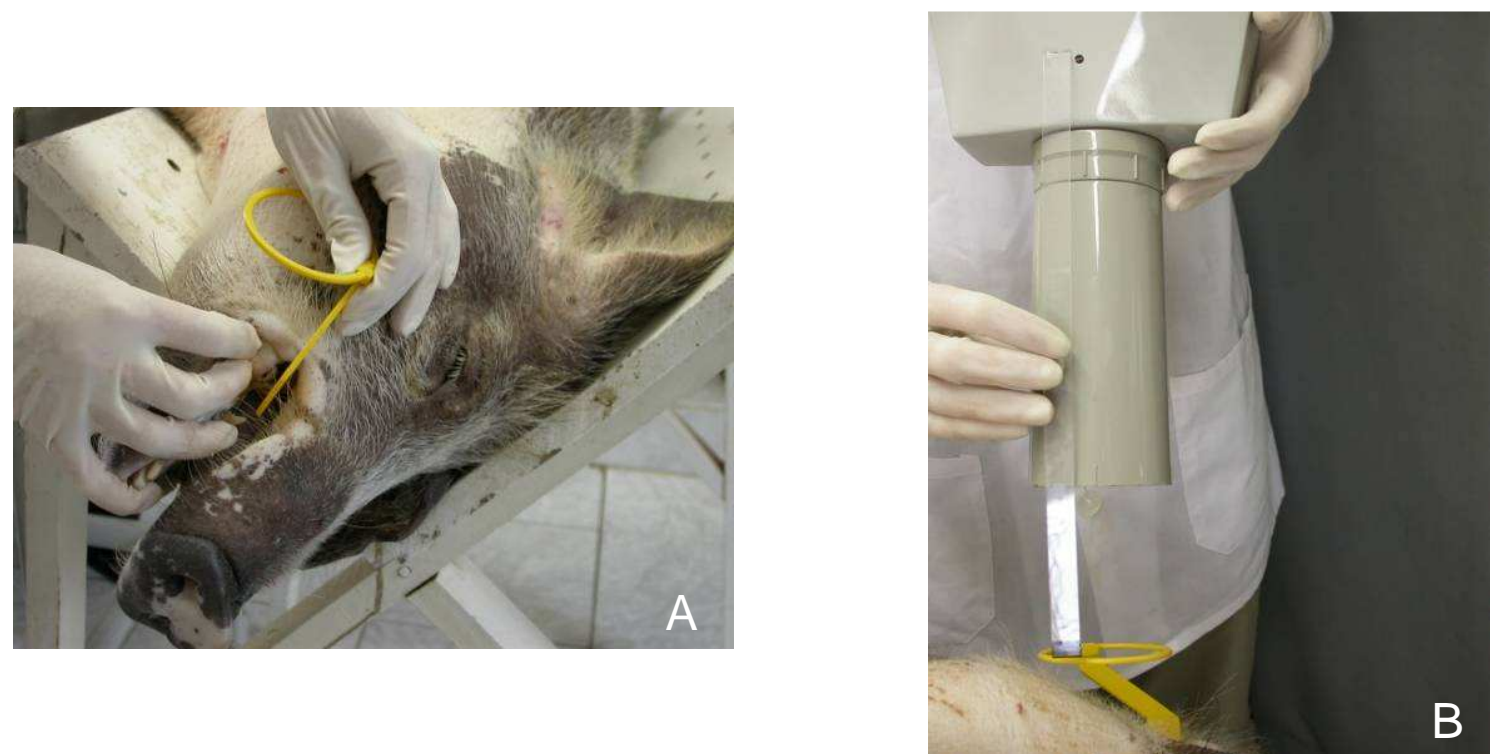

Figuras 9 A e B: Técnica para avaliação dos dentes posteriores na mandíbula: colocação do posicionador intrabucal para filme periapical e posicionamento do cilindro localizador para a obtenção da radiografia

Para a obtenção dos exames radiográficos desta pesquisa utilizou-se o aparelho de raios X Odontológico (Dabi 70x, Dabi Atlante $\AA$, Ribeirão Preto, SP, Brasil), calibrado com $50 \mathrm{kV}$ e $8 \mathrm{~mA}$. O processamento dos filmes foi manual, pelo método tempo/temperatura.

Realizaram-se tomadas radiográficas padronizadas nas áreas que receberam os implantes osteointegráveis (mesial de caninos superiores e inferiores, e região de pré-molares). 


\subsubsection{Obtenção das biópsias e preparo histotécnico}

Após a realização das tomadas radiográficas, os animais foram eutanasiados e decapitados, e segmentos da maxila e da mandíbula de interesse para a pesquisa foram fixados em solução de formol a $10 \%$ em tampão fosfato, por um período de sete dias. Após este período, as peças foram lavadas em água corrente durante 24 horas e mantidas em álcool $70 \%$, em temperatura de $4^{\circ} \mathrm{C}$, até o início do preparo histotécnico (SCHOU, 2003).

Iniciaram-se os processos de desidratação e infiltração, com o auxílio de um agitador (EXAKT 510 Dehydration \& Infiltration System, EXAKT, Norderstedt, Schleswig-Holstein, Alemanha), em uma série de banhos: 1ำ banho - álcool absoluto

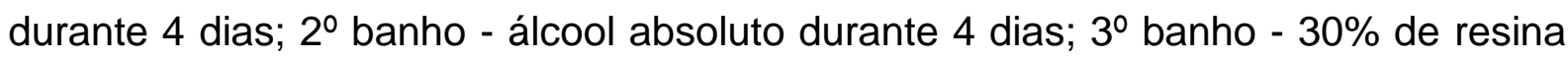
(Tecnnovitß 7200 VLC, Light-curing Embedding Resin, Heraeus Kulzer, Wehrheim, TS, Alemanha) $+70 \%$ de álcool etílico durante 4 dias; 4ํㅡㅁ banho - 50\% de resina (Tecnnovit@ 7200 VLC) + 50\% de álcool etílico durante 4 dias; 5ํanho - 100\% de resina (Tecnnovit@ 7200 VLC) durante 4 dias; 6 banho - 100\% de resina (Tecnnovit® 7200 VLC) durante 4 dias (Figura 10 A).

Após a seqüência de banhos, as peças foram armazenadas em um recipiente contendo resina (Tecnnovit@ 7200 VLC) e mantidas em máquina de vácuo durante 24 horas, para favorecer a infiltração. Em seguida, as peças foram colocadas, individualmente, em um molde próprio, embebidas em resina (Tecnnovit@ 7200 VLC) e polimerizadas durante 4 horas em luz amarela e 4 horas em luz azul na unidade de polimerização (EXAKT 520 Light Polymerization Unit, EXAKT) (Figura 10 B).

Após o processo de polimerização, os blocos foram aderidos a lâminas de acrílico (dimensões de 2 × 5 × 10mm, Emporium do Acrílico, Bauru, SP, Brasil), utilizando-se adesivo (Technovit 7230, Light-curing Fixation Adhesive, Heraeus Kulzer, Wehrheim-Alemanha) e um sistema de precisão (EXAKT 402, Precision Adhesive Press, EXAKT) (Figura $10 \mathrm{C}$ ). Após a fixação às lâminas, as peças foram cortadas em micrótomo para tecido duro (EXAKT Diamond Band Saw, EXAKT) (Figura 10 D) com fitas impregnadas por partículas de diamante (Diamond Cutting Band, 0,2 mm, D64, EXAKT) (Figura 10 E), em velocidade calibrada, até chegar à região de interesse para análise. 
Após esse corte, as peças passaram por um processo de polimento em equipamento próprio (EXAKT Grinding Systems, EXAKT), com lixas de granulação em ordem crescente, 800 (Grinding Paper K800, EXAKT), 1.200 (Grinding Paper K1200, EXAKT) e 2.000 (Polishing Paper P2000, EXAKT(Figura 10 F).

A superfície polida dos cortes foi, então, aderida a lâminas de acrílico menores (dimensões de 1,8 x 2,5 × 7,5mm, Emporium do Acrílico), utilizando-se adesivo (Technovit 7230) e um sistema de precisão (EXAKT 402). Após esta polimerização, as peças foram novamente cortadas em micrótomo para tecido duro (EXAKT Diamond Band Saw, EXAKT) com fitas impregnadas por partículas de diamante (Diamond Cutting Band, 0,2 mm, D64, EXAKT), em velocidade calibrada, até chegar à região de interesse para análise.

Removeram-se as lâminas de acrílico maiores (dimensões de 2 x $5 \times$ $10 \mathrm{~mm}$ ), e as superfícies ainda não polidas passaram, então, pelo processo de polimento em uma politriz (EXAKT Grinding Systems), com lixas de granulação em ordem crescente, 800 (Grinding Paper K800), 1.200 (Grinding Paper K1200) e 2.000

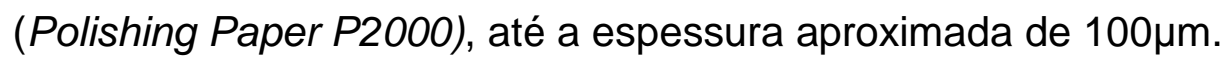

As lâminas foram coradas com Azul de Toluidina (Apêndice A1) e aderidas a lamínulas para análise. 

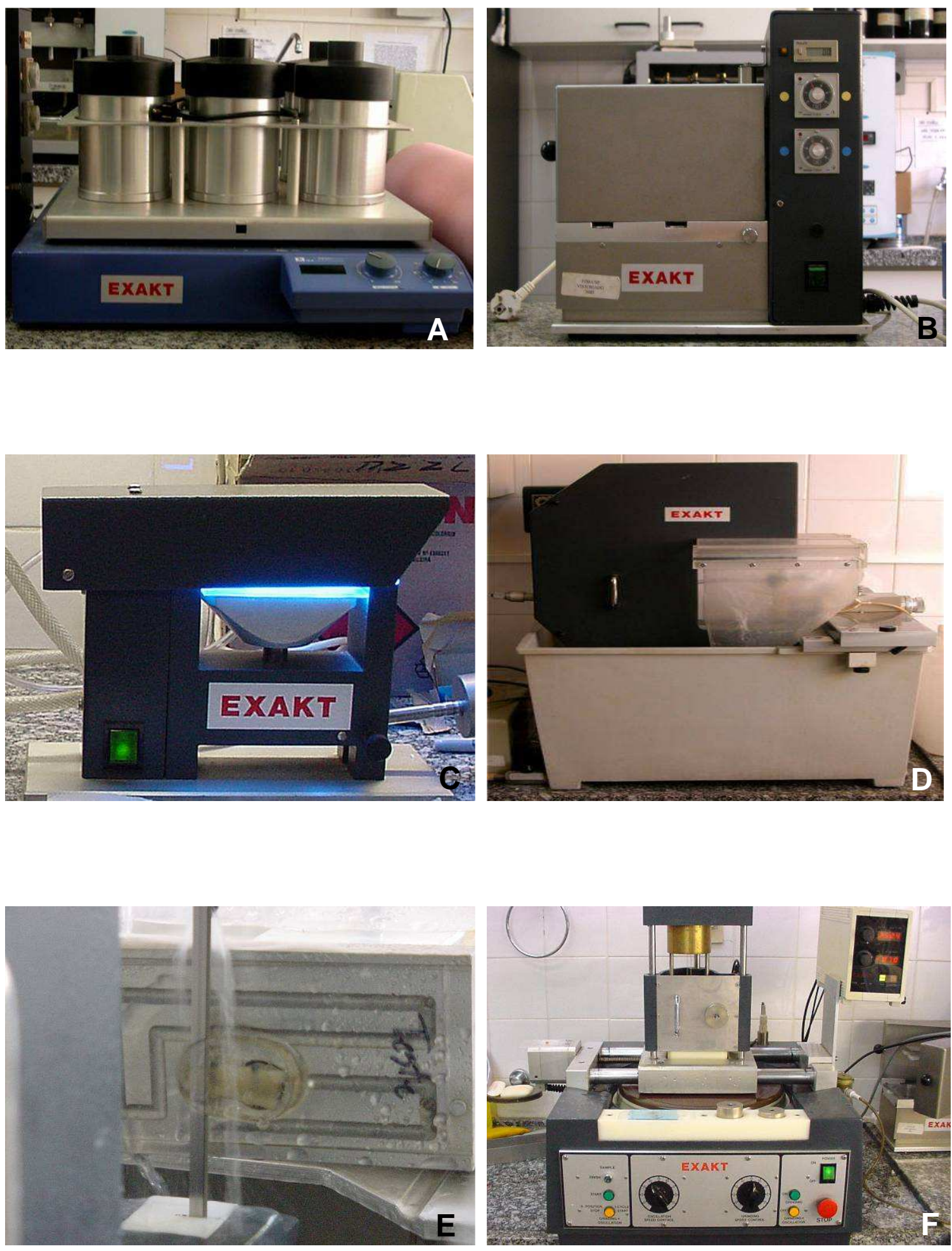

Figuras 10 A-F: A) Agitador (EXAKT 510 Dehydration \& Infiltration System, EXAKT; B) Unidade de polimerização (EXAKT 520 Light Polymerization Unit, EXAKT); C) Sistema de precisão para adesão das lâminas (EXAKT 402, Precision Adhesive Press, EXAKT); D) Micrótomo para tecido duro (EXAKT Diamond Band Saw, EXAKT); E) Fitas impregnadas por partículas de diamante (Diamond Cutting Band, 0,2 mm, D64, EXAKT) F) Politriz (EXAKT Grinding Systems) 


\subsubsection{Análise Clínica}

O Teste Exato de Fisher foi aplicado para avaliar estatisticamente a taxa de sucesso comparando todos os grupos entre si, considerando para cada grupo os implantes perdidos e os implantes que permaneceram clinicamente estáveis após o período de 120 dias. Além disso, demonstrou se havia diferença entre os implantes instalados na maxila e na mandíbula. Para este teste utilizou-se a Correção de Bonferroni, adotando-se então um nível de significância de 0,5\% para a comparação entre todos os grupos, e um nível de significância de 1\% para as comparações entre maxila e mandíbula.

\subsubsection{Avaliação radiográfica quantitativa da perda óssea}

Realizou-se a avaliação da quantidade de perda óssea, nos casos em que ela ocorreu, por meio sistema de análise de imagem digitalizada, composto pelo software Kontron KS300® (Kontron Eletronic GMBM - Carl Zeiss ${ }^{\circledR}$, Oberkochen, Baden-Wurttemberg, Alemanha) instalado em um computador IBM (Armonk, NY, EUA). Inicialmente, capturaram-se as tomadas radiográficas a partir do scanner Microtek SanMaker i800 (Microtek International, Cerritos, CA, EUA), utilizando o programa Scan Wizard 5.0, com 300dpi de resolução, e escala 100\%, no sistema para foto branco e preto. Em seguida as imagens foram transferidas para 0 programa $\mathrm{KS} 300 \AA$, onde se quantificou a perda óssea em altura.

A observação da altura óssea foi realizada nos lados direito e esquerdo dos implantes. Em todas as radiografias, padronizou-se o lado esquerdo como contrário à ação das forças (lado de tensão) e o lado direito como sendo o lado de ação das forças ortodônticas (lado de pressão), detalhe importante para a análise dos grupos 4 e 5 .

Nos casos em que não houve perda óssea perceptível ao exame radiográfico, foi atribuído o valor 0 . Nos casos em que houve perda óssea, a mesma foi quantificada nos lados direito e esquerdo do implante. Para a avaliação da perda óssea, traçou-se uma linha base na porção inferior da plataforma do implante, e partir desta linha base, traçaram-se duas linhas perpendiculares, uma do lado direito 
e outra do lado esquerdo, ambas posicionadas rente às roscas do implante, que terminavam ao nível ósseo visualizado pelo examinador (PVPO) (Figura 11).

Os valores destas retas deram-se em número de pixels, e como a medida do filme radiográfico era previamente conhecida e todas as radiografias foram capturadas utilizando-se a mesma escala, o valor em pixels pôde ser transformado em milímetros ( $\mathbf{1}$ pixel $=\mathbf{0 , 0 4} \mathrm{mm}$ ), para avaliação clínica dos valores obtidos. Estas medidas foram refeitas pelo examinador (PVPO) trinta dias após a primeira leitura, para assim comprovar a eficácia da metodologia.

Para a realização das mensurações, os arquivos contendo as radiografias de cada animal foram renomeados, para permitir avaliação cega, uma vez que desta forma o examinador não saberia a que grupo cada implante pertencia.

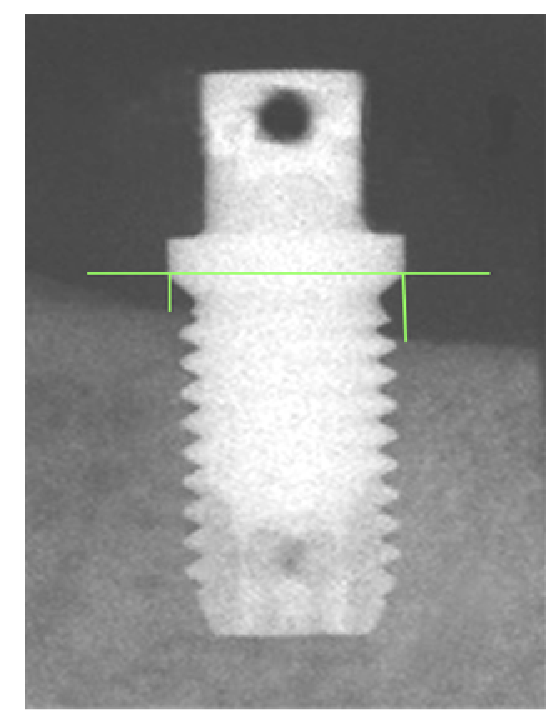

Figura 11: Sistema de análise de imagem KS300® utilizado para a avaliação da perda óssea em milímetros ao redor dos implantes

Para avaliação do erro intra-examinador, 30 dias após a primeira medição realizaram-se novamente as duas medidas nas cinqüenta e cinco radiografias, de ambos os grupos. A aplicação da fórmula proposta por DAHLBERG (1940) $\left(\mathrm{Se}^{2}=\right.$ somatória $\left.\mathrm{d}^{2} / 2 \mathrm{n}\right)$ permitiu estimar a ordem de grandeza dos erros casuais. $A$ obtenção dos erros sistemáticos procedeu-se pela aplicação do Teste t pareado, de acordo com HOUSTON (1983).

Erro Casual $=\sqrt{ } \underline{\sum d^{2}}$ onde, $\quad \mathrm{d}=$ diferença entre $1^{\underline{a}}$ e $2^{\underline{a}}$ medições $2 n$ $\mathrm{n}=$ número de radiografias remedidas 


\subsubsection{Análise estatística comparativa entre os grupos}

Os resultados quantitativos obtidos foram testados estatisticamente pela Análise de Variância (ANOVA), seguida pelo teste de Tukey, que possibilitou demonstrar se havia diferença entre os grupos no que se refere à perda óssea em altura. Para esta análise adotou-se um nível de significância de 5\%. Para a realização deste teste consideraram-se apenas os implantes que permaneceram clinicamente estáveis após 120 dias.

Todos os testes estatísticos foram realizados com 0 programa STATISTICA (Version 7.0; StatSoft Inc., Tulsa, OK, USA).

\subsection{Avaliação Histológica}

Os cortes histológicos foram analisados em um microscópio óptico Axioskop 2 (Carl Zeiss), procurando-se descrever as seguintes ocorrências:

- A altura óssea ao redor dos implantes osseointegráveis, em ambos os lados;

- A interação osso-implante;

- As características do tecido ósseo ao redor dos implantes, em ambos os lados. 


\section{Resultados}





\section{RESULTADOS}

Para efeito de melhor compreensão, este capítulo foi dividido em três partes. Na primeira parte, abordaram-se os aspectos clínicos, considerando-se a porcentagem de implantes em cada grupo que permaneceu estável 120 dias após a sua instalação. Além disso, demonstraram-se as porcentagens de sucesso para os implantes instalados na maxila e na mandíbula. Numa segunda parte, relataram-se os aspectos radiográficos, considerando-se a avaliação da perda óssea em altura, nos lados esquerdo (tensão) e direito (pressão) dos implantes instalados. No último tópico, demonstraram-se os aspectos histológicos dos implantes instalados, com destaque especial à interação osso/implante.

\subsection{Resultados Clínicos}

Os resultados da avaliação clínica para estabelecer a taxa de sucesso nos vários grupos estão apresentados nas Tabelas 1, 3 e 4, e as respectivas análises estatísticas nas Tabelas 2 e 5.

Tabela 1. Grupos 1-5: Implantes estáveis 120 dias após a instalação, implantes perdidos, total de implantes instalados

\begin{tabular}{cccc}
\hline GRUPO & ESTÁVEIS & PERDIDOS & TOTAL \\
\hline Grupo 1 & $12(100 \%)$ & $0(0 \%)$ & 12 \\
\hline Grupo 2 & $6(100 \%)$ & $0(0 \%)$ & 6 \\
\hline Grupo 3 & $5(42 \%)$ & $7(58 \%)$ & 12 \\
\hline Grupo 4 & $13(65 \%)$ & $7(35 \%)$ & 20 \\
\hline Grupo 5 & $19(95 \%)$ & $1(5 \%)$ & 20 \\
\hline
\end{tabular}


Tabela 2. Teste Exato de Fisher: comparação entre os Grupos 1-5, considerando-se os implantes estáveis após 120 dias da instalação e os implantes perdidos

\begin{tabular}{cc}
\hline COMPARAÇÃO ENTRE GRUPOS & P \\
\hline Grupo 1 X Grupo 2 & 1,0000 \\
\hline Grupo 1 X Grupo 3 & $0,0046^{*}$ \\
\hline Grupo 1 X Grupo 4 & 0,0288 \\
\hline Grupo 1 X Grupo 5 & 1,0000 \\
\hline Grupo 2 X Grupo 3 & 0,0377 \\
\hline Grupo 2 X Grupo 4 & 0,1456 \\
\hline Grupo 2 X Grupo 5 & 1,0000 \\
\hline Grupo 3 X Grupo 4 & 0,2769 \\
\hline Grupo 3 X Grupo 5 & $0,0016^{*}$ \\
\hline Grupo 4 X Grupo 5 & 0,0436
\end{tabular}

* Estatisticamente significante para $\mathrm{P}<0,005$

Tabela 3. Implantes instalados na maxila Grupos 1-5: Implantes estáveis 120 dias após a instalação, implantes perdidos, total de implantes instalados na maxila

\begin{tabular}{cccc}
\hline MAXILA & ESTÁVEIS & PERDIDOS & TOTAL \\
\hline Grupo 1 & $6(100 \%)$ & $0(0 \%)$ & 6 \\
\hline Grupo 2 & $3(100 \%)$ & $0(0 \%)$ & 3 \\
\hline Grupo 3 & $1(17 \%)$ & $5(83 \%)$ & 6 \\
\hline Grupo 4 & $5(50 \%)$ & $5(50 \%)$ & 10 \\
\hline Grupo 5 & $9(90 \%)$ & $1(10 \%)$ & 10 \\
\hline
\end{tabular}


Tabela 4. Implantes instalados na mandíbula Grupos 1-5: Implantes estáveis 120 dias após a instalação, implantes perdidos, total de implantes instalados na mandíbula

\begin{tabular}{cccc}
\hline MANDÍBULA & ESTÁVEIS & PERDIDOS & TOTAL \\
\hline Grupo 1 & $6(100 \%)$ & $0(0 \%)$ & 6 \\
\hline Grupo 2 & $3(100 \%)$ & $0(0 \%)$ & 3 \\
\hline Grupo 3 & $4(67 \%)$ & $2(33 \%)$ & 6 \\
\hline Grupo 4 & $8(80 \%)$ & $2(20 \%)$ & 10 \\
\hline Grupo 5 & $10(100 \%)$ & $0(0 \%)$ & 10 \\
\hline
\end{tabular}

Tabela 5. Teste Exato de Fisher: comparação entre os implantes instalados na maxila e na mandíbula, para cada um dos grupos, considerando-se os implantes estáveis após 120 dias da instalação e os implantes perdidos

\begin{tabular}{cc}
\hline COMPARAÇÃO ENTRE GRUPOS & $\mathbf{P}$ \\
\hline Grupo 1 Maxila x Mandíbula & 1,0000 \\
\hline Grupo 2 Maxila x Mandíbula & 1,0000 \\
\hline Grupo 3 Maxila x Mandíbula & 0,2424 \\
\hline Grupo 4 Maxila x Mandíbula & 0,3498 \\
\hline Grupo 5 Maxila x Mandíbula & 1,0000 \\
\hline
\end{tabular}

*Estatisticamente significante para $\mathrm{P}<0,01$

\subsection{Resultados Radiográficos}

\subsubsection{Erro do método}

Os resultados do erro relacionados à quantificação radiográfica serão apresentados na Tabela 6. Nessa tabela, são apresentados os valores dos erros casuais (DAHLBERG, 1940) e sistemáticos (HOUSTON, 1983), da avaliação intraexaminador para a perda óssea em altura. Estes testes de erro têm a função de 
comprovar a reprodutibilidade da metodologia utilizada. Os resultados em destaque $\left(^{*}\right)$ são estatisticamente significantes para $\mathrm{P}<0,05$.

Tabela 6. Perda óssea em altura $(\mathrm{mm})$ nos lados de tensão (esquerdo) e pressão (direito): média, desvio-padrão (DP) das duas medições, teste "t" pareado (P) e erro de Dahlberg (Erro)

\begin{tabular}{lcccccc}
\hline $\begin{array}{c}\text { Perda Óssea } \\
(\mathbf{m m})\end{array}$ & \multicolumn{2}{c}{ Medição 1 } & \multicolumn{2}{c}{ Medição 2 } & \multirow{2}{*}{ P } & \multirow{2}{*}{ Erro } \\
\cline { 2 - 5 } & Média & $\mathbf{D P}$ & Média & $\mathbf{D P}$ & & \\
\hline Lado Esquerdo & 0,93 & 1,23 & 0,93 & 1,23 & 0,9434 & 0,05 \\
\hline Lado Direito & 0,79 & 0,96 & 0,80 & 0,96 & 0,4644 & 0,06 \\
\hline
\end{tabular}

A análise estatística mostrou que não houve diferenças estatisticamente significantes para a análise do erro intra-examinador, tanto do lado esquerdo como do direito.

\subsubsection{Perda óssea em altura}

Foram comparadas as medidas das perdas ósseas em milímetros 120 dias após a instalação dos implantes osseointegráveis, considerando-se os lados esquerdo (tensão) e direito (pressão). Os resultados destacados $\left({ }^{*}\right)$ são estatisticamente significantes para $\mathrm{P}<0,05$.

Tabela 7. Perda óssea em altura $(\mathrm{mm})$ no lado esquerdo (tensão) para os Grupos 15: Média e Desvio-Padrão (DP)

\begin{tabular}{ccc}
\hline $\begin{array}{c}\text { Perda Óssea }(\mathrm{mm}) \\
\text { Tensão }\end{array}$ & Média & DP \\
\hline Grupo 1 & $0,41^{\mathrm{a}}$ & 0,5763 \\
\hline Grupo 2 & $0,08^{\mathrm{a}}$ & 0,2122 \\
\hline Grupo 3 & $3,13^{\mathrm{b}}$ & 1,8928 \\
\hline Grupo 4 & $0,92^{\mathrm{a}}$ & 1,2689 \\
\hline Grupo 5 & $0,96^{\mathrm{a}}$ & 0,8665
\end{tabular}

Letras diferentes representam diferenças estatisticamente significantes 
Tabela 8. Comparação da perda óssea em altura (mm), para os Grupos 1-5, no lado esquerdo (tensão): médias e valores de $\mathrm{P}$

\begin{tabular}{cc}
\hline COMPARAÇÃO ENTRE GRUPOS & P \\
\hline Grupo 1 X Grupo 2 & 0,9677 \\
\hline Grupo 1 X Grupo 3 & $0,0001^{*}$ \\
\hline Grupo 1 X Grupo 4 & 0,7114 \\
\hline Grupo 1 X Grupo 5 & 0,5717 \\
\hline Grupo 2 X Grupo 3 & $0,0002^{*}$ \\
\hline Grupo 2 X Grupo 4 & 0,4570 \\
\hline Grupo 2 X Grupo 5 & 0,3525 \\
\hline Grupo 3 X Grupo 4 & $0,0012^{*}$ \\
\hline Grupo 3 X Grupo 5 & $0,0009^{*}$ \\
\hline Grupo 4 X Grupo 5 & 0,9999 \\
\hline
\end{tabular}

*Estatisticamente significante para $\mathrm{P}<0,05$

A análise estatística mostrou que não houve diferença na perda óssea entre os Grupos 1, 2, 4 e 5 para o lado esquerdo (tensão). No Grupo 3, a perda óssea foi maior em relação a todos os demais grupos.

Tabela 9. Perda óssea em altura (mm) no lado direito (pressão) para os Grupos 1-5: Média e Desvio-Padrão (DP)

\begin{tabular}{ccc}
\hline $\begin{array}{c}\text { Perda Óssea }(\mathbf{m m}) \\
\text { Tensão }\end{array}$ & Média & DP \\
\hline Grupo 1 & $0,26^{\mathrm{a}}$ & 0,3879 \\
\hline Grupo 2 & $0,59^{\mathrm{a}}$ & 0,8735 \\
\hline Grupo 3 & $2,43^{\mathrm{b}}$ & 1,4586 \\
\hline Grupo 4 & $0,46^{\mathrm{a}}$ & 0,5404 \\
\hline Grupo 5 & $0,98^{\mathrm{a}}$ & 0,8651 \\
\hline
\end{tabular}

Letras diferentes representam diferenças estatisticamente significantes 
Tabela 10. Comparação da perda óssea em altura (mm), para os Grupos 1-5, no lado direito (pressão): médias e valores de $\mathrm{P}$

\begin{tabular}{cc}
\hline COMPARAÇÃO ENTRE GRUPOS & P \\
\hline Grupo 1 X Grupo 2 & 0,9172 \\
\hline Grupo 1 X Grupo 3 & $0,0001^{*}$ \\
\hline Grupo 1 X Grupo 4 & 0,9661 \\
\hline Grupo 1 X Grupo 5 & 0,1063 \\
\hline Grupo 2 X Grupo 3 & $0,0030^{*}$ \\
\hline Grupo 2 X Grupo 4 & 0,9975 \\
\hline Grupo 2 X Grupo 5 & 0,8184 \\
\hline Grupo 3 X Grupo 4 & $0,0002^{*}$ \\
\hline Grupo 3 X Grupo 5 & $0,0055^{*}$ \\
\hline Grupo 4 X Grupo 5 & 0,3616
\end{tabular}

*Estatisticamente significante para $\mathrm{P}<0,05$

No lado direito (pressão), a perda óssea não mostrou diferenças estatisticamente significantes entre os Grupos 1, 2, 4 e 5. O Grupo 3 exibiu perda óssea estatisticamente significantemente maior em relação a todos os demais grupos.

Tabela 11. Comparação da perda óssea em altura $(\mathrm{mm})$, entre os lados esquerdo e direito, para os Grupos 1-5: média, desvio-padrão (DP) e valores de P

\begin{tabular}{cccccc}
\hline $\begin{array}{c}\text { Perda Óssea } \\
(\mathbf{m m})\end{array}$ & \multicolumn{2}{l}{ Lado Esquerdo } & \multicolumn{2}{l}{ Lado Direito } & \multirow{2}{*}{$\mathbf{P}$} \\
\cline { 2 - 5 } & Média & $\mathbf{D P}$ & Média & $\mathbf{D P}$ & \\
\hline Grupo 1 & 0,41 & 0,57 & 0,26 & 0,38 & 0,2283 \\
\hline Grupo 2 & 0,08 & 0,21 & 0,59 & 0,87 & 0,2296 \\
\hline Grupo 3 & 3,13 & 1,89 & 2,43 & 1,45 & 0,1144 \\
\hline Grupo 4 & 0,92 & 1,26 & 0,46 & 0,54 & 0,1251 \\
\hline Grupo 5 & 1,00 & 0,89 & 1,03 & 0,90 & 0,8776 \\
\hline
\end{tabular}

*Estatisticamente significante para $\mathrm{P}<0,05$ 
Não houve diferenças estatisticamente significantes entre o lado esquerdo e direito nos vários grupos experimentais.

\subsection{Resultados Histológicos}

\section{Grupo 1 - Implante sepultado sem carga (Figura 12)}

Os implantes estavam osseointegrados, com grande quantidade de tecido ósseo periimplantar e altura da crista óssea variando entre a primeira rosca e a plataforma do implante. Em ambos os lados, foram observadas em toda a extensão da superfície do implante, zonas de contato entre o tecido ósseo e o implante, e áreas de reabsorção associada à remodelação óssea. Pequena saucerização periimplantar na região da crista óssea alveolar ocorreu em ambos os lados.

\section{Grupo 2 - Implante sepultado em área de extração sem carga (Figura 13)}

O quadro histológico foi similar ao do Grupo 1, ou seja, os implantes estavam osseointegrados, com grande quantidade de tecido ósseo periimplantar e altura da crista óssea variando entre a primeira rosca e a plataforma do implante. Em ambos os lados, foram observadas zonas de contato entre o tecido ósseo e o implante em toda a extensão das roscas e áreas de reabsorção associada à remodelação óssea. A saucerização periimplantar na região da crista óssea alveolar foi pequena ou ausente.

\section{Grupo 3 - Implante exposto a interferências oclusais (Figura 14)}

Os implantes deste grupo exibiam falhas na osseointegração, com epitelização da sua superfície em quase toda a extensão das roscas (veja imagem panorâmica no centro da figura) e espessa camada de tecido conjuntivo separando o implante do tecido ósseo. A perda óssea foi acentuada e pequenas porções de tecido remanescentes da reabsorção foram observadas na região periimplantar. $A$ altura da crista óssea foi inferior ao terço médio do implante, e a ancoragem óssea ocorreu apenas no terço apical, na região da câmara de ossificação apical (observar a imagem central em menor aumento). 


\section{Grupo 4 - Implante submetido à carga ortodôntica imediata (Figura 15)}

Os implantes deste grupo mostravam osseointegração, com moderada quantidade de tecido ósseo periimplantar de arranjo mais compacto e altura da crista óssea variando entre a primeira e a segunda rosca, sendo mais alta no lado de tensão. As zonas de contato entre osso-implante estavam presentes principalmente nas roscas do terço cervical, o que evitou a perda em altura óssea. Em alguns casos, uma fina camada de tecido conjuntivo separando o implante do tecido ósseo periimplantar estava presente nos terços médio e/ou apical. Áreas de reabsorção e neoformação óssea indicando intensa remodelação óssea estavam presentes em ambos os lados. A saucerização periimplantar estava presente em ambos os lados.

\section{Grupo 5 - Implante em área de extração, submetido à carga ortodôntica imediata (Figura 16)}

O quadro histológico deste grupo demonstrou que havia osseointegração, com grande quantidade de tecido ósseo periimplantar de arranjo lamelar e compacto e altura da crista óssea variando entre a primeira e a segunda rosca, sendo mais alta no lado de tensão. Extensas zonas de contato entre osso e o implante estavam presentes em toda extensão das roscas, além de áreas de reabsorção óssea associada à intensa atividade de remodelação. A saucerização periimplantar estava presente na região da crista óssea alveolar, em ambos os lados. 

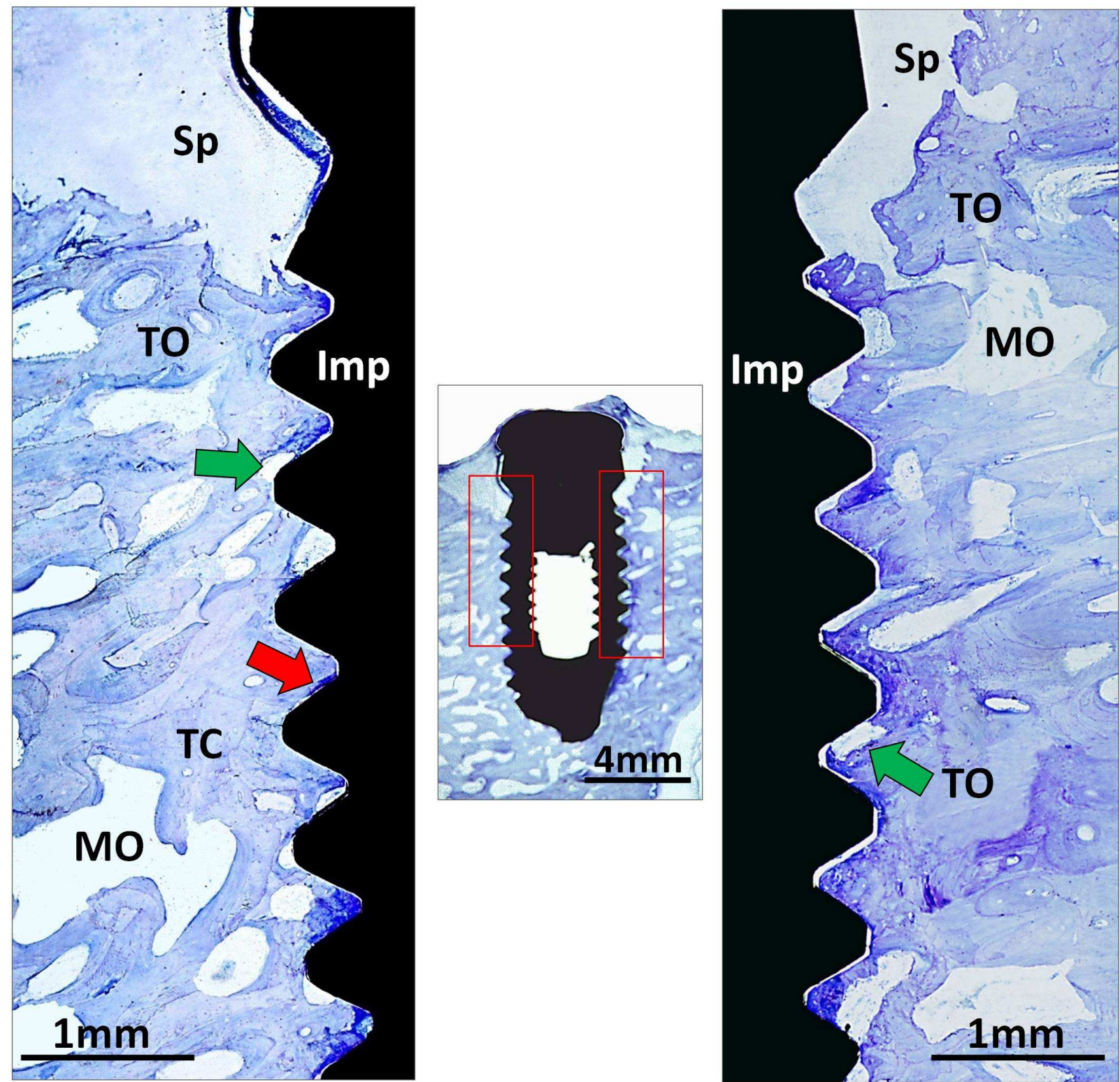

Figura 12: Fotomicrografia em secção longitudinal do implante (Imp) sepultado, 120 dias após sua instalação (Grupo 1). Observar a grande quantidade de tecido ósseo periimplantar de arranjo predominantemente trabeculado e muitos espaços medulares (MO) e canais nutritivos em ambos os lados. Em detalhe nas fotos em maior aumento, veja zonas de contato (seta vermelha) entre o tecido ósseo e a superfície do implante $(\mathrm{Imp})$ em toda a extensão do implante, além de áreas de reabsorção associada à neoformação óssea (seta verde); saucerização periimplantar (Sp) em ambos os lados. Observar na imagem panorâmica em menor aumento que no lado direito a altura da crista óssea atinge o nível do parafuso de cobertura. Azul de Toluidina. 


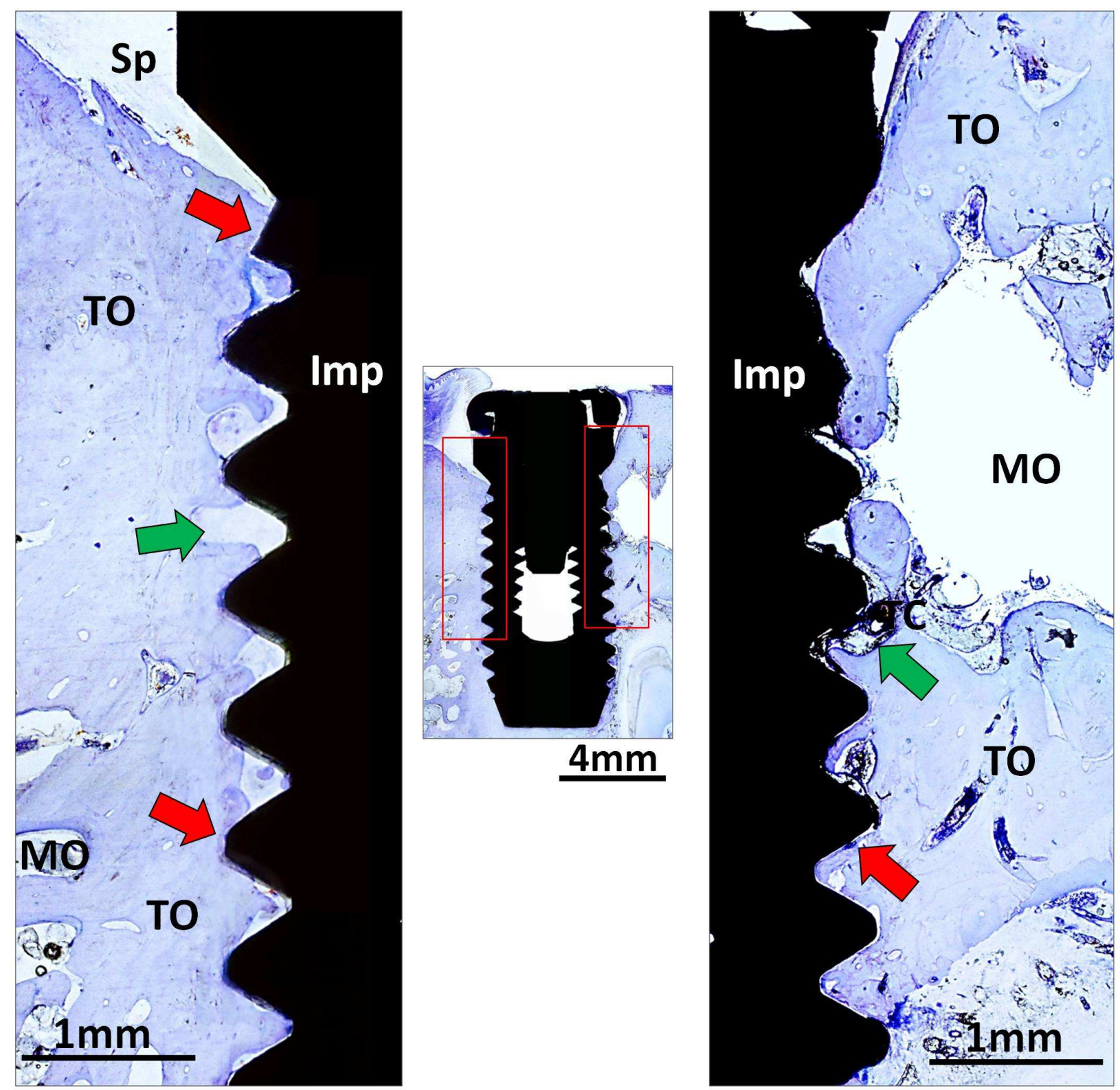

Figura 13: Fotomicrografia em secção longitudinal do implante sepultado em área de extração, 120 dias após sua instalação (Grupo 2). Observar a grande quantidade de tecido ósseo periimplantar de arranjo mais compacto e os espaços medulares (MO). Neste caso, zona de contato (seta vermelha) entre o tecido ósseo e a superfície do implante (Imp) ocorrem em toda a extensão do implante, além de áreas de reabsorção associada à neoformação óssea (seta verde). Saucerização periimplantar (Sp) pode ser observada na região da crista óssea alveolar no lado esquerdo, enquanto que no lado direito a altura da crista óssea foi mantida ao nível do parafuso de cobertura. Azul de Toluidina. 


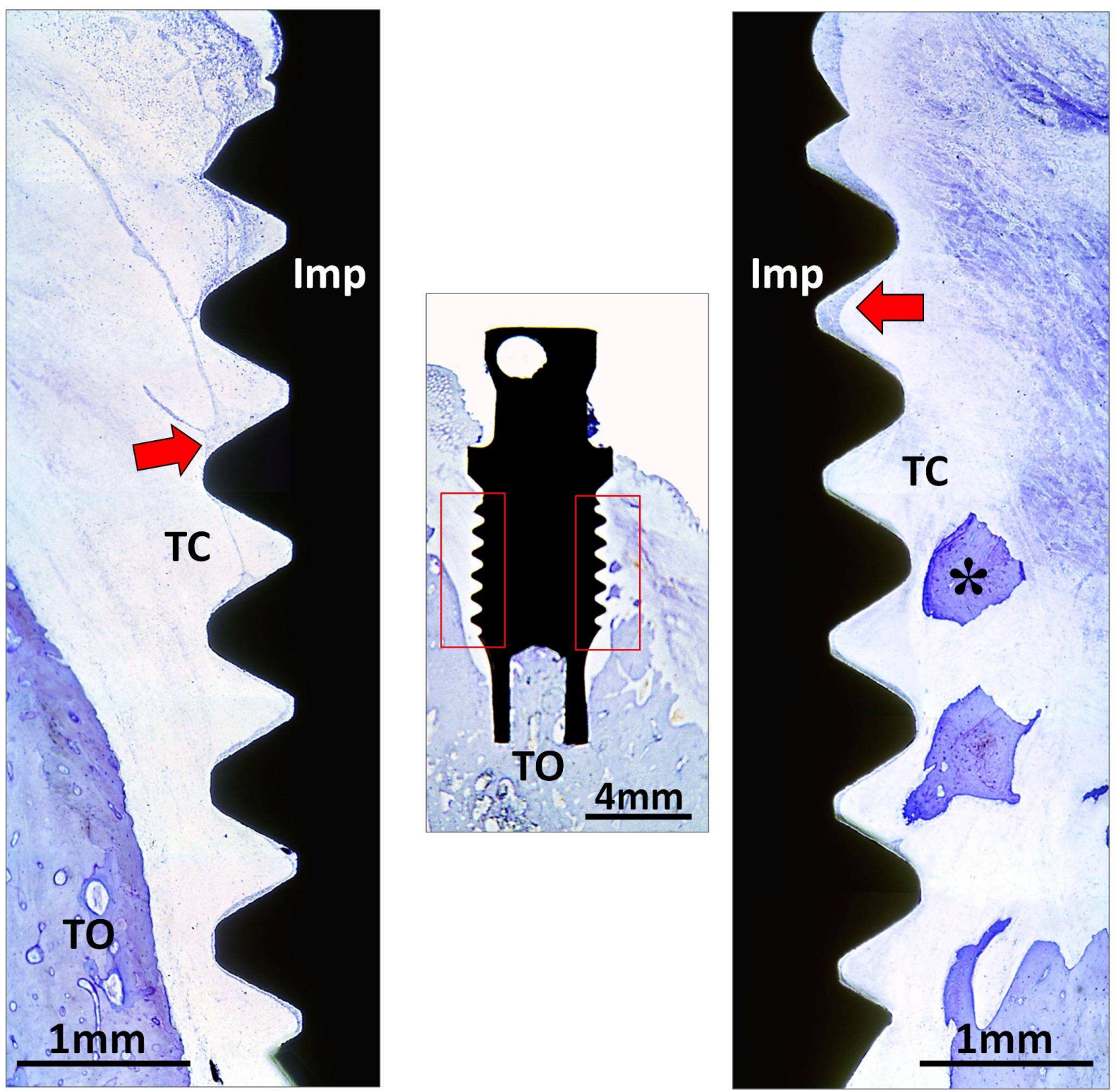

Figura 14: Fotomicrografia em secção longitudinal do implante exposto a interferências oclusais, 120 dias após sua instalação (Grupo 3). Observar a epitelização (seta vermelha) da superfície do implante $(\mathrm{Imp})$ e a presença de tecido conjuntivo (TC) envolvendo grande parte da região periimplantar e pequenas porções de tecido ósseo remanescentes da reabsorção (asterisco). Veja na imagem central panorâmica que neste caso o implante (Imp) encontra-se ancorado ao tecido ósseo (TO) apenas na região da câmara de ossificação apical. Azul de Toluidina. 


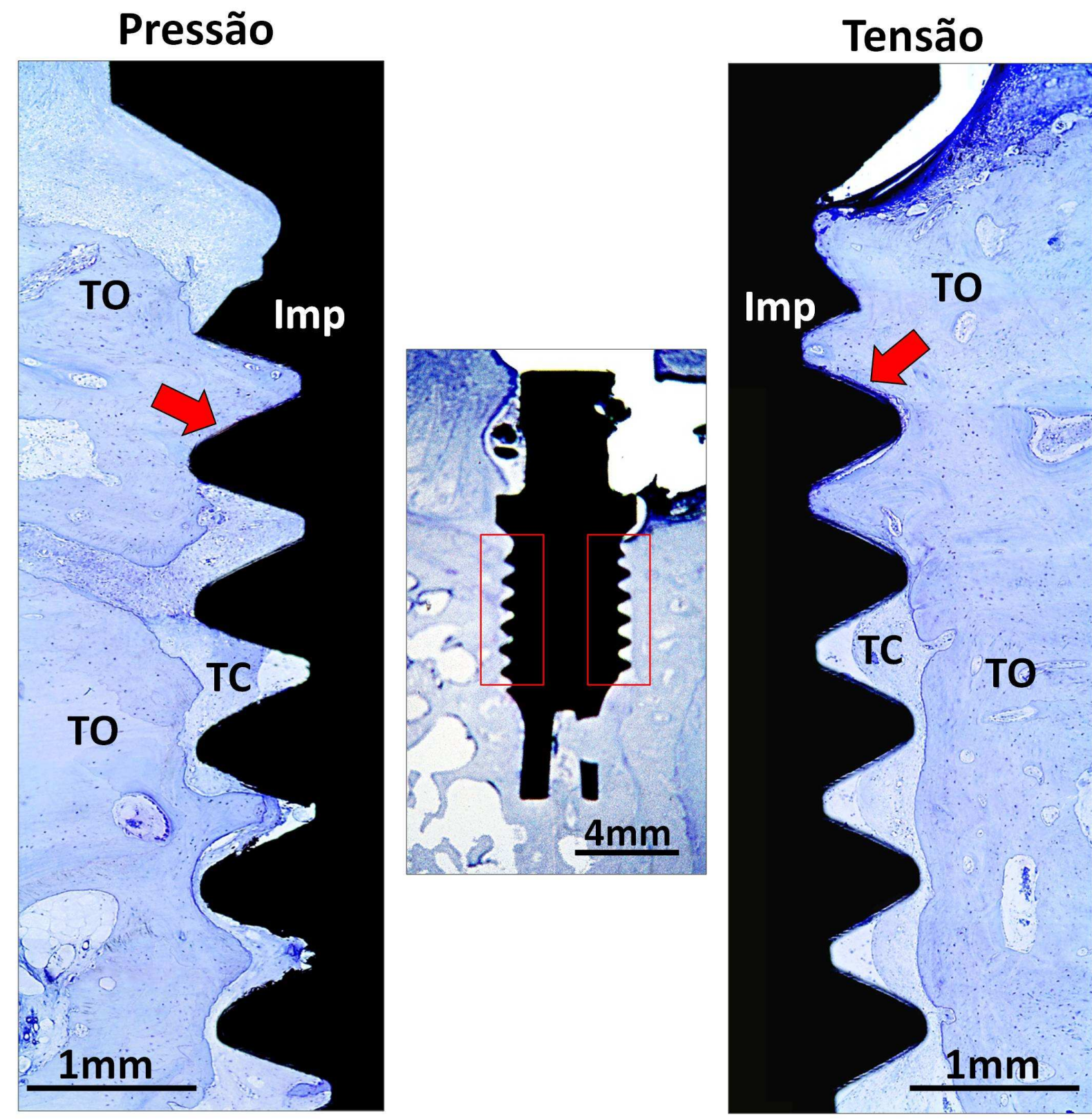

Figura 15: Fotomicrografia em secção longitudinal do implante submetido à carga ortodôntica imediata, 120 dias após sua instalação (Grupo 4). Observar a grande quantidade de tecido ósseo periimplantar de arranjo lamelar e compacto na região de tensão e pressão. Neste caso, no terço cervical o tecido ósseo (TO) mostra-se em íntimo contato (seta vermelha) com a superfície das roscas do implante, e as roscas médias e apicais, em algumas áreas, estão separadas por tecido conjuntivo (TC). Saucerização periimplantar pode ser observada na região da crista óssea alveolar em ambos os lados, sendo que a maior perda óssea ocorreu no lado de pressão. Azul de Toluidina. 


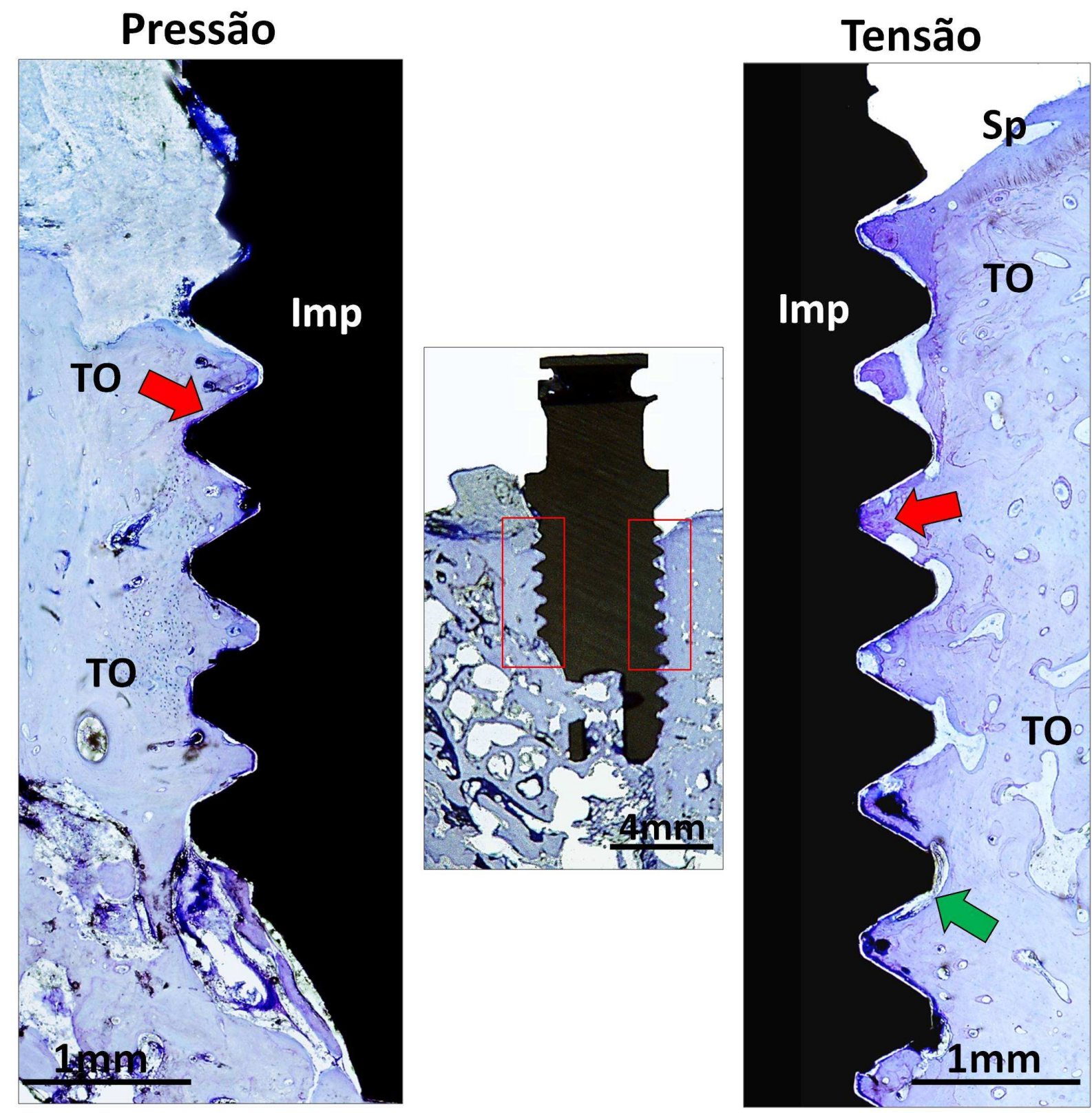

Figura 16: Fotomicrografia em secção longitudinal do implante inserido em área de extração e submetido à carga ortodôntica imediata, 120 dias após sua instalação (Grupo 5). Observar a grande quantidade de tecido ósseo periimplantar de arranjo lamelar e altamente compacto na região de pressão e tensão. Neste caso, os contatos (seta vermelha) entre o tecido ósseo e a superfície do implante (Imp) ocorrem em grande parte da extensão do implante, enquanto que a interposição de tecido conjuntivo (TC) praticamente inexiste. Saucerização periimplantar (Sp) pode ser observada na região da crista óssea alveolar em ambos os lados, sendo que a maior perda óssea ocorreu no lado de pressão. Azul de Toluidina. 



\section{Discussão}





\section{DISCUSSÃO}

Objetivando proporcionar um melhor entendimento ao leitor, na interpretação dos resultados obtidos neste trabalho, abordamos seqüencialmente os aspectos concernentes à amostra, metodologia empregada, resultados obtidos nas análises clínica, radiográfica e histológica, e finalmente, as implicações clínicas desses resultados e sugestões de futuros trabalhos.

\subsection{A amostra}

No presente trabalho, foram utilizados minipigs da colônia Minipig BR-1 (MARIANO, 2003; NAVARRO et al., 2007; NAVARRO et al., 2008; NAVARRO et al., 2008; OLTRAMARI et al., 2007b; OLTRAMARI et al., 2007c; OLTRAMARI et al., 2007), animais selecionados e desenvolvidos, no Brasil, especialmente para pesquisa. Salientamos que previamente ao desenvolvimento deste trabalho, foram realizados em nossa instituição estudos básicos com esta colônia, referentes à caracterização dentária e esquelética (OLTRAMARI et al., 2007c), e à padronização de técnicas radiográficas (NAVARRO et al., 2007), comparando as características físicas e radiográficas às de outras colônias, avaliando a possibilidade desses animais serem utilizados para pesquisa médico-odontológica.

Durante os quatro meses do experimento, os animais mostraram-se dóceis, o que facilitou sobremaneira os procedimentos de manejo, confirmando as informações de outros autores (HERRING, 1995; MARIANO, 2003; WEAVER et al., 1962). Mostraram-se resistentes, com boa recuperação pós-operatória, até mesmo nas intervenções mais invasivas, como quando ocorreram as extrações dentárias e a instalação dos implantes osseointegráveis.

Foram utilizados somente animais machos, de acordo com vários trabalhos na literatura (GIUNTA et al., 1995; NAVARRO et al., 2008; NAVARRO et al., 2008; OLTRAMARI et al., 2007b; OLTRAMARI et al., 2007; SCHABERG et al., 1985; SHEATS et al., 1991; WENFIELD et al., 1999). Esta padronização é indicada, especialmente, quando se estuda tecido ósseo, na tentativa de evitar alterações fisiológicas desse tecido ligadas a níveis variados de estrogênio nas fêmeas, 
durante o ciclo estral. Convém salientar, no entanto, que alguns pesquisadores utilizaram animais de ambos os sexos (LUNDGREN et al., 1997; YOUNG et al., 1999) ou mesmo somente fêmeas (KAWAMOTO et al., 2003; KAWAMOTO et al., 2002) em seus experimentos.

Os animais, além de padronizados quanto à colônia (Minipig BR-1) e sexo (machos), também foram padronizados quanto à idade. Utilizou-se adultos jovens (15 meses de idade), com peso médio de $35 \mathrm{Kg}$, e maturidade óssea (GEDRANGE et al., 2001).

Com relação ao tamanho da amostra utilizada nesta pesquisa, procuramos seguir trabalhos recentes desenvolvidos em animais experimentais considerados de porte intermediário a grande, como cães (ARAÚJO et al., 2001; KAWAMOTO et al., 2003; KAWAMOTO et al., 2002; SAITO et al., 2000), macacos (CUOGHI, 1996; LINDER-ARONSON et al., 1990; MELSEN, 1986; SMALLEY, W., 1995; TURLEY, P., 1980) e suínos (ÖDMAN et al., 1991; THILANDER et al., 1992; WARD et al., 1990). Nesses estudos, foi utilizado um número relativamente reduzido de animais, uma vez que nestes é possível a utilização de metodologia e/ou aparelhos usados em situações reais em humanos, o que não acontece nos animais de pequeno porte (ROBERTS et al., 1996).

Contudo, convém salientar que apesar dos animais experimentais de grande porte, em especial os suínos, apresentarem muitas semelhanças anatomofisiológicas com os humanos, os resultados experimentais não superam aqueles obtidos em pesquisas clínicas (ROBERTS et al., 1996). Apesar deste fator limitante, elas constituem-se o estágio mais avançado de testes de novos materiais e técnicas, de fundamental importância antes da sua utilização em seres humanos.

De maneira geral, concordando com outros estudos (BUCK; WEAVER, 1965; GEDRANGE et al., 2001; GIUNTA et al., 1995; HAAS, 1961; HERRING, 1995; MARIANO, 2003; MCKEAN et al., 1971; NOGUCHI et al., 1976; ÖDMAN et al., 1991; OLTRAMARI et al., 2007; THILANDER et al., 1992; URIST, 1965; WEAVER et al., 1966,1969; WEAVER et al., 1962), os suínos, em especial os minipigs, e em particular o Minipig BR-1, mostraram-se modelos experimentais adequados para estudos em Ortodontia. 


\subsection{Metodologia}

\subsubsection{Contenção dos animais}

Outro fator importante no desenvolvimento da atual pesquisa foi o método utilizado na contenção dos animais para as intervenções experimentais. Para cada espécie animal, existe um procedimento diferente de contenção que deve ser seguido para garantir a saúde do mesmo e a segurança dos profissionais que estão envolvidos no experimento. Este fato é relevante, principalmente, quando se consideram pesquisas em suínos, animais que se tornam facilmente estressados, o que dificulta os procedimentos de sedação e interfere na estabilidade do animal durante todo o tempo de trabalho (MASSONE, 1994).

A contenção recomendada para suínos é o cachimbo (MACHADO, 1967; MASSONE, 1994), composto por uma corda que envolve a maxila do animal e deve ser apertada para que ele sinta um desconforto e se mantenha imobilizado. Esta contenção não pôde ser utilizada neste trabalho porque a corda, ao ser colocada em posição, iria atingir diretamente a área de interesse para a pesquisa, onde foram instalados os implantes osseointegráveis.

Por esse motivo, desenvolveu-se um dispositivo alternativo apresentado na Figura 4 para a contenção dos animais, composto por três roldanas interligadas por corda e uma rede, para o qual o animal era conduzido e então suspenso, de maneira a impedir que ele pudesse ter algum tipo de apoio com as patas traseiras e dianteiras, e dessa forma pudesse ser imobilizado.

Este dispositivo de contenção evitou o estresse dos animais, proporcionou segurança aos pesquisadores e técnicos, facilitou os procedimentos de anestesia e, ainda, evitou danos nas áreas testadas, o que aconteceria se tivesse sido utilizado o cachimbo.

\subsubsection{Anestesia}

Para a realização de todas as intervenções, os animais receberam anestesia geral. Tomou-se o cuidado, previamente à intervenção, deles permanecerem em jejum alimentar de 12 horas e jejum hídrico de 6 horas 
(MASSONE, 1994; SWINDLE, 1994), no sentido de evitar o risco de dilatação gástrica e vômito, e da conseqüente pneumonia inalatória (SWINDLE, 1994).

É comum administrar drogas pré-anestésicas, via intramuscular, seguidas pela aplicação endovenosa de agentes anestésicos. Injeções intramusculares podem ser administradas na extensa musculatura da coxa posterior ou no músculo do pescoço (SWINDLE, 1994). Optou-se por iniciar a administração das drogas (Azaperone e Quetamina) via intramuscular, na região do pescoço; e para a manutenção da anestesia geral durante toda a intervenção, a dose inicial de quetamina foi complementada com doses via endovenosa. A veia comumente utilizada para este fim nos suínos é a veia marginal da orelha (MASSONE, 1994; SWINDLE, 1994), e esta técnica permitiu maior estabilidade do procedimento anestésico e menor consumo de medicamentos.

As técnicas clássicas de monitoração desenvolvidas para cães não são facilmente aplicáveis aos suínos, especialmente quando são utilizadas drogas combinadas. Os reflexos palpebrais e pupilares, por exemplo, não são confiáveis em suínos, particularmente se a atropina ou a quetamina estiverem incluídas no protocolo, e este foi o caso desta pesquisa. O melhor guia durante os procedimentos de sedação em suínos é o relaxamento dos músculos mandibulares (tônus mandibular) ou a ausência de qualquer reflexo da pata em resposta a um estímulo interdigital. Os indicadores mais sensíveis da superficialização da anestesia são o aumento da freqüência cardíaca e da pressão arterial (SWINDLE, 1994).

Não se realizou a ventilação artificial para os animais, porque não se dispunha dos equipamentos necessários, nem de pessoal treinado para este procedimento. Para tentar compensar esta limitação, fazia-se constante monitoração dos sinais vitais dos animais durante o procedimento cirúrgico, observando clinicamente os reflexos palpebrais e interdigitais, além de sua temperatura e freqüências respiratória e cardíaca.

Foram utilizados azaperone e quetamina (MASSONE, 1994), seguindo-se o protocolo de sedação utilizado em outras pesquisas (NAVARRO et al., 2007; NAVARRO et al., 2008; NAVARRO et al., 2008; OLTRAMARI et al., 2007b; OLTRAMARI et al., 2007c; OLTRAMARI et al., 2007). A administração do préanestésico, azaperone, pode imobilizar completamente o animal, mas sem promover analgesia. A quetamina é uma das drogas mais utilizadas nos procedimentos anestésicos em suínos, provavelmente pela alta dose de segurança $(20-33 \mathrm{mg} / \mathrm{Kg})$. 
É um efetivo agente moderador, mas não promove o relaxamento muscular suficiente, por isso é melhor utilizado em combinação com outros agentes (SWINDLE, 1994). Desta forma, a combinação azaperone e quetamina permitiu um bom tempo de trabalho e facilitou as manobras operatórias.

Durante todo o período experimental não ocorreu o óbito de nenhum animal, ou qualquer outra complicação, durante as cirurgias e controles, mostrando que os procedimentos adotados foram seguros e adequados.

\subsubsection{Método Radiográfico}

Em relação ao método radiográfico, a literatura é unânime em afirmar que os estudos realizados com base na interpretação de imagens radiográficas devem possuir aparelho, técnica e processamento radiográfico padronizados (BENDER, 1982; CORDEIRO et al., 1995; EISNER, 1990,1998; JENSEN; TUREK, 1978; PITTFORD, 1984; WALTON, 1973; ZONTINE, 1974).

Para facilitar a realização de exames radiográficos padronizados podem ser confeccionados posicionadores que ofereçam um constante relacionamento dente/filme/raios $\mathrm{X}$ ideal e contribuam para a comparação da imagem radiográfica em diversos períodos no pré e pós-operatório (BENDER, 1982; CORDEIRO et al., 1995; JENSEN; TUREK, 1978; WALTON, 1973).

A importância de utilizar dispositivos de padronização radiográfica em humanos foi relatada por diversos autores (BENDER, 1982; JENSEN; TUREK, 1978; WALTON, 1973), tanto para o diagnóstico de lesões, como para as diferentes práticas clínicas que exijam controle radiográfico em vários períodos de tratamento.

Além da padronização de técnicas radiográficas em humanos, também as tomadas radiográficas em animais devem seguir protocolos estabelecidos, considerando as diferenças anatômicas de cada espécie (CORDEIRO et al., 1995; EISNER, 1990,1998; PITTFORD, 1984; ZONTINE, 1974). Destaque maior deve ser dado à padronização de imagens obtidas de animais quando estas forem utilizadas com finalidade científica (CORDEIRO et al., 1995).

Assim, este estudo utilizou duas técnicas e posicionadores radiográficos desenvolvidos por NAVARRO et al. (2007) para a obtenção de radiografias padronizadas intrabucais. As técnicas oferecem o relacionamento dente/filme/raios $\mathrm{X}$ 
ideal e constante, o que possibilitou comparar as imagens radiográficas obtidas entre os diversos grupos da pesquisa. Além disso, obtiveram-se os exames radiográficos utilizando 0 mesmo aparelho de raios $X$ calibrado e os filmes radiográficos foram revelados manualmente pelo método tempo-temperatura.

É importante destacar que há sempre certo grau de distorção das imagens, principalmente na técnica para avaliação da região posterior na maxila, em função da anatomia dos maxilares (NAVARRO et al., 2007). Por isso, é fundamental a utilização de posicionador para esta técnica, para que o grau de distorção das imagens seja constante e possam ser comparados os exames radiográficos realizados em diferentes fases de uma pesquisa.

Para a análise radiográfica, compararam-se as medidas obtidas nos exames radiográficos contendo os 55 implantes osseointegráveis que permaneceram estáveis após 120 dias da sua instalação. Assim, foram realizadas, para cada exame radiográfico, mensurações no lado esquerdo (tensão) e direito (pressão). Como a amostra total contou 55 radiografias, ao final foram realizadas 220 medidas.

Para que os resultados desse trabalho fossem confiáveis, procurou-se minimizar o erro do método de mensuração empregado. Calculou-se a precisão do método pelos erros intra-examinador, casual e sistemático.

Para avaliar os erros de metodologia, HOUSTON (1983) recomendou que as medições fossem realizadas duas vezes. Neste estudo, seguimos este protocolo e todas as mensurações foram refeitas pelo mesmo examinador (PVPO), após 30 dias. A maior fonte de erros casuais, segundo HOUSTON (1983) acontece pela dificuldade de identificação de um ponto em particular ou pela imprecisão na definição de certos pontos. Os erros casuais nesse trabalho foram extremamente reduzidos (Tabela 6). O maior significado dos erros casuais refere-se ao seu poder de aumentar o desvio-padrão das médias obtidas. Como os erros casuais para as variáveis em estudo foram mínimos, conclui-se que os desvios-padrão encontrados para elas sejam realmente o reflexo da variabilidade dos grupos.

$\mathrm{Na}$ avaliação do erro sistemático, não houve diferença estatisticamente significante para nenhuma avaliação realizada (Tabela 6). Os erros sistemáticos se manifestam quando um parâmetro é persistentemente sub ou superestimado, podendo ocorrer quando um pesquisador modifica sua técnica de mensuração, após certo tempo, ou então quando ele tende subconscientemente a direcionar os 
resultados de acordo com suas expectativas em relação às conclusões do estudo (HOUSTON, 1983).

A ausência de erros sistemáticos e os valores reduzidos para o erro casual deram condições para continuar esta pesquisa, transmitindo a confiabilidade das mensurações e do programa selecionado para a execução das mesmas.

Ainda, é importante relatar que este estudo foi cego, uma vez que os arquivos contendo o número de cada animal foram renomeados por uma pessoa alheia à pesquisa, para evitar tendenciosidade do examinador para qualquer um dos grupos. Estes cuidados conferem confiabilidade à metodologia executada.

\subsubsection{Método Histológico}

Para a análise histológica, as porções da maxila e mandíbula, onde haviam sido instalados os implantes osseointegráveis, foram processadas para obtenção de cortes em micrótomo de tecido duro, sem a necessidade de desmineralização do material, seguindo o protocolo do laboratório da Disciplina de Histologia da Faculdade de Odontologia de Bauru-USP.

Os cortes assim obtidos preservaram todas as estruturas mineralizadas e o próprio implante, permitindo, desse modo, a avaliação de todas as inter-relações osso-implante, como a perda óssea em altura, a interface osso-implante e as características do tecido ósseo nos lados de tensão e pressão dos implantes osseointegráveis.

É oportuno destacar a importância desse tipo de análise histológica (MELLONIG, 2000; WEHRBEIN et al., 1995) numa pesquisa que avalia perda óssea ao redor de implantes osseointegráveis, pois ela vem a complementar o que é sugerido por meio de avaliações clínicas e radiográficas, e nos dá a certeza sobre os resultados obtidos. Além disso, constitui-se no método mais utilizado em estudos com animais (ANDERSON; MILLER, 1984; JAHANGIRI et al., 2005; NKENKE et al., 2005a; NKENKE et al., 2005b; NKENKE et al., 2003; RIMONDINI et al., 2005; SCHIERANO et al., 2005; SENNERBY et al., 1993; THILANDER et al., 1992; WEHRBEIN; DIEDRICH, 1993). 


\subsection{Resultados}

O presente estudo demonstrou clínica, radiográfica e histologicamente que houve diferenças em relação à perda óssea em altura ao redor dos implantes osseointegráveis mantidos sem carga durante período de reparo de 120 dias (Grupos 1 e 2), submetidos a interferências oclusais (Grupo 3) e submetidos à carga ortodôntica imediata (Grupos 4 e 5).

\subsubsection{Resultados Clínicos}

Os resultados obtidos a partir da análise clínica são relevantes para demonstrar um panorama geral sobre o estudo. Considerando os implantes sepultados (Grupos 1 e 2) e os implantes que receberam carga ortodôntica imediata (Grupos 4 e 5), não houve diferença estatisticamente significante entre os grupos, isto é, estabelecer carga ortodôntica imediata sobre implantes não provocou menor taxa de sucesso (Tabela 1).

Difere deste padrão apenas o grupo dos implantes que ficaram expostos a interferências oclusais logo após a sua instalação (Grupo 3), o qual apresentou taxa de sucesso estatisticamente inferior aos Grupos 1 e 5 (Grupos 1x3, P=0,0046; Grupos 3x5, P=0,0016) (Tabela 2). Apesar das comparações do Grupo 3 com os Grupos 2 e 4 não apresentarem resultados estatisticamente significantes, há que se destacar que a porcentagem de insucesso para o Grupo 3, foi destacadamente mais acentuada.

Uma interferência oclusal é definida como uma relação de contato oclusal, que interfere de alguma forma com a função ou parafunção. Do ponto de vista clínico, a presença de interferências oclusais define os chamados traumas oclusais (CONTI, 1998). Quando um dente natural é submetido a um trauma oclusal, os sinais e sintomas podem ser reversíveis após a remoção deste trauma. Com o implante osseointegrável isto não ocorre. Raramente uma prótese implantosuportada mostra sinais diferentes dos da fratura por fadiga (MISCH; BIDEZ, 2000; TAYLOR, 1991). A ausência de interface de tecido mole entre o osso e o implante resulta em uma concentração de forças na união implante/osso. Se a carga inicial de 
um contato prematuro é aplicada igualmente sobre um implante e um dente natural, o implante sustenta uma proporção maior de carga que não é dissipada às estruturas adjacentes como acontece nos dentes. Ainda, não existem evidências clínicas e radiográficas de que um implante está sendo submetido à tensão, a não ser uma perda óssea na região da crista marginal, que também pode ser diagnosticada como uma periimplantite (MISCH; BIDEZ, 2000).

Uma vez desfeita a osseointegração, ela não se restabelece, mesmo que seja eliminada a interferência oclusal responsável pela sobrecarga (ISIDOR, 1996). Ao comparar a condição de um dente natural submetido à carga oclusal com uma prótese implanto-suportada nas mesmas condições de carga, a força oclusal é neutralizada nos dentes naturais pela presença do periodonto de sustentação, enquanto nas próteses implanto-suportadas a força não consegue ser totalmente neutralizada. A mobilidade é variável e presente nos dentes naturais, ao passo que nas próteses implanto-suportadas ela é praticamente ausente. Facetas de desgaste, fraturas das restaurações, perda da dimensão vertical de oclusão são evidências clínicas de desgaste dentário; já nas próteses implanto-suportadas este desgaste é mínimo e geralmente ocorrem tensão e fratura dos componentes. O ligamento periodontal exerce um efeito amortecedor nos dentes naturais e permite certa intrusão e movimentos laterais, já a prótese implanto-suportada não possui esta maleabilidade, ficando a tensão acumulada na crista do rebordo (MISCH; BIDEZ, 2000).

Os implantes do Grupo 3, por serem de corpo único, permaneciam após a instalação com os intermediários expostos à cavidade bucal e sujeitos às interferências de alguns dentes. Os implantes instalados na mesial do canino superior e inferior, estavam sujeitos, quando da realização de movimentos excursivos da mandíbula, a interferências pelos caninos antagonistas. A verificação destes resultados, no momento da coleta destes grupos, instigou a investigação da causa desta perda acentuada de implantes. Ao suspeitar-se da interferência dos dentes antagonistas, testou-se a oclusão dos animais (guias anterior e lateral) e decidiu-se realizar desgastes oclusais ao término da instalação dos implantes dos Grupos 4 e 5, com o objetivo de eliminar qualquer interferência oclusal sobre os implantes destes grupos, além de isolar a variável "carga ortodôntica". 
A alta porcentagem de sucesso para os implantes dos Grupos 1, 2, 4 e 5 demonstra que a interferência oclusal dos dentes antagonistas exerceu um papel extremamente negativo nos implantes do Grupo 3, o que provocou a perda de quase $60 \%$ da amostra (Tabela 1 ).

Clinicamente, estes resultados são relevantes, pois reforçam a importância de se eliminar todas as interferências oclusais antes de finalizar a reabilitação protética de um paciente. Considerando-se a reabilitação com implantes osseointegráveis, especial atenção deve ser dada quando se propõe a utilização de carga imediata, sob o risco de perder o implante caso não seja dada a devida importância aos fatores oclusais, como ocorreu no Grupo 3 desta pesquisa. Para isso, é imprescindível conferir os fatores oclusais, com vistas às seguintes características: contatos dentários posteriores bilaterais, dimensão vertical de oclusão adequada, guias lateral e anterior sem a participação dos dentes posteriores(GARG, 2007). Estas características da oclusão ideal também são almejadas ao término do tratamento ortodôntico convencional (OLTRAMARI et al., 2007a).

Outro resultado obtido na avaliação clínica refere-se às porcentagens de sucesso para implantes instalados na maxila e na mandíbula. Estatisticamente, não houve diferença entre os grupos para esta variável (Tabela 5). Porém, é relevante discutir que houve uma considerável diferença clínica. No Grupo 3, por exemplo, $83 \%$ dos implantes instalados na maxila foram perdidos, contra $33 \%$ dos implantes instalados na mandíbula. Relata-se em importantes trabalhos da literatura (ADELL et al., 1990; ADELL et al., 1981; PIKNER et al., 2008) que os implantes instalados na maxila apresentam menor taxa de sucesso em comparação àqueles instalados na mandíbula. O tamanho reduzido da amostra deste estudo pode ter contribuído para que estas diferenças não fossem estatisticamente comprovadas, mas elas devem ser consideradas na prática clínica.

Ainda, é importante discutir os resultados demonstrados pelos implantes instalados em áreas de extração. Após dez anos de experiência com os primeiros pacientes tratados com implantes osseointegrados, Branemark et al. (1977) preconizaram que pacientes que perderam seus dentes em decorrência de ação da doença periodontal deveriam aguardar a cicatrização óssea por 12 meses antes da 
instalação dos implantes. Barzilay et al. (1991) preconizaram um período de 4 a 6 meses de cicatrização após a extração para que os implantes fossem instalados.

Contudo, vários trabalhos (BLOCK; KENT, 1991; KRUMP; BARNETT, 1991; NOVAES; NOVAES JR, 1995; POLIZZI, 2000) foram realizados na tentativa de mostrar que a instalação de implantes imediatamente após a extração de dentes é perfeitamente possível e com resultados semelhantes a implantes instalados em regiões sem infecção.

Polizzi et al. (2000) publicaram os resultados de um estudo multicentro, no qual 264 implantes instalados em alvéolos pós-extração e em alvéolos cicatrizados foram acompanhados durante 5 anos. Os índices de sucesso foram semelhantes para os dois grupos (92,4\% e 94,7\%, respectivamente). Quanto aos insucessos, a análise dos casos sugere uma ligação com a presença de doença periodontal.

O presente trabalho, concordando com a literatura citada (BLOCK; KENT, 1991; KRUMP; BARNETT, 1991; NOVAES; NOVAES JR, 1995; POLIZZI, 2000), apresentou alta taxa de sucesso para os implantes instalados em áreas pósextração, Grupos 2 e 5 (Tabela 1). Desta forma, este protocolo parece não inviabilizar a utilização destes implantes para ancoragem ortodôntica e posterior reabilitação protética.

\subsubsection{Resultados da avaliação radiográfica quantitativa da perda óssea}

Resultados radiográficos a respeito do comportamento ósseo ao redor dos implantes osseointegráveis constituem um dos mais importantes parâmetros utilizados nas pesquisas clínicas prospectivas (PIKNER et al., 2008). Alguns critérios para determinar a longevidade dos implantes osseointegráveis têm sido propostos na literatura (ALBREKTSSON; ZARB, 1993; ALBREKTSSON et al., 1986). Estes trabalhos relatam que para ter sucesso um implante deve apresentar menos de $1,5 \mathrm{~mm}$ de perda óssea durante o primeiro ano e, após este período, menos de 
0,2mm de tecido ósseo na região da crista óssea marginal pode ser perdido a cada ano subseqüente.

Neste trabalho, 4 meses após a instalação dos implantes osseointegráveis, não houve perda óssea estatisticamente significante no lado esquerdo (tensão) para os Grupos 1, 2, 4 e 5 (Tabelas 7 e 8). Apenas o Grupo 3 demonstrou uma perda óssea em altura significantemente maior em relação a todos os demais grupos da pesquisa ( $G$ 3: Média=3,13mm; $G 3 \times 1, P=0,0001$; $G 3 \times 2$, $P=0,0002 ; G 3 \times 4, P=0,0012 ; G 3 \times 5, P=0,0009$ ).

Da mesma forma, quando considerada a perda óssea em altura para o lado direito (pressão) (Tabelas 9 e 10), não houve perda significante para os Grupos 1, 2, 4 e 5. Apenas o Grupo 3 demonstrou uma perda óssea em altura significantemente maior em relação a todos os demais grupos da pesquisa (G 3 : Média=2,43mm; G 3x1, P=0,0001; G 3x2, P=0,0030; G 3x4, P=0,0002; G 3x5, $P=0,0055)$.

Estes resultados, em concordância com os resultados clínicos obtidos nesta pesquisa e descritos previamente, demonstraram a importância da eliminação das interferências oclusais para a obtenção de sucesso quando da utilização de implantes osseointegráveis. Nesse sentido, para favorecer a longevidade do implante é importante evitar a sobrecarga oclusal (PETRIE; WILLIAMS, 2007). Pesquisas têm sugerido que o estresse acentuado na região da crista óssea, causado por carga inadequada nos implantes, pode estimular a perda e a reabsorção óssea (HOSHAW et al., 1994; STANFORD; BRAND, 1999).

Por outro lado, os Grupos 1, 2, 4 e 5 não apresentaram perdas ósseas em altura significantes, para os lados de tensão e pressão (Tabelas 7-10). Estes grupos apresentaram apenas valores médios para perda óssea em altura muito reduzidos (menores que $1 \mathrm{~mm}$ ) na região da crista óssea marginal (lado esquerdo - G1: 0,41mm; G2: 0,08mm; G4: 0,92mm; G5: 0,96mm; lado direito - G1: 0,26mm; G2: 0,59mm; G4: 0,46mm; G5: 0,98mm). Este processo de perda óssea na região da crista marginal, detectado radiograficamente, é conhecido como saucerização periimplantar (HOSHAW et al., 1994; PIKNER et al., 2008; STANFORD; BRAND, 1999), e é esperado e aceitável quando em pequena quantidade. 
Muitos fatores são destacados na literatura como responsáveis pela perda óssea na região da crista óssea marginal, assim como a carga oclusal excessiva (HOSHAW et al., 1994; PETRIE; WILLIAMS, 2007; STANFORD; BRAND, 1999), a qualidade e o volume ósseo inadequados (HERRMANN et al., 2005), o local de inserção dos implantes (maxila ou mandíbula) (PIKNER et al., 2008), a idade do paciente (PIKNER et al., 2008), entre outros fatores. Contudo, apesar destes fatores revelarem em algumas pesquisas resultados significantes, eles são pouco relevantes quando considerados do ponto de vista clínico (PIKNER et al., 2008).

Desta forma, os resultados radiográficos obtidos nesta pesquisa indicam que os Grupos 1, 2, 4 e 5 demonstraram perda óssea aceitável na região da crista óssea periimplantar, a qual não comprometeu a estabilidade clínica dos implantes. Ainda, eles sugerem que a utilização de carga imediata para ancoragem em Ortodontia não prejudica a posterior utilização desses implantes para a reabilitação protética, objetivo primário da indicação deste protocolo.

\subsubsection{Resultados Histológicos}

Os princípios fisiológicos coordenam todos os aspectos da reparação óssea ao redor do implante e da sua função em longo prazo. O conhecimento da fisiologia, do metabolismo e da biomecânica fundamental do osso é essencial para os clínicos que atuam na área de Implantodontia e especialidades envolvidas no tratamento multidisciplinar de pacientes desdentados, assim como a Ortodontia.

A histocompatibilidade dos implantes osseointegráveis é avaliada pela presença de reações inflamatórias agudas ou crônicas, assim como por acúmulo de fibras colágenas periimplantares (encapsulação). O exame histopatológico em estudos com animais é o método mais freqüentemente encontrado na literatura para a avaliação de tecidos periimplantares (ANDERSON; MILLER, 1984; JAHANGIRI et al., 2005; NKENKE et al., 2005a; NKENKE et al., 2005b; NKENKE et al., 2003; RIMONDINI et al., 2005; SCHIERANO et al., 2005; SENNERBY et al., 1993; THILANDER et al., 1992; WEHRBEIN; DIEDRICH, 1993). 
Antes da instalação dos implantes, a maioria das áreas edêntulas são atróficas, como resultado da perda óssea patológica e ausência de função. Desta forma, os implantes osseointegráveis permitem a recuperação da função nestas áreas.

Após a instalação dos implantes osseointegráveis, o processo normal de reparação da ferida, que ocorre após o trauma cirúrgico, impossibilita a avaliação da reação tecidual aos implantes. Deve-se esperar, ao menos, uma semana após a implantação, isto porque as reações teciduais reparadoras após o trauma cirúrgico predominam durante os primeiros cinco a sete dias. A reparação pode ocorrer por aposição óssea ou pela encapsulação por tecido conjuntivo. Quando ocorre o contato direto do osso com o implante denomina-se osseointegração (ADELL et al., 1985).

Durante o preparo do leito do implante, os vasos sangüíneos periostais, intracorticais e endosteais são lesados. Como resultado, há um acúmulo sangüíneo no espaço periimplantar, com uma frouxa adesão de fibrina tanto na superfície do osso como na do implante. Esse hematoma será remodelado por um tecido de granulação com novos capilares e tecido conjuntivo fibroso rico em colágeno em sete a quatorze dias. A formação de novo osso pode ocorrer diretamente ao redor do implante, dependendo do grau de sua estabilidade (SENNERBY et al., 1991).

Assim, se houver boa estabilidade pós-operatória do implante em osso cortical, o processo de reparo envolve seis estágios fisiológicos: (1) formação do calo ósseo (15 dias) - estágio inicial, resposta mediada por citocinas para estabilização do implante; (2) maturação do calo ósseo (15-45 dias); (3) fenômeno de aceleração regional ( $R A P$ ) (45 dias-12 meses) - remodelação da área necrótica e do osso de suporte; (4) osseointegração - finalização do processo de RAP, aumentando o contato ósseo direto com o implante; (5) maturação do osso de suporte - mineralização secundária do novo tecido ósseo; e (6) manutenção a longo prazo da osseointegração - contínua remineralização na interface osso-implante.

A cobertura completa da superfície do implante por tecido ósseo não ocorre em todos os casos, apenas em $56-85 \%$. As áreas de superfície do implante não recobertas por tecido ósseo apresentarão células adiposas sem uma camada fibrosa intermediária (SENNERBY et al., 1991). 
O potencial de reparo de um implante é determinado por três fatores: (1) qualidade de tecido ósseo na área da inserção do implante; (2) estabilidade pósoperatória do implante; e (3) grau de integração na interface osso-implante.

A falta de estabilidade durante a fase de reparação é a principal razão para o acúmulo de tecido conjuntivo ao redor dos implantes nos leitos ósseos. $O$ movimento excessivo do implante inibe o crescimento de capilares do leito ósseo e também afeta a diferenciação das células periimplantares em fibroblastos ou osteoblastos. O tecido ósseo se desenvolve apenas sobre fundamentos sólidos. A estabilidade influencia a diferenciação e, por conseguinte, a formação óssea. Os experimentos têm demonstrado uma correlação positiva entre o grau de mobilidade inicial do implante e o desenvolvimento de tecido conjuntivo no espaço periimplantar (ROBERTS et al., 1986; ROBERTS et al., 1984).

Com relação à instalação de carga sobre os implantes, o protocolo padrão é aguardar quatro meses para os implantes instalados na mandíbula e seis meses para os implantes instalados na maxila (ADELL et al., 1981). Porém, quando existe a presença de características ótimas, como estabilidade e qualidade de tecido ósseo, há que se considerar a possibilidade de reduzir este período de espera ou, até mesmo, eliminá-lo (carga imediata).

A carga imediata é ainda mais favorável quando se trata da utilização de implantes inicialmente para ancoragem ortodôntica, que estejam fora de oclusão, isto porque a força ortodôntica provocaria um aumento muito suave no estresse da interface osso-implante (CHEN et al., 1995)

Neste trabalho, as características dos cortes histológicos dos diferentes grupos foram compatíveis com os resultados clínicos e radiográficos obtidos e descritos previamente.

Os implantes dos Grupos 1 e 2, os quais seguiram o protocolo considerado padrão na literatura (ADELL et al., 1981), apresentaram uma reparação por meio de aposição óssea, sem a presença de encapsulação por tecido conjuntivo. Percebeu-se a presença da interação osso implante em toda extensão do parafuso. A altura óssea nos lados esquerdo (tensão) e direito (pressão) foi mantida em quase todos os cortes avaliados, e nos casos em que havia perda óssea, ela era limitada à 
região da crista óssea, caracterizando a saucerização periimplantar (HOSHAW et al., 1994; PIKNER et al., 2008).

O Grupo 3 apresentou encapsulação por tecido conjuntivo, o que comprometeria os implantes deste grupos a serem utilizados posteriormente para reabilitação protética. A excessiva carga sobre os parafusos, causada pela presença de interferências oclusais, foi provavelmente o fator causador da quase completa ausência de tecido ósseo na interface dente-osso.

Os Grupos 4 e 5 apresentaram características semelhantes aos implantes sepultados (Grupos 1 e 2), com processo de cicatrização por aposição óssea, sem a presença de encapsulação por tecido conjuntivo. Percebeu-se a presença da interação osso implante em quase toda extensão do parafuso, porém este tecido ósseo, ainda imaturo, apresentou características de um tecido em intensa atividade, com áreas de reabsorção e áreas de neoformação. Este aspecto de remodelação constante na interface implante-osso foi, provavelmente, devido à incidência de carga ortodôntica constante de intensa magnitude, promovida pelas molas de Níquel-Titânio ativadas. Estes resultados indicam que é possível utilizar os implantes destes grupos para posterior reabilitação protética, uma vez que não houve comprometimento do seu processo reparador, e a alta relação osso-implante irá conferir estabilidade em longo prazo.

Estes resultados concordam com trabalhos prévios da literatura que sugeriram que a carga ortodôntica não causa danos para a reparação óssea periimplantar e desta forma não inviabiliza a utilização dos parafusos para reabilitação protética (CHEN et al., 1995; ROBERTS et al., 1989; ROBERTS et al., 1986).

Com relação aos grupos 2 e 5, que tiveram os implantes instalados logo após a extração de elementos dentários, não houve diferença com relação aos aspectos histológicos e a qualidade do tecido ósseo encontrado. Isto indica que se houver boa estabilidade pós-cirúrgica, não haverá prejuízo para a cicatrização e manutenção de implantes em áreas de extração, ainda que sob carga imediata. 


\subsection{Considerações Clínicas}

A literatura é unânime em afirmar que a utilização de implantes osseointegráveis como ancoragem ortodôntica é uma opção de tratamento eficaz e com resultados seguros (CREEKMORE; EKLUND, 1983; GRAY et al., 1983; HIGUCHI; SLACK, 1991; LINDER-ARONSON et al., 1990; LINKOW, 1970; ÖDMAN et al., 1988; ROBERTS et al., 1984; SENNERBY et al., 1993; SHERMAN, 1978; SHUFFORD; KRAUT, 1989; SMALLEY et al., 1988; SMITH, 1979; THILANDER et al., 1992; TURLEY, 1980; TURLEY et al., 1988; VAN ROEKEL, 1989). Além disso, os implantes mostram-se versáteis aos diversos planejamentos, ortodônticos ou ortopédicos, pois têm demonstrado estabilidade mesmo quando submetidos a cargas intensas (GOTFREDSEN et al., 2001; MELSEN; COSTA, 2000; MELSEN; LANG, 2001; WEHRBEIN et al., 1998).

Os implantes osseointegráveis possibilitam uma melhor condição de trabalho para o ortodontista nos casos de pacientes adultos com impossibilidade do uso de ancoragem intrabucal, em que há a necessidade de se movimentar os dentes remanescentes. A região posterior, geralmente, é a mais atingida, o que dificulta, ou mesmo, impossibilita a movimentação dos dentes restantes. Com a perda dos dentes posteriores, em especial os inferiores, a força mastigatória concentra-se nos dentes anteriores, o que ocasiona, freqüentemente, um colapso oclusal com o aparecimento de diastemas pela vestibularização dos dentes anteriores. Em conseqüência, há o aparecimento de uma mordida de topo ou cruzada na região anterior (FRANCISCHONE et al., 2004).

Apesar de hoje os ortodontistas disporem de dispositivos temporários de tamanho reduzido para ancoragem ortodôntica, como por exemplo as miniplacas (UMEMORI, 1999) e os mini-implantes (BAE et al., 2002; BÜCHTER et al., 2005; OHMAE et al., 2001; PARK et al., 2004a; PARK et al., 2004b; PARK et al., 2005; PARK et al., 2003), não se justifica submeter pacientes com perdas dentárias múltiplas, que necessitem de reabilitação protética pós-ortodontia, a três procedimentos cirúrgicos, isto é, primeiramente a instalação do dispositivo temporário para ancoragem, a remoção do dispositivo temporário e, em seguida, a instalação do implante convencional como pilar protético. Um único procedimento 
cirúrgico, com planejamento cuidadoso, aumenta o conforto para o paciente e diminui os custos e o tempo total de tratamento.

Nesse sentido, para que seja possível a utilização de um implante osseointegrável para ancoragem ortodôntica e posterior reabilitação protética, tornase imprescindível a colocação do implante na posição ideal. Para isso, é necessária e obrigatória a execução do planejamento reverso (FRANCISCHONE; VASCONCELOS, 1998). O planejamento reverso significa planejamento multidisciplinar - ortodôntico, protético, estético - realizado em modelos de estudo previamente ao procedimento cirúrgico para a instalação do implante osseointegrável. A partir deste protocolo, estuda-se o espaço protético, a necessidade de movimentação dentária, a forma, posição e contorno da futura coroa protética, bem como o posicionamento ideal do implante. Dependendo do grau de complexidade do caso, a obtenção de modelos de estudo montados no articulador semi-ajustável deverá ser realizada para possibilitar um estudo mais detalhado das relações intermaxilares (FRANCISCHONE et al., 2004).

Outro aspecto clínico relevante para o tratamento de pacientes desdentados parciais em conjunto com a Ortodontia e a Implantodontia é o tempo de remodelação óssea necessário após a colocação do implante para o início da ativação ortodôntica.

A reabilitação com implantes osseointegrados ad modum Branemark apresenta alto índice de sucesso. Desde 1969 (BRANEMARK et al., 1969b), quando o primeiro trabalho foi publicado, e após a divulgação dos resultados de 10 anos de acompanhamento clínico (BRANEMARK et al., 1977), houve uma evolução marcante na Implantodontia. O sistema Branemark foi originalmente desenvolvido para ser realizado em dois tempos cirúrgicos, ou seja, o implante é deixado submerso para que ocorra a osseointegração antes de ser posto em função mastigatória. A previsibilidade do tratamento original levou ao desenvolvimento de técnicas com o objetivo de simplificar o procedimento, reduzindo o período de cicatrização, baixando custos e finalizando o tratamento protético em até 24 horas após a cirurgia.

O primeiro trabalho de carga imediata no sistema Branemark foi publicado por Schnitman et al. (1990). Neste estudo, 5 a 6 implantes foram colocados na região anterior da mandíbula de cada paciente, juntamente com 2 implantes distais. 
Os pilares foram conectados imediatamente no ato cirúrgico aos 2 implantes distais e a 1 implante na região da sínfise. Os implantes remanescentes foram utilizados como controle e deixou-se que cicatrizassem de forma tradicional. Uma prótese fixa pré-fabricada foi instalada sobre os 3 implantes expostos. Os autores concluíram que o tratamento não foi influenciado negativamente por essa técnica. Em 1997, Schnitman et al. publicaram o resultado da avaliação após 10 anos dos mesmos implantes e os resultados mantiveram-se estáveis.

Ericsson et al. (1994) descreveram uma técnica de instalar o pilar de conexão no mesmo dia da colocação dos implantes, ao invés de aguardar de 3 a 6 meses para o período de osseointegração. Os autores observaram que, passado o primeiro ano de acompanhamento, a perda óssea ao redor dos implantes em mandíbula na região anterior era de $1 \mathrm{~mm}$, independente dos implantes terem sido feitos em um ou dois estágios cirúrgicos. A mesma equipe publicou um controle de 5 anos destes implantes, e a osseointegração e o tecido ósseo marginal permaneceram estáveis (ERICSSON et al., 2000).

O conceito de função ou carga imediata vem sendo melhor compreendido e hoje é considerado uma alternativa segura de tratamento na reabilitação de pacientes total ou parcialmente edêntulos (BIJLANI; LOZADA, 1996; BUSER et al., 1988; CHIAPASCO et al., 1997; COLOMINA, 2001; COOPER et al., 2001; RANDOW et al., 1999; SALAMA et al., 1995).

A carga imediata é ainda mais favorável quando se trata da utilização de implantes inicialmente para ancoragem ortodôntica, que estejam fora de oclusão, isto porque a força ortodôntica provocaria um aumento muito suave no estresse da interface osso-implante (CHEN et al., 1995).

Neste sentido, os resultados clínicos, radiográficos e histológicos obtidos neste trabalho indicam a possibilidade de utilizar carga imediata sobre implantes osseointegráveis para ancoragem ortodôntica e demonstram a possibilidade destes parafusos serem aproveitados para posterior reabilitação protética.

Contudo, há se destacar que a decisão sobre o tempo de espera antes da carga é um parâmetro completamente clínico, e deve ser ajustado, de maneira individual, a cada um dos pacientes. Esta decisão clínica é guiada por parâmetros bem estabelecidos na literatura e que não devem ser negligenciados durante a 
execução do tratamento (CHEN et al., 1995; ESPOSITO et al., 2007; GAPSKI et al., 2003; MISCH et al., 2004a,2004b). Estes fatores são divididos em 4 categorias: (1) fatores relacionados à cirurgia - estabilidade primária e técnica cirúrgica; (2) fatores relacionados ao hospedeiro - qualidade e quantidade de tecido ósseo cortical e trabecular, cicatrização, atividade de remodelação óssea; (3) fatores relacionados ao implante - desenho, superfície, dimensão; e (4) fatores oclusais - qualidade e quantidade de forças e desenho da prótese.

Nesse sentido, se o clínico for capaz de identificar e reunir em cada paciente características favoráveis ao uso da carga imediata, ele poderá, com base nos resultados deste trabalho e na literatura (ESPOSITO et al., 2007; GAPSKI et al., 2003; MISCH et al., 2004a,2004b), oferecer aos seus pacientes conforto, rapidez e menores custos para o tratamento.

\subsection{Sugestões para Futuros Estudos}

1. Realizar análise histomorfométrica nos cortes histológicos desta pesquisa, na tentativa de quantificar a perda óssea em milímetros e desta forma comparar aos resultados clínicos e radiográficos;

2. Realizar avaliação histológica, neste mesmo protocolo, após a remoção da força ortodôntica, para verificar se o processo de remodelação se estabiliza após remoção da carga;

3. Testar, em animais, se existe travamento mínimo durante a instalação para a aplicação de carga imediata em implantes osseointegráveis convencionais;

4. Realização de um estudo clínico controlado com o objetivo de comprovar a eficiência da carga imediata sobre implantes osseointegráveis para ancoragem ortodôntica e a possibilidade destes implantes serem utilizados para reabilitação protética. 
7. Conclus̃̃es 



\section{CONCLUSÕES}

Com fundamento nos resultados apresentados rejeita-se a hipótese nula de que não há diferença para a perda óssea ao redor de implantes osseointegráveis mantidos sem carga durante período de reparo de 120 dias, implantes submetidos a interferências oclusais e implantes que receberam carga imediata para ancoragem ortodôntica. Os implantes mantidos sem carga e os implantes que receberam carga ortodôntica imediata apresentaram maior taxa de sucesso, menor perda óssea em altura e maior interação osso/implante em relação aos implantes submetidos a interferências oclusais. 

Referências 



\section{REFERÊNCIAS}

Adell R, Eriksson B, Lekholm U, Branemark PI, Jemt T. Long-term follow-up study of osseointegrated implants in the treatment of totally edentulous jaw. Int $\mathrm{J}$ Oral Maxillofac Implants. 1990;5:347-59.

Adell R, Lekholm U, Branemark PI, Lindhe J, Rockler B, Eriksson B, et al. Marginal tissue reactions at osseointegrated titanium fixtures. Swedish Dent J. 1985;28:17581.

Adell R, Lekholm U, Rockler B, Branemark PI. A 15-year study of osseointegrated implants in the treatment of the edentulous jaw. Int J Oral Surg. 1981;10(6):387-416.

Albrektsson T, Zarb GA. Current interpretations of the osseointegrated response: clinical significance. Int J Prosthodont. 1993;6:95-105.

Albrektsson T, Zarb GA, Worthington P, Eriksson AR. The long-term efficacy of currently used dental implants: a review and proposed criteria of success. Int $\mathrm{J}$ Oral Maxillofac Implants. 1986;1:11-25.

Aldikaçti M, Açikgöz G, Türk T, Trisi P. Long-term evaluation of sandblasted and acid-etched implants used as orthodontic anchors in dogs. Am J Orthod Dentofac Orthop. 2004;125:139-47.

Anderson JM, Miller KM. Biomaterial biocompatibility and the macrophage. Biomaterials. 1984;5(1):5-10.

Araújo MG, Carmagnola D, Berglundh $T$, Thilander $B$, Lindhe J. Orthodontic movement in bone defects augument with Bio-Oss: An experimental study in dogs. J Clin Periodontol. 2001;28(1):73-80.

Bae S, Park H, Kyung $\mathrm{H}$, Kwon O, Sung J. Clinical application of micro-implant anchorage. J Clin Orthod. 2002;36(5):298-302. 
Barzilay I, et al. Immediate implantation of a pure titanium implant into an extraction socket: a report of a pilot procedure. Int J Oral Maxillofac Implants. 1991;6:277-84.

Bender I. Factors inflencing the radiographic appearence of bony lesions. J Endod. 1982;8(4):161.

Bijlani M, Lozada J. Immediately loaded dental implants - influence of early functional contacts on implant stability, bone level integrity, and soft tissue quality: a retrospective 3 and 6 year clinical analysis. Int $\mathrm{J}$ Oral Maxillofac Implants. 1996;11:126-7.

Block M, Hoffman D. A new device for absolute anchorage for orthodontics. Am J Orthod Dentofac Orthop. 1995;107(3):251-8.

Block MS, Kent JN. Placement of endosseous implants into tooth extraction sites. J Oral Maxillofac Surg. 1991;49:1269-76.

Branemark P, Adell R, Breine U, Hansson B, Lindstrom J, Ohlsson A. Intra-osseous anchorage of dental prostheses. I. Experimental studies. Scand J Plast Reconstr Surg. 1969a;3(2):81-100.

Branemark P, Breine U, Adell R, Hansson BO, Ohsson A. Intraosseous anchorage of dental prostheses. Part I: experimental studies. Scand J Plast Reconstr Surg. 1969b;3:81-100.

Branemark PI, Hansson BO, Adell R, Breine U, Lindstrom J, Hallem O, et al. Osseointegrated implants in the treatment of the edentulous jaw. Experience from a 10-year period. Scand J Plast Reconstr Surg. 1977;16:1-132.

Büchter A, Wiechmann D, Gaertner C, Hendrik M, Vogeler M, Wiesmann HP, et al. Load-related bone modelling at the interface of orthodontic micro-implants. Clin Oral Implants Res. 2006;17(6):714-22. 
Büchter A, Wiechmann D, Koerdt S, Wiesmann HP, Piffko J, Meyer U. Load-related implant reaction of mini-implants used for orthodontic anchorage. Clin Oral Implants Res. 2005;16(4):473-9.

Buck D, Weaver M. Tooth movement in miniature swine labeled with tetracycline. J Dent Res. 1965;44:450.

Büchter A, Wiechmann D, Koerdt S, Wiesmann H, Piffko J, Meyer U. Load-related implant reaction of mini-implants used for orthodontic anchorage. Clin Oral Implants Res. 2005;16:473-9.

Buser D, Schroeder A, Sutter F, Lang N. A new concept of ITI hollow-cylinder and hollow-screw implants: part 2. Clinical aspects, indications, and early clinical results. Int J Oral Maxillofac Implants. 1988;3:173-81.

Bustad L, McClellan R. Use of pigs in biomedical research. Nature. 1965;208:531-5.

Bustad L, McClellan R. Miniature swine: development, management and utilization. Lab Anim Care. 1968;18(2):280-7.

Cehreli M, Akkocaoglu M, Comert A, Tekdemir I, Akca K. Human ex vivo bone tissue strains around natural teeth vs. immediate oral implants. Clin Oral Implants Res. 2005;16:540-8.

Celenza F, Hochman M. Absolute anchorage in orthodontics: direct and indirect implant-assisted modalities. J Clin Orthod. 2000;34(7):397-402.

Chen J, Chen L, Garetto LP, Roberts WE. Mechanical response to functional and therapeutic loading of a retromolar endosseous implant used for orthodontic anchorage to mesially translate mandibular molars. Implant Dent. 1995;4:246-58.

Cheung LK, Shi XJ, Zheng LW. Surgical induction of temporomandibular joint ankylosis: an animal model. J Oral Maxillofac Surg. 2007;65(5):993-1004. 
Chiapasco M, Gatti C, Rossi E, Haefliger W, Markwalder T. Implant-retained mandibular overdentures with imediatic loading. A retrospective multicenter study on 226 consecutive cases. Clin Oral Implants Res. 1997;8:48-57.

Chung K, Kim S, Kook Y. C-orthoodntic microimplant for distalization of mandibular dentition in Class III correction. Angle Orthod. 2005;75(1):119-28.

Cochran D, Schenk R, Lussi A, Higginbottem F, Buser D. Bone response to unloaded and loaded titanium implants with a sandblasted and acid etched surface. $\mathrm{J}$ Biomed Mat Res. 1998;40:1-11.

Colomina L. Immediate loading of implant-fixed mandibular prostheses: a prospective 18-month follow-up clinical study - preliminary report. Implant Dentistry. 2001;10:239.

Conti PCR. Patologias oclusais e Disfunções Temporomandibulares: Considerações relacionadas à Prótese Fixa e Reabilitação Oral. In: Pegoraro LF, editor. Prótese Fixa. São Paulo: Artes Médicas; 1998. p. 23-41.

Cooper L, Felton D, Kugelberg C, Ellner S, Chafee N, Molina A, et al. A multicenter 12-month evaluation of single-tooth implants restored 3 weeks after one stage surgery. Int J Oral Maxillofac Implants. 2001;16:182-92.

Cordeiro R, Leonardo M, Silva A, Cerri P. Desenvolvimento de um dispositivo para padronização de tomadas radiográficas em cães. RPG. 1995;2(3):138-40.

Creekmore T, Eklund M. The possibility of skeletal anchorage. J Clin Orthod. 1983;17:266-9.

Cuoghi O. Avaliação dos primeiros momentos da movimentação dentária induzida: estudo microscópico em macacos da espécie Cebus apella. Bauru: Faculdade de Odontologia de Bauru, Universidade de São Paulo; 1996. 
Dahlberg G. Statistical methods for medical and biological students. New York: Interscience Publications; 1940.

De Pauw G, Dermaut L, DeBruyn H, Johansson C. Stability of implants an anchorage for orthopedic traction. Angle Orthod. 1999;68(5):401-7.

Eisner E. Problems associated with veterinary dental radiography. Probl Vet Med. $1990 ; 2(1): 46-84$.

Eisner E. Oral-dental radiographic examination technique. Vet Clin North Am Small Anim Pract. 1998;28(5):1063-87.

England D, Winters L, Carpenter L. The development of breed of miniature swine: a preliminary report. Growth. 1954;18(4):207-14.

Ericsson I, Radow K, Nilner K, Peterson A. Early functional loading of Branemark dental implants: 5-year clinical follow-up study. Clin Implants Dent Relat Res. $2000 ; 2: 70-7$.

Ericsson I, Randow K, Glantz PO, Lindhe J, Nilner K. Clinical and radiographical features of submerged and nonsubmerged titanium implants. Clin Oral Implants Res. 1994;5(3):185-9.

Esposito M, Grusovin MG, Willings M, Coulthard P, Worthington HV. The effectiveness of immediate, early, and conventional loading of dental implants: a Cochrane systematic review of randomized controlled clinical trials. Int $\mathrm{J}$ Oral Maxillofac Implants. 2007;22(6):893-904.

Everdi N, Keles A, Nanda R. Orthodontic anchorage and skeletal implants. In: Nanda $\mathrm{R}$, editor. Biomechanics and esthetic strategies in clinical orthodontics. St Louis: Elsevier Saunders; 2005. p. 385.

Favero L, Brollo P, Bressan E. Orthodontic anchorage with specific fixtures: related study analysis. Am J Orthod Dentofac Orthop. 2002;122:84-94. 
Ferrari CS, Herring SW. Use of a bite-opening appliance in the miniature pig: modification of craniofacial growth. Acta anatomica. 1995;154(3):205-15.

Ferreira N. Avaliação clínica e radiográfica de implantes osseointegrados em função, submetidos à ancoragem ortodôntica para movimentação de dentes naturais. [Mestrado]. Bauru: Universidade do Sagrado Coração; 2002.

Francischone CE, Akashi AE, Vasconcelos LW, Francischone AC, Francischone Jr CE. O Implante no tratamento multidisciplinar. In: Bottino MA, editor. Clínica Odontológica Brasileira - Livro do Ano. São Paulo: Artes Médicas; 2004. p. 384-406.

Francischone CE, Oltramari PVP, Vasconcelos LW, Francischone AC, Capelozza Filho L, Henriques JF. Treatment for predictable multidisciplinary implantology, orthodontics, and restorative dentistry. Pract Proced Aesthet Dent. 2003;15(4):321-6.

Francischone CE, Vasconcelos LW. Otimização estética das próteses unitárias sobre implantes. In: Francischone CE, Vasconcelos LW, editors. Osseointegração e as próteses unitárias: como otimizar a estética. São Paulo: Artes Médicas; 1998. p. 79107.

Francischone Jr CE, Tuler R, Laurenti J, Garcia R. Carga ou função imediata em implantes osseointegrados. In: Francischone CE, editor. Osseointegtação e o tratamento multidisciplinar. São Paulo: Quintessence; 2006. p. 175-99.

Gainsforth B, Higley L. A study of orthodontic anchorage possibilities in basal bone. Am J Orthod Oral Surg. 1945;31:406-17.

Gallas M, Abeleira M, Fernández J, Burguera M. Three-dimensional numerical simulation of dental implants as orthodontic anchorage. Eur J Orthod. 2005;27:12-6.

Gapski R, Wang H, Mascarenhas P, Lang N. Critical review of immediate implant loading. Clin Oral Implants Res. 2003;14:515-27. 
Garg AK. Analyzing dental occlusion for implants: Tekscan's TScan III. Dent Implantol Update. 2007;18(9):65-70.

Gedrange T, Köbel C, Harzer W. Hard Palate deformation in animal model following quasi-statistic loading to stimulate that of orthodontic anchorage implants. Eur $\mathrm{J}$ Orthod. $2001 ; 23(4): 349-54$.

Giunta D, Keller J, Nielsen F, Melsen B. Influence of indomethacin on bone turnover related to orthodontic tooth movement in miniature pigs. Am J Orthod Dentofac Orthop. 1995;108(4):361-6.

Glatzmaier J, Wehrebein H, Diedrich P. The development of a resorbable implant system for orthodontic anchorage. The BIOS implant system. Bioresorbable implant anchor for orthodontic system. Fortschr Kieferorthop. 1995;56:175-8.

Glatzmaier J, Wehrebein H, Diedrich P. Biodegradable implants for orthodontic anchorage. A preliminary biomechanical study. . Eur J Orthod. 1996;18:465-9.

Gotfredsen K, Berglundh T, Lindhe J. Bone reactions adjacent to titanium implants subjected to static load: a study in the dog (I). Clin Oral Implants Res. 2001;12:1-8.

Gray J, Steen M, King G, Clark A. Studies on the efficiency of implants as orthodontic anchorage. Am J Orthod Dentofac Orthop. 1983;83:311-7.

Haas A. Rapid expansion of the maxillary dental arch and nasal cavity by opening the midpalatal suture. Angle Orthod. 1961;31(1):73-90.

Herford AS, Hoffman R, Demirdji S, Boyne PJ, Caruso JM, Leggitt VL, et al. A comparison of synovial fluid pressure after immediate versus gradual mandibular advancement in the miniature pig. J Oral Maxillofac Surg. 2005;63:775-85.

Herring S. Animal models of temporomandibular disorders: how to choose. Temporomandibular disorders and related pain conditions, progress in pain research and management. In: Sessle B, Bryant P, Dionne R, editors. Temporomandibular 
Disorders and Related Pain Conditions, Progress in Pain Research and Manegement. Seattle: IASP Press; 1995. p. 323-8.

Herrmann I, Lekholm U, Holm S, Kultje C. Evaluation of patient and implant characteristics as potential prognostic factors for oral implant failures. Int $\mathrm{J}$ Oral Maxillofac Impl. 2005;20(2):220-30.

Higuchi K. Osseointegration and orthodontics. In: Branemark PI, editor. The osseointegration book. Berlim: Quintessence; 2005. p. 251-69.

Higuchi KW, Slack JM. The use of titanium fixtures for intraoral anchorage to facilitate orthodontic tooth movement. Int J Oral Maxillofac Implants. 1991;6(3):338-44.

Holzhauer DP, Larsen PE, Miloro M, Vig KW. Distraction osteogenesis of the mandible with a modified intraoral appliance: a pilot study in miniature pigs. Int $\mathrm{J}$ Adult Orthodon Orthognath Surg. 1998;13(3):241-7.

Hoshaw SJ, Brunski JB, Cochran GVB. Mechanical loading of Branemark implants affects interfacial bone modeling and remodeling. Int $\mathrm{J}$ Oral Maxillofac Implants. 1994;9:345-60

Houston W. Analysis of errors in orthodontics measurements. Am J Orthod Dentofac Orthop. 1983;83(5):382-90.

Huang L, Shotwell J, Wang H. Dental implants for orthodontic anchorage. Am J Orthod Dentofac Orthop. 2005;127:713-22.

Isidor F. Loss of osseointegration caused by occlusal load of oral implants. A clinical and radiographic study in monkeys. Clin Oral Implants Res. 1996;7(2):143-52.

Jahangiri L, Hessamfar R, Ricci J. Partial generation of periodontal ligament on endosseous dental implants in dogs. Clin Oral Implants Res. 2005;16:396-401. 
Jensen T, Turek T. Improved radiography in endodontic practice. A procedure and an instrument. J Endod. 1978;4(3):82-7.

Kanomi R. Mini-implant for orthodontic anchorage. J Clin Orthod. 1997;31(11):763-7.

Kawamoto T, Motohashi N, Kitamura A, Baba Y, Suzuki S, Kuroda T. Experimental tooth movement into bone induced by recombinant human bone morphogenetic protein-2. Cleft Palate Craniofac J. 2003;40(5):538-43.

Kawamoto T, Motohashi N, Kitamura A, Baba Y, Takahashi K, Suzuki S, et al. A histological study on experimental tooth movement into bone induced by recombinant human bone morphogenetic protein-2 in beagle dogs. Cleft Palate Craniofac J. 2002;39(4):439-48.

Kokich V. Orthodontic Applications of Osseointegrated Implants. Illinois: Quintessence; 2000.

Kraut R, Hammer H, Wheeler J. Use of endosteal implants as orthodontic anchorage. Compend Contin Educ Dent. 1988;9(10):796-7, 800-1.

Krump JL, Barnett BG. The immediate implant: a treatment alternative. Int J Oral Maxillofac Impl. 1991;6:19-23.

Lee J, Kim D, Park Y, Kyung S, Kim T. The efficient use of midpalatal miniscrew implants. Angle Orthod. 2004;74(5):711-4.

Lee J, Park $\mathrm{H}$, Kyung $\mathrm{H}$. Micro-implant anchorage for lingual treatment of a skeletal Class II Malocclusion. J Clin Orthod. 2001;35(10):643-7.

Liebenberg W. The use of endosseous implant for anchorage during the orthodontic movement of a molar using an upright abutment. $J$ Dent Assoc $S$ Afr. $1996 ; 21(3): 125-9$. 
Linder-Aronson S, Nordenram A, Anneroth G. Titanium implant anchorage in orthodontic treatment: an experimental investigation in monkeys. Eur $\mathrm{J}$ Orthod. 1990;12(4):414-9.

Linkow L. The endosseous blade implant and its use in orthodontics. Int $\mathrm{J}$ Orthod. 1969;18:149-53.

Linkow L. Implanto-Orthodontics. J Clin Orthod. 1970;4(11):685-705.

Lorenzoni M, Pertl C, Zhang K, Wimmer G, Wegscheider W. Immediate loading of single-tooth implants in the anterior maxilla. Preliminary results after one year. Clin Oral Implants Res. 2003;14:180-7.

Lundgren A, Sennerby L, Lundgren D. An experimental rabbit model for jaw-bone healing. Int Oral Maxillofac Impl. 1997;26(6):461-4.

Machado L. Os Suínos: A Granja; 1967.

Mariano M. The miniature pig (minipig) in biomedical experimental research: BR-1 minipig. Acta Cir Bras (serial online). 2003;18(5):1-9.

Massone F. Anestesiologia veterinária: farmacologia e técnicas. Rio de Janeiro: Guanabara Koogan; 1994.

McKean C, Jump E, Weaver M. The calcification pattern of deciduous teeth in miniature swine. Arch Oral Biol. 1971;16(6):639-48.

Mellonig JT. Human histologic evaluation of a bovine-derived bone xenograft in the treatment of periodontal osseous defects. Int J Periodontics Restorative Dent. 2000;20(1):19-29.

Melsen B. Tissue reaction following application of intrusive and extrusive forces on teeth in adult monkeys. Am J Orthod Dentofac Orthop. 1986;89:469-76. 
Melsen B, Costa A. Immediate loading of implants used for orthodontic anchorage. Clin Orthod Res. 2000;3:23-8.

Melsen B, Lang N. Biological reactions of alveolar bone to orthodontic loading of oral implants. Clin Oral Implants Res. 2001;12:144-52.

Meyer U, Joos U, Mythili J, Stamm T, Hohoff A, Fillies T, et al. Ultrastructural characterization of the implant/bone interface of immediately loaded dental implants. Biomaterials. 2004;25:1959-67.

Misch C. Immediate loading of definitive implant in the edentulous mandible using a fixed provisional prosthesis: the denture conversion technique. J Oral Maxillofac Surg. 2004;62(2):106-15.

Misch C, Wang H, Misch C, Sharawy M, Lemons J, Judy K. Rationale for the application of immediate load in implant dentistry: Part I. Implant Dentistry. 2004a;13(3):207-16.

Misch C, Wang H, Misch C, Sharawy M, Lemons J, Judy K. Rationale for the application of immediate load in implant dentistry: Part II. Implant Dentistry. 2004b;13(4):310-21.

Misch CE, Bidez MW. Considerações sobre oclusão das próteses implantosuportadas: oclusão protetora do implante e materiais oclusais. In: Misch CE, editor. Implantes Dentários Contemporâneos. São Paulo: Santos; 2000. p. 609-28.

Navarro RL, Oltramari PVP, Henriques JFC, Capelozza AL, Sant'ana E, Granjeiro JM. Radiographic techniques for medical-dental research with minipigs. Vet J. 2007;174(1):165-9.

Navarro RL, Oltramari PVP, Sant'Ana E, Henriques JFC, Taga R, Cestari TM, et al. Histological and molecular temporomandibular joint analyses after mandibular advancement surgery: study in minipigs. Oral Surg Oral Med Oral Pathol Oral Radiol Endod. 2008;106(3):331-8. 
Navarro RL, Oltramari PVP, Sant'Ana E, Henriques JFC, Taga R, Cestari TM, et al. Histological and tomographic analyses of the temporomandibular joint after mandibular advancement surgery: study in minipigs. Oral Surg Oral Med Oral Pathol. 2008; In Press.

Neugebauer J, Traini T, Thams U, Piattelli A, Zöller J. Peri-implant bone organization under immediate loading state. Circularly polarized light analyses: a minipig study. J Periodontol. 2006;77(2):152-60.

Nkenke E, Fenner M, Vairaktaris E, Neukam F, Radespiel-Tröger M. Immediate versus delayed loading of dental implants in the maxillae of minigpis. Part II: histomorphometric analysis. Int J Oral Maxillofac Implants. 2005a;20(4):540-6.

Nkenke E, Lehner B, Fenner M, Roman F, Thams U, Neukam F, et al. Immediate versus delayed loading of dental implants in the maxillae of minipigs: follow-up of implant stability and implant failures. Int J Oral Maxillofac Implants. 2005b;20(1):3947.

Nkenke E, Lehner B, Weinzierl K, Thams U, Neugebauer J, Steveling H, et al. Bone contact, growth, and density around immediately loaded implants in the mandible of minipigs. Clin Oral Implants Res. 2003;14:312-21.

Noguchi K, Kuroda T, Nakamura T. The miniature pig as an experimental animal in dental research, especially in orthodontics (author's transl). Kokubyo Gakkai Zasshi. 1976;43(1):87-91.

Novaes $A B$, Novaes Jr AB. Immediate implants placed into infected sites: a clinical report. Int J Oral Maxillofac Impl. 1995;10:609-13.

Ödman J, Ekholm U, Jemt T, Branemark P, Thilander B. Osseointegrated titanium implants - a new approach in orthodontic treatment. Europ J Orthod. 1988;10:98-105. 
Ödman J, Gröndahl K, Lekholm U, Thilander B. The effect of osseointegrated implants on the dentoalveolar development. A clinical and radiographic study in growing pigs. Eur J Orthod. 1991;13(4):279-86.

Ödman J, Lekholm U, Jemt T, Thilander B. Osseointegrated implants as orthodontic anchorage in the treatment of partially edentulous adult patients. Europ $\mathrm{J}$ Orthod. 1994;16:187-201.

Ohmae M, Saito S, Morohashi T, Seki K, Qu H, Kanomi R, et al. A clinical and histological evaluation of titanium mini-implants as anchors for orthodontic intrusion in the beagle dog. Am J Orthod Dentofac Orthop. 2001;119(5):489-97.

Ohnishi H, Yagi T, Yasuda Y, Takada K. A mini-implant for orthodontic anchorage in a deep overbite case. Angle Orthod. 2005;75(3):444-52.

Oltramari PVP, Conti AC, Navarro RL, Almeida MR, Almeida-Pedrin RR, Ferreira FP. Importance of occlusion aspects in the completion of orthodontic treatment. Braz Dent J. 2007a;18(1):78-82.

Oltramari PVP, Navarro RL, Henriques JFC, Taga R, Cestari TM, Janson G, et al. Evaluation of bone height and bone density after tooth extraction: an experimental study in minipigs. Oral Surg Oral Med Oral Pathol Oral Radiol Endod. 2007b;104(5):e9-16.

Oltramari PVP, Navarro RL, Henriques JFC, Capelozza AL, Granjeiro JM. Dental and skeletal characterization of the BR-1 minipig. Vet J. 2007c;173(2):399-407.

Oltramari PVP, Navarro RL, Henriques JFC, Taga R, Cestari TM, Ceolin DS, et al. Orthodontic movement in bone defects filled with xenogenic graft: study in minipigs. Am J Orthod Dentofac Orthop. 2007;131(3):302.e10-.e17.

Oyonarte R, Pilliar R, Deporter D, Woodside D. Peri-implant bone response to orthodontic loading: Part 2. Implant surface geometry and its effect on regional bone remodeling. Am J Orthod Dentofac Orthop. 2005a;128(2):182-9. 
Oyonarte R, Pilliar R, Deporter D, Woodside D. Peri-implant bone response to orthodontic loading: Part 1. A histomorphometric study of the efects of implant surface design. Am J Orthod Dentofac Orthop. 2005b;128(2):173-81.

Panepinto L, Philips R. The Yucatan miniature pig: characterization and utilization in biomedical research. Lab Anim Sci. 1986;36(4):344-7.

Park H, Bae S, Kyung H, Sung J. Micro-implant anchorage for treatment of skeletal Class I bialveolar protrusion. J Clin Orthod. 2001;35(7):417-22.

Park $\mathrm{H}$, Kwon T. Sliding mechanics with microscrew implant anchorage. Angle Orthod. 2004;74(5):703-10.

Park $\mathrm{H}$, Kwon $\mathrm{T}$, Kwon O. Treatment of open bite with microscrew implant anchorage. Am J Orthod Dentofac Orthop. 2004a;126(5):627-36.

Park H, Kwon T, Sung J. Nonextraction treatment with microscrew implants. Angle Orthod. 2004b;74(4):539-49.

Park $\mathrm{H}$, Lee S, Kwon O. Group distal movement of teeth using microscrew implant anchorage. Angle Orthod. 2005;75(4):602-9.

Park Y, Lee S, Kim D, Jee S. Intrusion of posterior teeth using mini-screw implants. Am J Orthod Dentofac Orthop. 2003;123(6):690-4.

Petrie CS, Williams JL. Probabilistic analysis of peri-implant strain predictions as influenced by uncertainties in bone properties and occlusal forces. Clin Oral Implants Res. 2007;18(5):611-9.

Pikner SS, Gröndahl K, Jemt T, Friberg B. Marginal bone loss at implants: a retrospective, long-term follow-up of turned Branemark System® implants. Clin Implant Dent Relat Res. 2008. 
PittFord T. The radiographic detection of periapical lesions in dogs. Oral Surg Oral Med Oral Pathol. 1984;57:662-7.

Polizzi G, et al. Immediate and delayed implant placement into extraction sockets: 5 year report. Clin Implant Dent Relat Res. 2000;2(2):93-9.

Proffit W, Fields Jr H. The biological basis of orthodontic therapy. Contemporary Orthodontics Third Edition ed. St Louis: Mosby; 2000. p. 296-325.

Prosterman B, Prosterman L, Fisher R, Gornitsky M. The use of implants for orthodontic correction of an open bite. Am J Orthod Dentofac Orthop. 1995;107:24550.

Randow K, Ericsson I, Nilner K, Petersson A, Glantz P. Immediatic functional loading of Branemark dental implants. An 18-month clinical follow-up study. Clin Oral Implants Res. 1999;140:8-15.

Rimondini L, Bruschi G, Scipioni A, Carrassi A, Nicoli-Aldini N, Giavaresi G, et al. Tissue healing in implants immediately placed into postextraction sockets: a pilot study in a mini-pig model. Oral Surg Oral Med Oral Pathol Oral Radiol Endod. 2005;100:E43-50.

Roberts-Harry D, Sandy J. Orthodontics. Part 9: Anchorage control and distal movement. Brit Dent J. 2004;196(5):255-63.

Roberts W, Gordon R, Mostafa A. Rate of mesial translation of mandibular molars using implant-anchored mechanics. Angle Orthod. 1996;66(5):331-8.

Roberts W, Helm F, Marshall K, Gongloff R. Rigid endosseous implants for orthodontic and orthopedic anchorage. Angle Orthod. 1989;59(4):247-56.

Roberts W, Marshall K, Mozsary P. Rigid endosseous implant utilized as anchorage to protract molars and close an atrophic extraction site. Angle Orthod. 1990;60:13552. 
Roberts W, Nelson C, Goodcare C. Rigid implant anchorage to close a mandibular first molar extraction site. J Clin Orthod. 1994;28:693-703.

Roberts WE, Poon LC, Smith RK. Interface histology of rigid endosseous implants. J Oral Implantol. 1986;12:406-16.

Roberts WE, Smith RK, Zilberman Y, Mozsary PG, Smith RS. Osseous adaptation to continuous loading of rigid endosseous implants. Am J Orthod Dentofac Orthop. 1984;86(2):95-111.

Saito S, Sugimoto N, Morohashi T, Ozeki M, Kurabayashi H, Shimizu H, et al. Endosseous titanium implants as anchors for mesial tooth movement in the beagle dog. Am J Orthod Dentofac Orthop. 2000;118(6):601-7.

Salama H, Rose L, Salama M, Betts N. Immediate loading of bilaterally splinted titanium root-form implants in fixed prosthodontics - a technique reexamined: two case reports. Int J Period Rest Dent. 1995;15:344-61.

Schaberg S, Petri W, Gregory E, Auclair P, Jacob E. A comparison of freeze-dried allogenic and fresh autologous vascularized rib grafts in dog radial discontinuity defects. J Oral Maxillofac Surg. 1985;43(12):932-7.

Schierano G, Canuto R, Navone R, Peirone B, Martinasso G, Pagano M, et al. Biological factors involved in the osseointegration of oral titanium implants with different surfaces: a pilot study in minipigs. J Periodontol. 2005;76(10):1710-20.

Schnitman PA, Wöhrle PS, Rubenstein JE. Immediate fixed interim prostheses supported by two-stage. Threaded implants: methodology and results. J Oral Implants. 1990;16(2):96-105.

Schnitman PA, Wöhrle PS, Rubenstein JE, DaSilva JD, Wang NH. Ten-year results for Branemark implants immediately loaded with fixed prostheses at implant placement. Int J Oral Maxillofac Implants. 1997;12:495-503. 
Schou S, et al. Autogenous bone graft and ePTFE membrane in the treatment of peri-implantitis. II. Stereologic and histologic observations in cynomolgus monkeys. Clin Oral Implants Res. 2003;14:404-11.

Sennerby L, Ericson LE, Thomsen P, Lekholm U, Astrand P. Structure of the bonetitanium interface in retrieved clinical oral implants. Clin Oral Implants Res. $1991 ; 2(3): 103-11$.

Sennerby L, Ödman J, Lekholm U, Thilander B. Tissue reactions towards titanium implants inserted in growing jaws. A histological study in the pig. Clin Oral Implants Res. 1993;4(2):65-75.

Shapiro P, Kokich V. Uses of implants in orthodontics. Dent Clin N Am. 1988;32(3):539-50.

Sheats R, Strauss R, Rubenstein L. Effect of a resorbable bone graft material on orthodontic tooth movement trough surgical defects in the cat mandible. J Oral Maxillofac Surg. 1991;49(12):1299-303.

Shellhart C, Moawad M, Lake P. Case report: implants as anchorage for molar uprighting and intrusion. Angle Orthod. 1996;66:169-72.

Sherman A. Bone reaction to orthodontic forces on vitreous carbon dental implants. Am J Orthod Dentofac Orthop. 1978;74(1):79-87.

Shufford EL, Kraut RA. Passive rigid fixation of sagittal split osteotomy. Oral Surgery, Oral Medicine, Oral Pathology. 1989;68(2):150-3.

Sindelar BJ, Herring SW. Soft tissue mechanics of the temporomandibular joint. Cells, tissues, organs. 2005;180(1):36-43.

Sindelar BJ, Herring SW, Alonzo TA. The effects of intraoral splints on the masticatory system of pigs. J Oral Rehabil. 2003;30(8):823-31. 
Sisson S, Grossman J. Anatomy of the domestic animals. Philadelphia: Saunders; 1959.

Smalley W. Implants for tooth movement: determining implant location and orientation. J Esthet Dent. 1995;7(2):62-72.

Smalley WM, Shapiro PA, Hohl TH, Kokich VG, Branemark PI. Osseointegrated titanium implants for maxillofacial protraction in monkeys. Am J Orthod Dentofac Orthop. 1988;94(4):285-95.

Smith J. Bone dynamics associated with controlled loading of bioglass-coated aluminium oxide endosteal implants. Am J Orthod Dentofac Orthop. 1979;76:618-36.

Sorenson N. Use of maxillary intraosseous implants for Class II elastic anchorage. Angle Orthod. 1995;65(3):169-73.

Stanford CM, Brand RA. Toward an understanding of implant occlusion and strain adaptive bone modeling and remodeling. J Prosthet Dent. 1999;81:553-61.

Swindle M. The use of animals in surgical research. J Invest Surg. 1988;1(1):3-4.

Swindle M. Anesthetic and preoperative techniques in swine: an update. 1994 [cited 2003 07/02/2003]; Available from: www.criver.com/techdocs/anesth.html

Swindle M, Moody D, Philips L. Swine as models in biomedical research. lowa: lowa Satate University Press; 1992.

Taylor TD. Fixed implant rehabilitation for the edentulous maxilla. Int $\mathrm{J}$ Oral Maxillofac Implants. 1991;6(3):329-37.

Thilander B, Ödman J, Gröndahl K, Friberg B. Osseointegrated implants in adolescents. An alternative in replacing missing teeth? Europ $\mathrm{J}$ Orthod. $1994 ; 16(2): 84-95$. 
Thilander B, Ödman J, Gröndahl K, Lekholm U. Aspects on osseointegrated implants inserted in growing jaws. A biometric and radiographic study in the young pig. Eur $\mathrm{J}$ Orthod. 1992;14(2):99-109.

Thurmuller P, Troulis MJ, Rosenberg A, Chuang SK, Kaban LB. Microscopic changes in the condyle and disc in response to distraction osteogenesis of the minipig mandible. J Oral Maxillofac Surg. 2006;64(2):249-58.

Thurmuller P, Troulis MJ, Rosenberg A, Kaban LB. Changes in the condyle and disc in response to distraction osteogenesis of the minipig mandible. J Oral Maxillofac Surg. 2002;60(11):1327-33.

Trisi P, Rebaudi A. Progressive bone adaptation of titanium implants during and after orthodontic load in humans. Int J Period Rest Dent. 2002;22(1):31-43.

Turley P. The loading of bioglass-coated aluminium oxide implants to produce sutural expansion of the maxillary complex in the pigtail monkey (Macaca menestrina). Arch Oral Biol. 1980;25:459-64.

Turley PK, Kean C, Schur J, Stefanac J, Gray J, Hennes J, et al. Orthodontic force application to titanium endosseous implants. Angle Orthod. 1988;58(2):151-62.

Umemori M. Skeletal anchorage system for open-bite correction. Am J Orthod Dentofac Orthop. 1999;115(2):166-74.

Urist M. Bone: formation by autoinduction. Science. 1965;150:893-99.

Van Roekel N. The use of Branemark system implants for orthodontic anchorage: report of a case. Int J Oral Maxillofac Implants. 1989;4:341-4.

Verna C, Dalstra M, Lee T, Cattaneo P, Melsen B. Microcracks in the alveolar bone following orthodontic tooth movement: a morphological and morphometric study. Eur J Orthod. 2004;26(5):459-67. 
Walton R. Endodontic radiographic techniques. Dent Radiogr Photogr. 1973;46(3):51-9.

Ward D, Behrents R, Goldberg J. Temporomandibular synovial fluid pressure response to altered mandibular positions. Am J Orthod Dentofac Orthop. 1990;98(1):22-8.

Weaver M, Jump E, McKean C. The eruption pattern of deciduous teeth in miniature swine. Anat Rec. 1966;154(1):81-6.

Weaver M, Jump E, McKean C. The eruption pattern of permanent teeth in miniature swine. Arch Oral Biol. 1969;14(3):323-31.

Weaver M, McKean C. Miniature swine as laboratory animals. Lab Anim Care. 1965;15(1):49-56.

Weaver M, Sorenson F, Jump E. The miniature pig as an experimental animal in dental research. Arch Oral Biol. 1962;7:17-24.

Wehrbein $\mathrm{H}$, Diedrich $\mathrm{P}$. Endosseous titanium implants during and after orthodontic load: an experimental study in the dog. Clin Oral Implants Res. 1993;4:76-82.

Wehrbein H, Fuhrmann RA, Diedrich PR. Human histologic tissue response after long-term orthodontic tooth movement. Am $J$ Orthod Dentofacial Orthop. 1995;107(4):360-71.

Wehrbein H, Glatzmaier J, Yildirim M. Orthodontic anchorage capacity of short titanium screw implants in the maxilla: an experimental study in the dog. Clin Oral Implants Res. 1997;8:131-41.

Wehrbein $\mathrm{H}$, Merz B. Aspects of the use of endosseous palatal implants in orthodontic therapy. J Esth Dent. 1998;10:315-24. 
Wehrbein H, Merz B, Diedrich P. Palatal bone support for orthodontic implant anchorage: a clinical and radiological study. Europ J Orthod. 1999;21:65-70.

Wehrbein H, Merz B, Diedrich P, Glatzmaier J. The use of palatal implants for orthodontic anchorage: design and clinical application of the Orthosystem. Clin Oral Implants Res. 1996;7:410-6.

Wehrbein H, Merz B, Hammerle C, Lang N. Bone-to-implant contact of orthodontic implants in humans subjected to horizontal loading. Clin Oral Implants Res. 1998;9:348-53.

Wenfield I, Magalhães L, Magalhães J, Villa N. Estudo histológico de um novo biomaterial (Biobone) indicado para reparação óssea. Rev Paul Odontol. 1999;4:810.

Young C, Sandstedt P, Skoglund A. A comparative study of anorganic xenogenic bone and autogenous bone implants for bone regeneration in rabbits. Int $\mathrm{J}$ Oral Maxillofac Implants. 1999;14(1):72-6.

Zhang G, Huang X, Herring SW. Effect of unilateral bite splint on mastication in the miniature pig. J Oral Rehabil. 1994;21(5):613-22.

Zontine W. Dental radiographic technique and interpretation. Vet Clin North Am Small Anim Pract. 1974;4(4):741-62.

Zouhary KJ, Feinberg SE. Regeneration of the mandibular condyle in minipigs. J Oral Maxillofac Surg. 2006;64(3):565-6. 

Apêndice 



\section{APÊNDICE}

\section{A1. Coloração Azul de Toluidina}

\section{Ingredientes para a coloração}

Tetraborato de sódio

Azul de Toluidina

Pironina-G

\section{Preparo da Coloração}

-Solução A

$800 \mathrm{ml}$ de água destilada

$8 \mathrm{~g}$ de tetraborato de sódio

$8 \mathrm{~g}$ de azul de toluidina

Misturar durante 15 minutos em agitador magnético

-Solução B:

$200 \mathrm{ml}$ de água destilada

$2 \mathrm{~g}$ de Pironina-G

Misturar durante 15 minutos em agitador magnético

-Misturar solução A e B, durante 15 minutos, em agitador magnético.

-Filtrar duas vezes a mistura

Processo de coloração dos cortes histológicos

1. Agitar em água oxigenada a $10 \%$, durante 5 minutos;

2. Enxaguar em água destilada;

3. Secar delicadamente;

4. Corar em solução de Azul de Toluidina, durante 20 minutos;

5. Enxagüar em água destilada;

6. Secar em temperatura ambiente overnight

7. Aderir as lamínulas utilizando resina (Tecnnovit $\AA 7200$ VLC, Light-curing Embedding Resin, Heraeus Kulzer)

8. Polimerização em um sistema de precisão (EXAKT 402, Precision Adhesive Press, EXAKT) 
A2. Avaliação Radiográfica: Grupos 1-5, número das radiografias, medidas para perda óssea nos lados esquerdo (tensão) e direito (pressão) dos implantes osseointegráveis

\begin{tabular}{|c|c|c|c|}
\hline Grupo & $\begin{array}{l}\text { Número da } \\
\text { Radiografia }\end{array}$ & $\begin{array}{c}\text { Perda Óssea (mm) } \\
\text { Lado Esquerdo }\end{array}$ & $\begin{array}{c}\text { Perda Óssea (mm) } \\
\text { Lado Direito }\end{array}$ \\
\hline Grupo 1 & 1DIRa & 0,00 & 0,00 \\
\hline Grupo 1 & 3DIRa & 0,00 & 0,00 \\
\hline Grupo 1 & 5DIRa & 0,72 & 0,44 \\
\hline Grupo 1 & 5DIRb & 0,00 & 0,00 \\
\hline Grupo 1 & 5ESQa & 1,60 & 0,28 \\
\hline Grupo 1 & 2DIRa & 0,00 & 0,00 \\
\hline Grupo 1 & 2DIRb & 0,52 & 0,80 \\
\hline Grupo 1 & 2ESQa & 1,32 & 1,16 \\
\hline Grupo 1 & 2ESQb & 0,00 & 0,00 \\
\hline Grupo 1 & 4DIRa & 0,76 & 0,48 \\
\hline Grupo 1 & 4DIRb & 0,00 & 0,00 \\
\hline Grupo 1 & 4ESQa & 0,00 & 0,00 \\
\hline Grupo 2 & 4ESQb & 0,00 & 0,00 \\
\hline Grupo 2 & 6DIRa & 0,00 & 0,00 \\
\hline Grupo 2 & 6DIRb & 0,00 & 2,24 \\
\hline Grupo 2 & 6ESQa & 0,00 & 0,00 \\
\hline Grupo 2 & 6ESQb & 0,00 & 0,80 \\
\hline Grupo 2 & 10DIRa & 0,52 & 0,52 \\
\hline Grupo 3 & 9DIRb & 2,12 & 2,24 \\
\hline Grupo 3 & 11DIRb & 0,60 & 0,52 \\
\hline Grupo 3 & 11DIRf & 3,36 & 2,64 \\
\hline Grupo 3 & 12ESQa & 5,60 & 4,60 \\
\hline Grupo 3 & 12ESQf & 4,00 & 2,16 \\
\hline Grupo 4 & 7DIRb & 0,00 & 0,80 \\
\hline Grupo 4 & 7DIRd & 0,00 & 0,00 \\
\hline Grupo 4 & 7ESQc & 0,00 & 0,00 \\
\hline Grupo 4 & 7ESQd & 1,36 & 1,08 \\
\hline
\end{tabular}




\begin{tabular}{|c|c|c|c|}
\hline Grupo 4 & 8DIRb & 4,80 & 1,36 \\
\hline Grupo 4 & 8ESQc & 1,28 & 0,92 \\
\hline Grupo 4 & 11DIRe & 0,36 & 0,00 \\
\hline Grupo 4 & 11DIRa & 0,76 & 0,92 \\
\hline Grupo 4 & 11ESQb & 1,20 & 1,00 \\
\hline Grupo 4 & 12DIRe & 0,00 & 0,00 \\
\hline Grupo 4 & 12DIRf & 0,72 & 0,00 \\
\hline Grupo 4 & 12ESQc & 0,60 & 0,00 \\
\hline Grupo 4 & 12ESQe & 0,92 & 0,00 \\
\hline Grupo 5 & 7DIRa & 1,32 & 0,92 \\
\hline Grupo 5 & 7DIRc & 0,68 & 1,32 \\
\hline Grupo 5 & 7ESQa & 1,72 & 1,40 \\
\hline Grupo 5 & 7ESQb & 0,52 & 1,16 \\
\hline Grupo 5 & 8DIRa & 0,84 & 1,00 \\
\hline Grupo 5 & 8DIRc & 2,80 & 2,08 \\
\hline Grupo 5 & 8ESQa & 2,32 & 3,24 \\
\hline Grupo 5 & 8ESQb & 1,68 & 1,04 \\
\hline Grupo 5 & 9DIRa & 0,00 & 0,00 \\
\hline Grupo 5 & 9ESQb & 0,00 & 0,00 \\
\hline Grupo 5 & 9ESQc & 0,00 & 0,00 \\
\hline Grupo 5 & 11DIRc & 0,64 & 0,48 \\
\hline Grupo 5 & 11DIRd & 0,60 & 0,76 \\
\hline Grupo 5 & 11ESQa & 1,32 & 1,32 \\
\hline Grupo 5 & 11ESQc & 0,00 & 0,00 \\
\hline Grupo 5 & 12DIRd & 2,28 & 2,24 \\
\hline Grupo 5 & 12DIRg & 0,72 & 0,00 \\
\hline Grupo 5 & 12ESQb & 0,92 & 0,84 \\
\hline Grupo 5 & 12ESQd & 0,00 & 1,00 \\
\hline
\end{tabular}


A2. Avaliação Radiográfica - Erro do Método: Grupos 1-5, número das radiografias, primeira e segunda avaliações da perda óssea no lado esquerdo (tensão) dos implantes osseointegráveis

\begin{tabular}{|c|c|c|c|}
\hline Grupo & $\begin{array}{l}\text { Número da } \\
\text { Radiografia }\end{array}$ & $\begin{array}{c}\text { Perda Óssea (mm) } \\
\text { Lado Esquerdo } \\
\text { 1a Avaliação }\end{array}$ & $\begin{array}{c}\text { Perda Óssea (mm) } \\
\text { Lado Esquerdo } \\
\text { 2ª Avaliação }^{\text {a A }}\end{array}$ \\
\hline Grupo 1 & 1DIRa & 0,00 & 0,00 \\
\hline Grupo 1 & 3DIRa & 0,00 & 0,00 \\
\hline Grupo 1 & 5DIRa & 0,72 & 0,84 \\
\hline Grupo 1 & 5DIRb & 0,00 & 0,00 \\
\hline Grupo 1 & 5ESQa & 1,60 & 1,80 \\
\hline Grupo 1 & 2DIRa & 0,00 & 0,00 \\
\hline Grupo 1 & 2DIRb & 0,52 & 0,48 \\
\hline Grupo 1 & 2ESQa & 1,32 & 1,32 \\
\hline Grupo 1 & 2ESQb & 0,00 & 0,00 \\
\hline Grupo 1 & 4DIRa & 0,76 & 0,76 \\
\hline Grupo 1 & 4DIRb & 0,00 & 0,00 \\
\hline Grupo 1 & 4ESQa & 0,00 & 0,00 \\
\hline Grupo 2 & 4ESQb & 0,00 & 0,00 \\
\hline Grupo 2 & 6DIRa & 0,00 & 0,00 \\
\hline Grupo 2 & 6DIRb & 0,00 & 0,00 \\
\hline Grupo 2 & 6ESQa & 0,00 & 0,00 \\
\hline Grupo 2 & 6ESQb & 0,00 & 0,00 \\
\hline Grupo 2 & 10DIRa & 0,52 & 0,52 \\
\hline Grupo 3 & 9DIRb & 2,12 & 2,16 \\
\hline Grupo 3 & 11DIRb & 0,60 & 0,60 \\
\hline Grupo 3 & 11DIRf & 3,36 & 3,28 \\
\hline Grupo 3 & 12ESQa & 5,60 & 5,32 \\
\hline Grupo 3 & 12ESQf & 4,00 & 3,96 \\
\hline Grupo 4 & 7DIRb & 0,00 & 0,00 \\
\hline Grupo 4 & 7DIRd & 0,00 & 0,00 \\
\hline Grupo 4 & 7ESQc & 0,00 & 0,00 \\
\hline
\end{tabular}




\begin{tabular}{|c|c|c|c|}
\hline Grupo 4 & 7ESQd & 1,36 & 1,40 \\
\hline Grupo 4 & 8DIRb & 4,80 & 4,84 \\
\hline Grupo 4 & 8ESQc & 1,28 & 1,28 \\
\hline Grupo 4 & 11DIRe & 0,36 & 0,48 \\
\hline Grupo 4 & 11DIRa & 0,76 & 0,76 \\
\hline Grupo 4 & 11ESQb & 1,20 & 1,16 \\
\hline Grupo 4 & 12DIRe & 0,00 & 0,00 \\
\hline Grupo 4 & 12DIRf & 0,72 & 0,68 \\
\hline Grupo 4 & 12ESQc & 0,60 & 0,52 \\
\hline Grupo 4 & $12 \mathrm{ESQe}$ & 0,92 & 0,92 \\
\hline Grupo 5 & 7DIRa & 1,32 & 1,20 \\
\hline Grupo 5 & 7DIRc & 0,68 & 0,80 \\
\hline Grupo 5 & 7ESQa & 1,72 & 1,72 \\
\hline Grupo 5 & 7ESQb & 0,52 & 0,64 \\
\hline Grupo 5 & 8DIRa & 0,84 & 0,84 \\
\hline Grupo 5 & 8DIRc & 2,80 & 2,84 \\
\hline Grupo 5 & 8ESQa & 2,32 & 2,12 \\
\hline Grupo 5 & 8ESQb & 1,68 & 1,60 \\
\hline Grupo 5 & 9DIRa & 0,00 & 0,00 \\
\hline Grupo 5 & 9ESQb & 0,00 & 0,00 \\
\hline Grupo 5 & 9ESQc & 0,00 & 0,00 \\
\hline Grupo 5 & 11DIRc & 0,64 & 0,84 \\
\hline Grupo 5 & 11DIRd & 0,60 & 0,60 \\
\hline Grupo 5 & 11ESQa & 1,32 & 1,32 \\
\hline Grupo 5 & 11ESQc & 0,00 & 0,00 \\
\hline Grupo 5 & 12DIRd & 2,28 & 2,28 \\
\hline Grupo 5 & 12DIRg & 0,72 & 0,64 \\
\hline Grupo 5 & 12ESQb & 0,92 & 0,92 \\
\hline Grupo 5 & 12ESQd & 0,00 & 0,00 \\
\hline
\end{tabular}


A3. Avaliação Radiográfica - Erro do Método: Grupos 1-5, número das radiografias, primeira e segunda avaliações da perda óssea no lado direito (pressão) dos implantes osseointegráveis

\begin{tabular}{|c|c|c|c|}
\hline Grupo & $\begin{array}{l}\text { Número da } \\
\text { Radiografia }\end{array}$ & $\begin{array}{c}\text { Perda Óssea (mm) } \\
\text { Lado Direito } \\
\text { 1ํㅡ Avaliação }\end{array}$ & $\begin{array}{c}\text { Perda Óssea (mm) } \\
\text { Lado Direito } \\
\text { 2ª Avaliação }^{\text {a A }}\end{array}$ \\
\hline Grupo 1 & 1DIRa & 0,00 & 0,00 \\
\hline Grupo 1 & 3DIRa & 0,00 & 0,00 \\
\hline Grupo 1 & 5DIRa & 0,44 & 0,56 \\
\hline Grupo 1 & $5 \mathrm{DIRb}$ & 0,00 & 0,00 \\
\hline Grupo 1 & 5ESQa & 0,28 & 0,28 \\
\hline Grupo 1 & 2DIRa & 0,00 & 0,00 \\
\hline Grupo 1 & 2DIRb & 0,80 & 0,76 \\
\hline Grupo 1 & 2ESQa & 1,16 & 1,16 \\
\hline Grupo 1 & 2ESQb & 0,00 & 0,00 \\
\hline Grupo 1 & 4DIRa & 0,48 & 0,52 \\
\hline Grupo 1 & $4 \mathrm{DIRb}$ & 0,00 & 0,00 \\
\hline Grupo 1 & 4ESQa & 0,00 & 0,00 \\
\hline Grupo 2 & 4ESQb & 0,00 & 0,00 \\
\hline Grupo 2 & 6DIRa & 0,00 & 0,00 \\
\hline Grupo 2 & $6 \mathrm{DIRb}$ & 2,24 & 2,20 \\
\hline Grupo 2 & 6ESQa & 0,00 & 0,00 \\
\hline Grupo 2 & 6ESQb & 0,80 & 0,72 \\
\hline Grupo 2 & 10DIRa & 0,52 & 0,72 \\
\hline Grupo 3 & 9DIRb & 2,24 & 2,28 \\
\hline Grupo 3 & 11DIRb & 0,52 & 0,64 \\
\hline Grupo 3 & 11DIRf & 2,64 & 2,56 \\
\hline Grupo 3 & 12ESQa & 4,60 & 4,52 \\
\hline Grupo 3 & 12ESQf & 2,16 & 2,16 \\
\hline Grupo 4 & 7DIRb & 0,80 & 0,64 \\
\hline Grupo 4 & 7DIRd & 0,00 & 0,00 \\
\hline Grupo 4 & 7ESQc & 0,00 & 0,00 \\
\hline
\end{tabular}




\begin{tabular}{|c|c|c|c|}
\hline Grupo 4 & 7ESQd & 1,08 & 1,36 \\
\hline Grupo 4 & 8DIRb & 1,36 & 1,36 \\
\hline Grupo 4 & 8ESQc & 0,92 & 1,16 \\
\hline Grupo 4 & 11DIRe & 0,00 & 0,00 \\
\hline Grupo 4 & 11DIRa & 0,92 & 0,84 \\
\hline Grupo 4 & 11ESQb & 1,00 & 0,88 \\
\hline Grupo 4 & 12DIRe & 0,00 & 0,00 \\
\hline Grupo 4 & 12DIRf & 0,00 & 0,00 \\
\hline Grupo 4 & 12ESQc & 0,00 & 0,00 \\
\hline Grupo 4 & 12ESQe & 0,00 & 0,00 \\
\hline Grupo 5 & 7DIRa & 0,92 & 0,96 \\
\hline Grupo 5 & 7DIRc & 1,32 & 1,20 \\
\hline Grupo 5 & 7ESQa & 1,40 & 1,44 \\
\hline Grupo 5 & 7ESQb & 1,16 & 1,12 \\
\hline Grupo 5 & 8DIRa & 1,00 & 0,96 \\
\hline Grupo 5 & 8DIRc & 2,08 & 2,20 \\
\hline Grupo 5 & 8ESQa & 3,24 & 3,24 \\
\hline Grupo 5 & $8 \mathrm{ESQb}$ & 1,04 & 0,92 \\
\hline Grupo 5 & 9DIRa & 0,00 & 0,00 \\
\hline Grupo 5 & 9ESQb & 0,00 & 0,00 \\
\hline Grupo 5 & 9ESQc & 0,00 & 0,00 \\
\hline Grupo 5 & 11DIRc & 0,48 & 0,64 \\
\hline Grupo 5 & 11DIRd & 0,76 & 0,76 \\
\hline Grupo 5 & 11ESQa & 1,32 & 1,32 \\
\hline Grupo 5 & 11ESQc & 0,00 & 0,00 \\
\hline Grupo 5 & 12DIRd & 2,24 & 2,24 \\
\hline Grupo 5 & 12DIRg & 0,00 & 0,00 \\
\hline Grupo 5 & 12ESQb & 0,84 & 0,84 \\
\hline Grupo 5 & 12ESQd & 1,00 & 1,04 \\
\hline
\end{tabular}

